\title{
APONTAMENTOS SOBRE A OFERTA PÚBLICA PARA AQUISIÇÃO DO CONTROLE DE COMPANHIA ABERTA NA FRANÇA E NA UNIÃO EUROPEIA
}

Dissertação de mestrado

Professor Orientador:

Prof. Dr. Haroldo Malheiros Duclerc Verçosa

Faculdade de Direito

Universidade de São Paulo

São Paulo - 2013 
VIVIANE ROSSINI BERGAMASCHI ABUD

\section{APONTAMENTOS SOBRE A OFERTA PÚBLICA PARA AQUISIÇÃO DO CONTROLE DE COMPANHIA ABERTA NA FRANÇA E NA UNIÃO EUROPEIA}

Dissertação de Mestrado apresentada ao Departamento de Direito Comercial da Faculdade de Direito da Universidade de São Paulo como requisito parcial para a obtenção do grau de mestre, sob a orientação do Professor Dr. Haroldo Malheiros Duclerc Verçosa.

Faculdade de Direito

Universidade de São Paulo

São Paulo - 2013 
Data de defesa:

Resultado:

BANCA EXAMINADORA:

Prof. Dr. Haroldo M. D. Verçosa

Universidade de São Paulo

Prof. Dr.(a)

Universidade de São Paulo

Prof. Dr

Universidade 


\section{Dedico este trabalho}

Ao Daniel, por todo amor, paciência e incentivo. 


\section{AGRADECIMENTOS}

Ao Professor Haroldo Malheiros Duclerc Verçosa, pela constante orientação conferida ao longo deste trabalho.

À minha mãe, pelo apoio e incentivo incondicionais. 


\section{RESUMO}

O presente trabalho objetiva analisar a oferta pública para aquisição do controle de companhia aberta, na França e na União Europeia, sendo que, ao longo do seu desenvolvimento, serão feitas comparações pontuais com o direito brasileiro. $\mathrm{Na}$ conclusão, serão apontados aspectos relativos à disciplina da matéria analisada à luz do direito estrangeiro que possam ser adaptados e adotados pelo direito pátrio, bem como aspectos deste último que possam ser aproveitados pelo direito estrangeiro. Este estudo é relevante, em primeiro lugar, porque a internacionalização das ofertas públicas é um fenômeno que, conquanto não seja recente, se desenvolveu consideravelmente nos últimos anos, devido, sobretudo, à mundialização da economia, à globalização e à ausência de fronteira entre os mercados; em segundo lugar, em razão do desenvolvimento do mercado de capitais brasileiro, já que, com a existência de companhias que possuam estrutura acionária em que inexista um único acionista ou grupo de acionistas detentores da maioria do capital votante, tornou-se viável a ocorrência de tais operações no Brasil.

Palavras-chave: Oferta pública. Oferta pública de aquisição do controle. 


\begin{abstract}
The objective of this paper is to analyze takeover bids (or tender offers) aiming at acquiring control of public corporations in France and European Union, whereas throughout its development specific comparison with Brazilian law will be performed. As a conclusion, it will be pointed out aspects of the discussed subject matter in the light of foreign law, which can be both adapted and adopted by national law, as well as aspects of the latter which can be availed by foreign law. Firstly, this study is relevant since the internationalization of takeover bids (or tender offers) is a phenomenon that, while not new, has developed substantially in the last years, mainly due to economic globalization along with lack of boundary among markets. Secondly, on grounds of the Brazilian capital market development as it has become feasible such operations in Brazil under the existence of companies which have shareholding structure, in which there was no single shareholder or group of shareholders holding the majority of the voting capital.
\end{abstract}

Keywords: Takeover. Tender offer. 


\section{SUMÁRIO}

Capítulo 1 - Introdução .....................................................................................................12

1.1 Evolução do mercado de capitais e surgimento da oferta pública para aquisição do controle de companhia aberta

1.2 Importância e atualidade do tema .14

1.3 Breve consideração da oferta pública para aquisição de companhia aberta, na França e no Brasil .18

1.4 Delimitação do tema e divisão proposta para o trabalho 19

Capítulo 2 - Oferta pública de aquisição na França ...................................................21

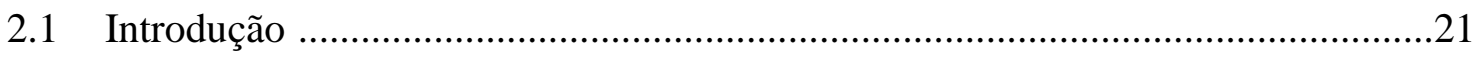

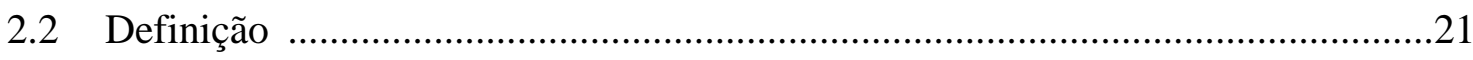

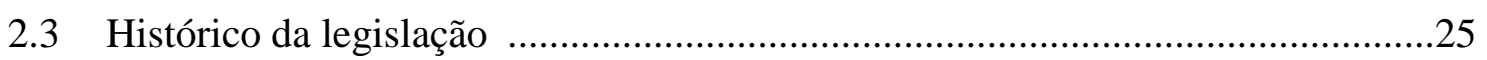

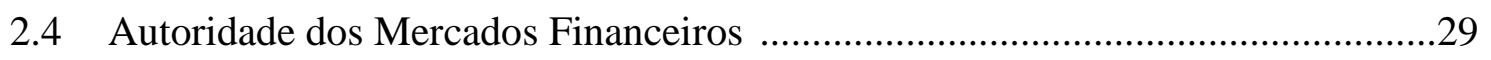

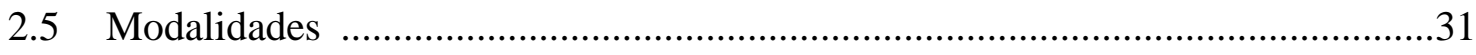

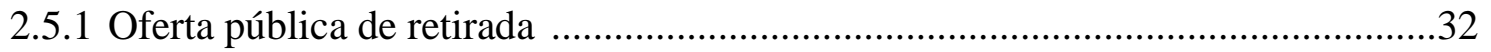

2.5.1.1 Detenção de determinado percentual dos direitos de voto ...............................33

2.5.1.1.1 Oferta pública de retirada requerida por acionista minoritário ........................34

2.5.1.1.2 Oferta pública de retirada requerida por acionista majoritário ........................36

2.5.1.2 Transformação em comandita por ações .....................................................37

2.5.1.3 Modificações jurídicas ou econômicas significativas .......................................37

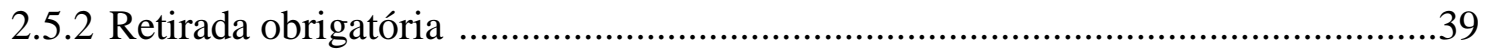

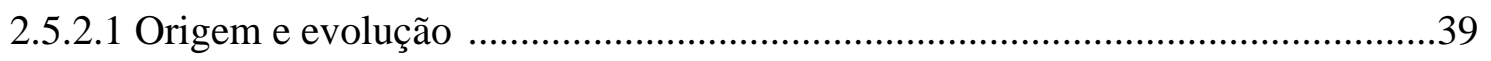

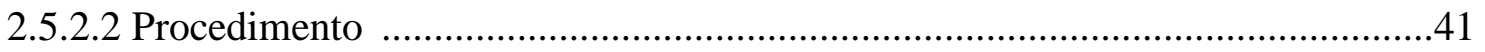

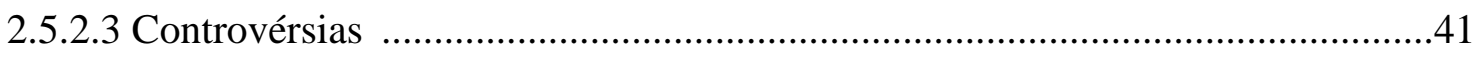

Capítulo 3 - Oferta pública para aquisição do controle de companhia aberta na

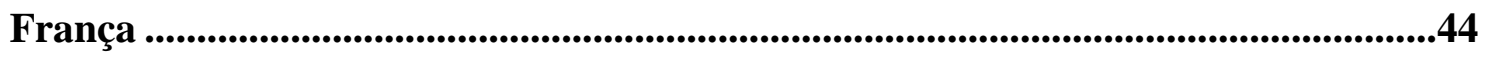

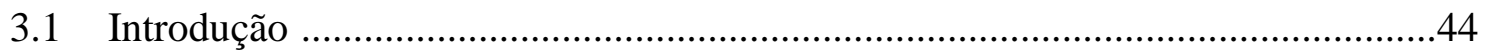

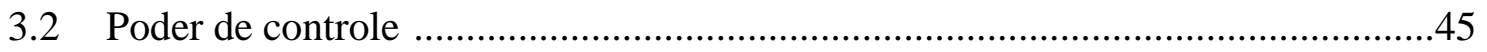

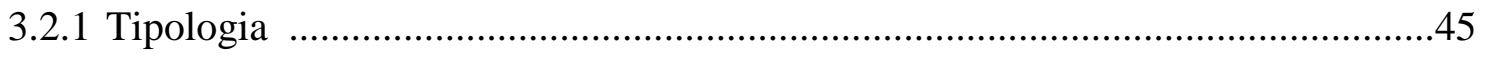

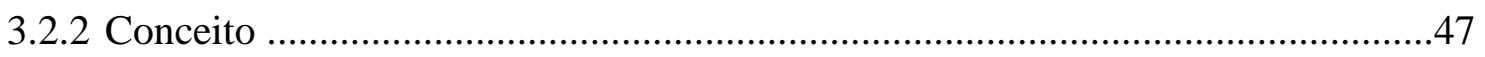


3.3 Modalidades de aquisição do controle interno de companhias abertas .50

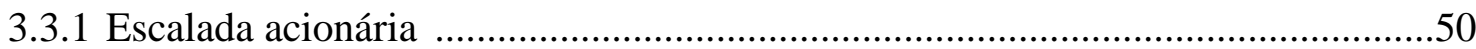

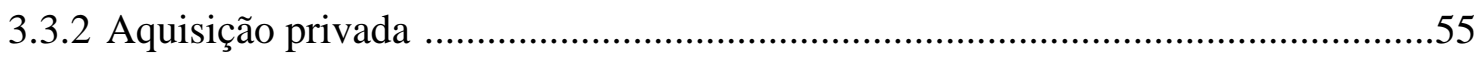

3.3.3 Oferta pública para aquisição do controle de companhia aberta ..........................58

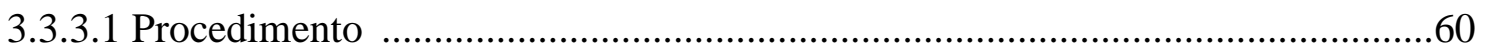

3.3.3.1.1 Da apresentação do projeto de oferta à declaração de conformidade .............61

3.3.3.1.2 Da abertura ao encerramento da oferta .......................................................66

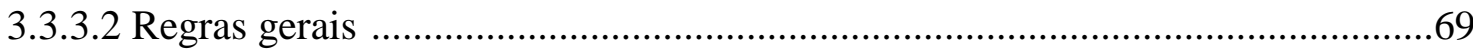

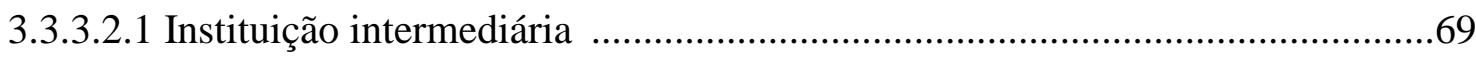

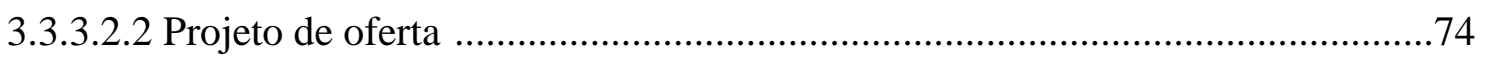

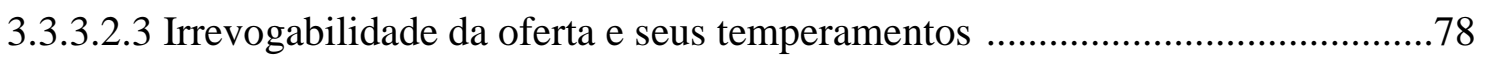

Capítulo 4 - Técnicas de defesa contra oferta pública para aquisição do controle de companhia aberta hostil na França...................................................................83

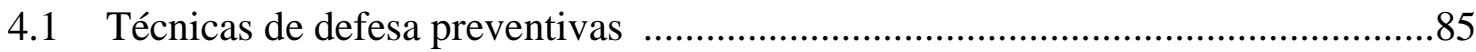

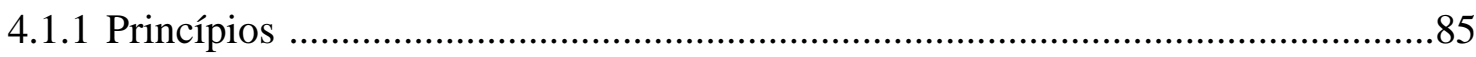

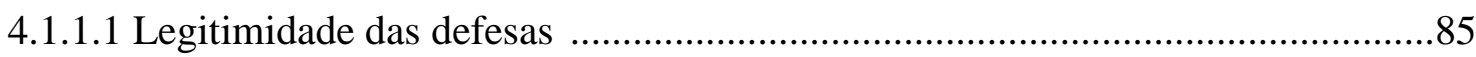

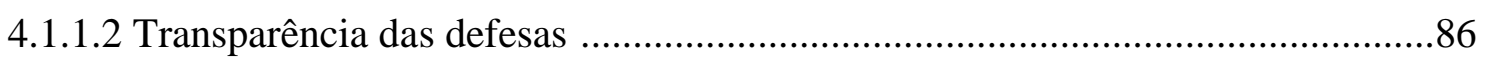

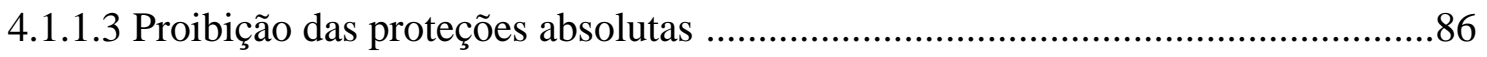

4.1.1.4 Conformidade das defesas preventivas ao interesse social ..............................87

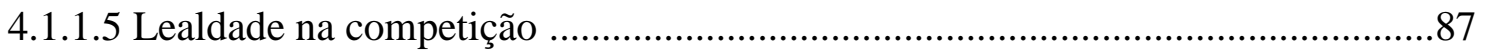

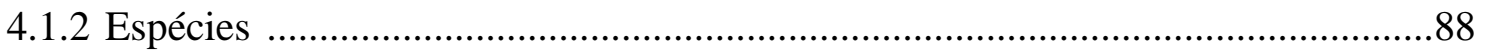

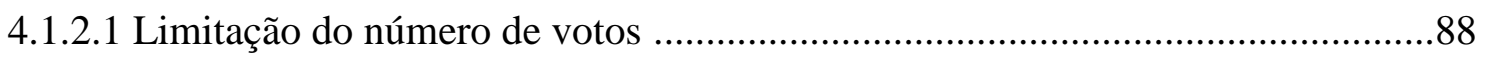

4.1.2.2 Notificação e declaração de intenção ............................................................90

4.2 Técnicas de defesa adotadas durante a oferta pública para aquisição do controle de

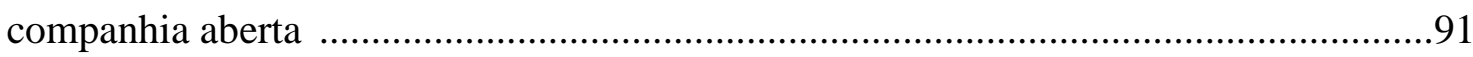

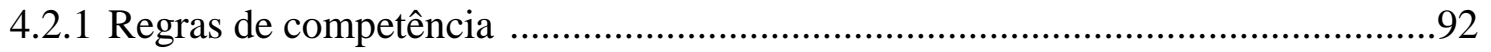

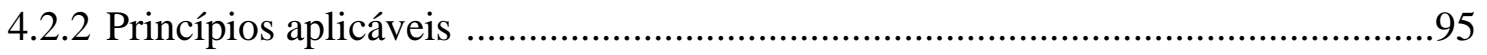

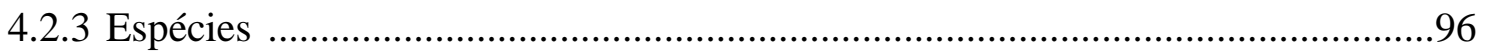

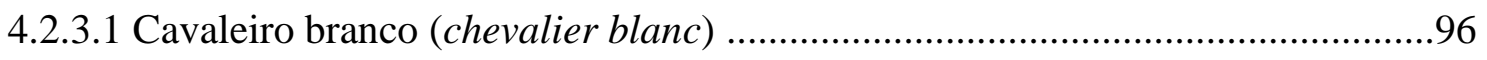

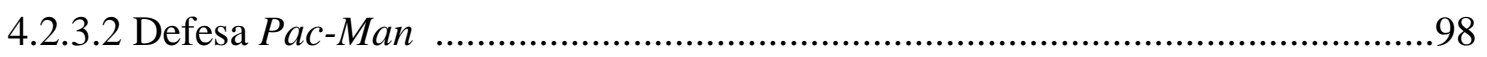

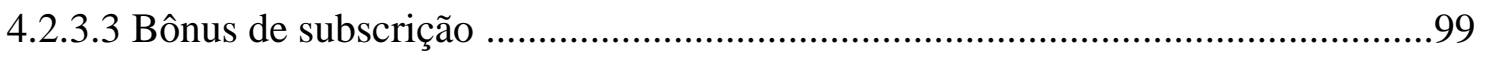


Capítulo 5 - Oferta pública para aquisição do controle de companhia aberta na União Europeia 103

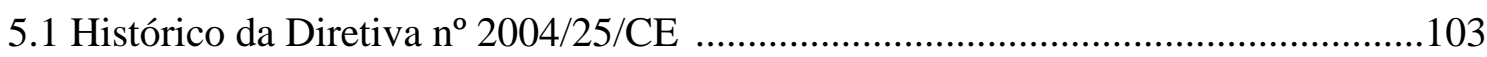

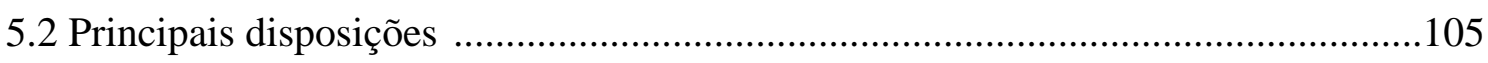

5.2.1 Autoridade competente para a supervisão da oferta e outras regras ....................105

5.2.2 Princípio da neutralidade dos administradores e outras regras ............................107

5.2.3 Não oponibilidade das restrições ("neutralização das restrições”) ......................108

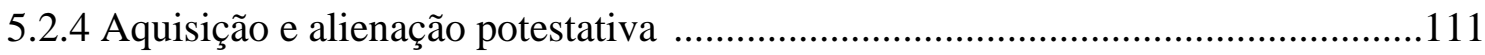

5.3 Transposição da Diretiva no 2004/25/CE, na França ............................................112

5.3.1 Autoridade de supervisão e direito aplicável ...................................................112

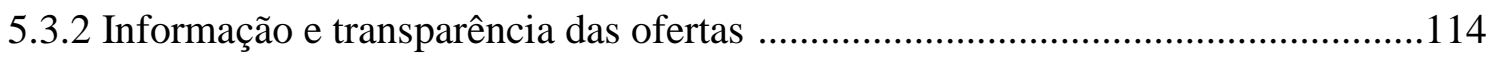

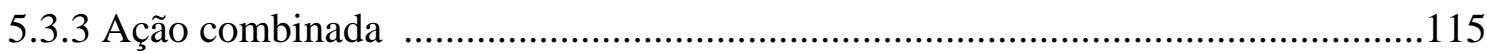

5.3.4 Técnicas de defesa contra oferta pública para aquisição do controle de companhia aberta hostil (artigos $9^{\circ}, 11$ e 12 da Diretiva $n^{\circ}$ 2004/25/CE)

Conclusão 


\section{ABREVIATURAS}

AMF

C. cass.

C. com.

C. mon. fin.

CA

CBV

CDGF

$\mathrm{CMF}$

CMT

COB

CVM

Diretiva $n^{\circ} 2004 / 25 / C E$

EUA

Instrução CVM n ${ }^{\circ}$ 361/02

Instrução CVM nº 487/10

LSA

OPA

PASF

Relatório Lepetit

comando de Jean François Lepetit

RG

UE
Autorité des Marchés Financiers

Corte de Cassação

Code de commerce

Code monétaire et financier

Corte de Apelação

Conseil des bourses de valeurs

Conseil de discipline de la gestion financière

Conseil des marchés financiers

Conseil des marchés à terme

Commission des opérations de bourse

Comissão de Valores Mobiliários

Diretiva $n^{\circ}$ 2004/25/CE do Parlamento Europeu e do

Conselho, de 21 de abril de 2004

Estados Unidos da América

Instrução CVM no 361, de 5 de março de 2002

Instrução CVM no 487, de 25 de novembro de 2010

Lei $n^{\circ}$ 6.404, de 15 de dezembro de 1976

Oferta pública para aquisição do controle de companhia aberta

Plano de ação para os serviços financeiros

Relatório elaborado por um grupo de trabalho, sob o

Règlement Général

União Europeia 


\section{CAPÍTULO 1 \\ INTRODUÇÃ̃O}

\subsection{Evolução do mercado de capitais e surgimento da oferta pública para aquisição do controle de companhia aberta.}

A evolução da economia capitalista, como ensina Fábio Konder Comparato, nos últimos 40 anos e, sobretudo, a partir da Segunda Guerra Mundial, tem sido guiada pelo fenômeno da concentração empresarial ${ }^{1}$. Assim, em diversos países do Ocidente houve uma elevação no número de fusões, incorporações e transferências do controle acionário ${ }^{2}$ de companhias, resultando no desenvolvimento e na diversificação dos mecanismos de captação de recursos, bem como no aumento das dimensões das empresas ${ }^{3}$.

Soma-se a isso a mudança de paradigma, necessária ${ }^{4}$ face à constatação de $\mathrm{A}$. Berle e G. Means a respeito da progressiva separação entre a propriedade e o controle das companhias norte-americanas ${ }^{5}$. Segundo tais autores, os administradores teriam cada vez mais o controle das macroempresas, haja vista o aumento da dispersão das ações das companhias entre diversos acionistas.

Como bem resume Erik Frederico Oioli, desapareceria, assim, a figura do "acionista controlador", propiciando o surgimento do chamado "mercado de controle

\footnotetext{
${ }^{1}$ COMPARATO, Fábio Konder. Aspectos jurídicos da macro-emprêsa. São Paulo: Revista dos Tribunais, 1970, p. 4.

${ }^{2}$ Importante ressaltar que a oferta pública para aquisição do controle de companhia aberta é uma forma de aquisição originária do poder de controle e não derivada, como ocorre nos negócios de transferência de controle. A classificação em questão é relevante em razão da regra nemo ad alium transferre potest plus quam ipse habet, bem como em razão da definição da hipótese de incidência do artigo 254-A da Lei $\mathrm{n}^{\circ}$ 6.404/76 (PEREIRA, Guilherme Döring Cunha. Alienação do poder de controle acionário. São Paulo: Saraiva, 1995 , p. 33 e OIOLI, Erik Frederico. Oferta pública de aquisição do controle de companhias abertas. São Paulo: Quartier Latin, 2010, p. 87). Com relação à distinção entre aquisição originária e derivada, afirma Erik Frederico Oioli que a primeira pode ocorrer em uma situação de inexistência de um controle estabelecido ou mesmo na existência de controle diluído, o qual não mais será exercido. São exemplos de aquisição originária, além da citada oferta pública para aquisição do controle de companhia aberta, a escalada acionária. Na segunda, pressupõe-se a preexistência do controle a ser adquirido, havendo, nas palavras de Erik Frederico Oioli, a "transferência do poder de controle". Como exemplo de aquisição derivada pode ser citada a cessão negociada do controle (OIOLI, Erik Frederico, op. cit., p. 87).

${ }^{3}$ NASCIMENTO, João Pedro Barroso do. Anotações sobre medidas defensivas à tomada de controle. São Paulo, 2010. Dissertação (Mestrado em Direito). Faculdade de Direito, Universidade de São Paulo, p. 5.

${ }^{4}$ OIOLI, Erik Frederico, op. cit., p. 31.

${ }^{5}$ BERLE JR., Adolf; MEANS, Gardiner. The modern corporation and private property. New York: Macmillan, 1940, p. 2-7.
} 
societário", porquanto, inexistindo uma pessoa que detivesse a maioria absoluta das ações com direito a voto, tornou-se mais fácil a aquisição do controle da companhia através de negociações privadas e em bolsa ou, ainda, através do lançamento de oferta pública para a aquisição de ações da companhia em número suficiente para que o controle fosse adquirido $^{6}$. Nesta situação, portanto, não se faz, mais necessária a negociação com o acionista controlador para a transferência do poder de controle, o que habitualmente envolveria o pagamento de um prêmio ao alienante ${ }^{7}$. Afirma, ainda, Erik Frederico Oioli que nesse mercado de controle societário, destacam-se as ofertas públicas para aquisição do controle de companhia aberta, "pela relevância dos seus impactos - sejam eles jurídicos, econômicos ou até mesmo políticos - sobre as companhias, seus acionistas, seus administradores, seus empregados, legisladores, órgãos reguladores e a opinião pública em geral",

Considerando que um dos pressupostos da oferta pública para aquisição do controle de companhia aberta é a dispersão acionária e que companhias brasileiras passaram a apresentar uma estrutura acionária em que inexiste um único acionista ou grupo de acionistas detentores da maioria do capital votante ${ }^{910}$, tornou-se possível a ocorrência de tais ofertas, no Brasil ${ }^{11}$.

Diante disso foram necessárias mudanças na Instrução CVM n ${ }^{\circ} 361$, de 5 de março de 2002 (Instrução CVM n n $^{\text {361/02) }}{ }^{12}$, mudanças essas operadas, principalmente, pela Instrução CVM nº 487, de 25 de novembro de 2010 (Instrução CVM n 487/10). As mudanças em questão decorreram, sobretudo, da necessidade de adaptação das regras

\footnotetext{
${ }^{6}$ OIOLI, Erik Frederico, op. cit., p. 19.

${ }^{7}$ Idem, ibidem.

${ }^{8}$ Idem, p. 19-20.

9 A reportagem do Jornal Valor Econômico, intitulada "À espera de uma oferta", aborda o assunto, ao dizer que "o número de pulverizadas, em termos absolutos, ainda é pequeno. Mas representa avanço significativo nos últimos dez anos. De acordo com dados da BM\&FBovespa, são exatas 47 empresas com mais de $51 \%$ das ações circulando em bolsa de um total de 125 no Novo Mercado - ou 37,5\%" (VALENTI, Graziella. À espera de uma oferta. Valor Econômico - EU\&Investimentos, 17 de agosto de 2011).

${ }^{10}$ OIOLI, Erik Frederico, op. cit., p. 21.

${ }^{11}$ Em 2006, houve a tentativa de aquisição do poder de controle da Perdigão S.A. pela Sadia S.A., mas a oferta pública para aquisição do controle foi rejeitada pelos acionistas. A Telecomunicações de São Paulo S.A. (Telesp) publicou, em 7 de outubro de 2009, edital de oferta pública de ações para aquisição do controle da GVT (Holding) S.A. Conforme edital, datado de 15 de abril de 2011, a MMX Mineração Metálicos S.A. lançou uma OPA para a aquisição do controle da PortX Operações Portuárias S.A.

${ }^{12}$ A Instrução em questão foi, ainda, alterada pela Instrução CVM no 492, de 23 de fevereiro de 2011.
} 
sobre a oferta pública para a aquisição do controle de companhia aberta, num cenário em que tais ofertas tendem a se tornar mais presentes ${ }^{13}$.

Conquanto o foco deste estudo seja a análise, na França e na União Europeia (UE), das ofertas públicas para aquisição do controle de companhia aberta, o desenvolvimento do mercado de capitais brasileiro acima descrito é relevante, visto que, além de tornar o presente trabalho mais útil, contribui, por exemplo, para que possíveis soluções existentes no direito estrangeiro possam ser adaptadas e aplicadas no direito pátrio. Por outro lado, não se deve excluir, considerando a importância do mercado de capitais brasileiro, a possibilidade de o direito francês adotar soluções previstas pelo direito brasileiro.

\subsection{Importância e atualidade do tema.}

O estudo em questão é importante por diversos motivos, conforme a seguir exposto. Primeiramente, na UE, sob a impulsão das instâncias comunitárias, principalmente da Comissão Europeia, houve a aceleração de reformas referentes à harmonização da regulamentação dos mercados financeiros. A fim de atingir rapidamente o objetivo de integração econômica e monetária determinado pela UE, objetivo esse que supunha necessariamente a construção de um mercado financeiro integrado e que respondesse às exigências de seus principais operadores, foi fixado um programa de ação específico, em 1999, no âmbito do plano de ação para os serviços financeiros (PASF) ${ }^{14}$.

Além disso, com o intuito de diminuir as disparidades existentes entre os direitos dos diferentes Estados-Membros na matéria, concebidas como obstáculos ao bom funcionamento do mercado financeiro da UE, foi programada a adoção de 42 medidas legislativas ${ }^{15}$. Uma delas consistia na adoção da Diretiva relativa às ofertas públicas de aquisição, a respeito da qual um consenso foi encontrado após quase 15 anos de negociação, tendo sido ela considerada, desde a origem, a base do PASF. A Diretiva $n^{\circ}$ 2004/25/CE do Parlamento Europeu e do Conselho da União Europeia, de 21 de abril de

\footnotetext{
${ }^{13}$ Disponível em < http://www.cvm.gov.br/port/infos/Comunicado\%20487.asp $>$. Acesso em: 19.04.11.

${ }^{14}$ KLOEPFER-PELĖSE, Martine. Contribution à l'étude des offres publiques d'acquisition en droit français et américain: de l'attribution du pouvoir de décision au regard de l'analyse économique du droit. Paris, 2007. Tese (Doutorado em direito). Université Paris I, p. 7.

${ }^{15}$ Idem, ibidem.
} 
2004 (Diretiva n 2004/25/CE), contribuiria, aos olhos das instâncias europeias, para a facilitação das reestruturações societárias, auxiliando, ainda, a economia da Europa a se tornar mais competitiva ${ }^{16}$.

As ofertas públicas para aquisição do controle tiveram origem provavelmente na Inglaterra, onde são reguladas desde o Companies Act, datado de 1929, e conhecidas como takeover bids. Apesar disso, apenas a partir de 1950 passaram a ter notoriedade na Inglaterra, tornando-se muito comuns, a partir da década de 1960, nos EUA, onde são conhecidas como tender offers ${ }^{17}$.

Nota-se, desde a década de 1990, um rápido desenvolvimento do mercado de capitais europeu, segundo aponta Erik Frederico Oioli ${ }^{18}$. O número de ofertas "hostis"19 também tem aumentado consideravelmente. Entre 1986 e 1999, o número de tais operações (ofertas "hostis") envolvendo companhias europeias aumentou de $15 \%$ para $43 \%{ }^{20}$. Aponta o autor em questão que essas mudanças se devem "menos a mudanças estruturais que a políticas" 21 .

\footnotetext{
${ }^{16}$ Nesse sentido, afirmou o Comissário europeu, quando da apresentação pela Comissão Europeia, da sua nova proposta de regras comuns para as ofertas públicas de aquisição: "Le but de cette proposition est de permettre de réaliser des OPA dans l'UE dans les meilleures conditions pour toutes les parties concernées. Cette directive a toujours constitué une étape essentielle dans l'intégration complète du marché européen des capitaux d'ici à 2005. C'est un élément clé dans le projet de l'Union européenne de faire de l'Europe la première économie mondiale d'ici à 2010" (Disponível em

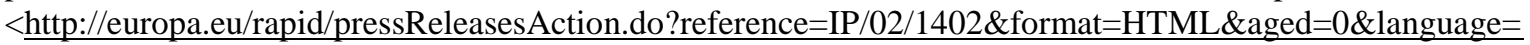
FR\&guiLanguage=en>. Acesso em: 18.04.11). Tradução livre: "O objetivo desta proposta é permitir que as OPA ocorram na União Europeia nas melhores condições possíveis, com relação a todas as partes interessadas. A diretiva em questão sempre constituiu uma etapa essencial para a integração completa do mercado de capitais europeu até 2005. Trata-se de um elemento fundamental no projeto da União Europeia relativo a tornar a Europa a primeira economia mundial até 2010".

${ }^{17}$ OIOLI, Erik Frederico, op. cit., p. 91.

${ }^{18}$ Idem, ibidem.

${ }^{19}$ Na França, a oferta pública para aquisição do controle de companhia aberta hostil é aquela iniciada sem o acordo dos administradores da companhia visada (COHEN, Daniel. Vers la fin des offres publiques hostiles? In: Mélanges offerts à Paul Didier: études de droit privé. Economica, 2008, p. 125). Como bem explica Erik Frederico Oioli, à luz do direito brasileiro, as ofertas públicas hostis são aquelas desaprovadas pelos administradores e pelo acionista controlador da companhia, de acordo com a lei, a qual lhes impõe direitos e responsabilidades que jusficam referida posição. Dessa maneira, a desaprovação não pode se basear, por exemplo, em meros interesses particulares. Por fim, o fato de a oferta ser hostil, ou seja, desaprovada, justifica a adoção das chamadas técnicas de defesa, a serem analisadas no Capítulo 4 (OIOLI, Erik Frederico, op. cit., p. 94).

${ }^{20}$ Idem, p. 49-50

${ }^{21}$ Idem, ibidem.
} 


\section{$\mathrm{Na}$ França $^{22}$, conforme aponta Daniel Cohen $^{23}$, a primeira importante oferta}

pública para aquisição do controle de companhia ocorreu em 1968 e foi uma operação

hostil: trata-se da oferta pública lançada pela Boussois-Souchon-Neuvesel sobre SaintGobain $^{24}$, estabelecendo, para alguns, em uma época na qual a legislação apresentava

22 Bruno Husson revela a considerável diferença entre o número de ofertas públicas para aquisição do controle de companhia aberta ocorridas na França e nos EUA, ao longo do período correspondente a 1975 e 1984. Aponta, contudo, o autor, em seu livro de 1987, que o panorama pouco favorável às tentativas de tomada de controle passava por modificações. Nesse sentido, afirma Bruno Husson: "A la différence des États-Unis où les mergers, tender offers, buy-outs et autres opérations de restructuration du capital des entreprises animent quotidiennement le marché, la France offre le paysage d'un marché boursier le plus souvent paisible, mais parfois brutalement réveillé par une tentative de prise de contrôle, dont l'effet perturbateur est à la mesure du caractère exceptionnel de l'événement. La comparaison du nombre d'offres publiques d'achat réalisés dans les deux pays est à cet égard très significative. Ainsi, au cours de la période 1975-1984, le marché français a connu le lancement de 42 opérations (dont seulement une en 1983 et même aucune en 1982 e 1984), tandis que dans le même temps le marché américain enregistrait quelque 1300 opérations, soit un rythme annuel moyen plus de trente fois supérieur à la cadence française. Les raisons de cette relative atonie du marché français sont multiples. Conséquence directe du poids important du secteur public et parapublic dans l'économie, la faible proportion des entreprises présentes sur le marché boursier constitue l'une des toutes premières explications (...). A ces facteurs objectifs s'ajoutent enfin des considérations d'ordre socioculturel. Comme en témoigne la vigueur du combat idéologique qui resurgit à l'occasion de chaque échéance électorale de dimension nationale, les principes de fonctionnement de l'économie de marché ne sont pas encore profondément ancrés dans les mentalités, ni même communément admis. En outre, les dirigeants d'entreprises constituent en France un groupe relativement homogène et solidaire. Aussi n'est-il guère surprenant de constater que la bataille pour le pouvoir économique se déroule rarement au grand jour sur le marché boursier, (...). Un tel environnement, peu favorable au développement des tentatives de prises de contrôle, est cependant en train de se modifier en profondeur et plusieurs indices, apparus au cours des trois dernières années, sont à cet égard particulièrement révélateurs" (HUSSON, Bruno. La prise de contrôle d'entreprises. Paris: Presses Universitaires de France, 1987, p. 11). Tradução livre: "Diferentemente dos Estados Unidos, onde os mergers, tender offers, buy-outs e outras operações de reestruturação do capital das empresas animam diariamente o mercado, a França oferece uma situação na qual o mercado de capitais se revela, na maioria das vezes, tranquilo. No entanto, em alguns casos, referido mercado é brutalmente reanimado por uma tentativa de tomada de controle cujo efeito perturbador é proporcional ao caráter excepcional do acontecimento. A comparação do número de ofertas públicas de aquisição realizadas nos dois países é muito significativa. Assim, no período correspondente a 1975-1984, houve, na França, o registro de 42 operações, sendo apenas uma em 1983 e nenhuma em 1983 e 1984. Enquanto isso, no mesmo período, no mercado americano, houve o registro de, aproximadamente, 1300 operações, ou seja, um ritmo anual médio mais de trinta vezes superior à frequência ocorrida na França. As razões dessa relativa atonia do mercado francês são múltiplas. Consequência direta do peso importante do setor público na economia, a pequena proporção das empresas presentes no mercado constitui uma das primeiras explicações (...). A tais fatores objetivos somam-se, enfim, considerações de ordem sociocultural. Como evidenciado pelo vigor do combate ideológico que ressurge a cada eleição de dimensão nacional, os princípios do funcionamento da economia de mercado não foram ainda fixados nas mentalidades, nem mesmo comumente aceitos. Ademais, os administradores das empresas constituem, na França, um grupo relativamente homogêneo e solidário. É pouco surpreendente, pois, constatar que, para o poder econômico, a batalha raramente ocorre abertamente no mercado de capitais. (...). O panorama em questão, pouco favorável ao desenvolvimento das tentativas de tomada de controle, está se modificando profundamente e vários indícios o demonstram, nos últimos três anos".

${ }^{23}$ COHEN, Daniel, op. cit., p. 125.

${ }^{24}$ Tratou-se, na realidade, como lembra Fábio Konder Comparato, de uma oferta pública de troca de ações da Saint-Gobain por debêntures conversíveis em ações da Société Boussois-Souchon-Neuvesel (COMPARATO, Fábio Konder, op. cit., p. 38). Como afirma Philippe Merle, a tentativa de aquisição do controle fracassou e, nas palavras do citado autor, “(...) il était apparu à l'époque qu'une OPA ne pouvait pratiquement réussir qu'avec l'accord des dirigeants de la société convoitée” (MERLE, Philippe. Droit commercial: sociétés commerciales. 9. ed. Paris: Dalloz, 2003, p. 775). Tradução livre: “(...) pareceu, na época, que uma OPA apenas poderia ser bem sucedida com o consentimento dos administradores da companhia visada". 
lacunas, o "triunfo do capitalismo selvagem" 25 . A referida tentativa de aquisição do controle influenciou consideravelmente os comportamentos, haja vista a possibilidade de se lançar uma oferta pública hostil para aquisição do controle de companhia aberta, assim como a possibilidade de os administradores se organizarem e se defenderem e a de os acionistas decidirem considerando os diferentes interesses em questão. A partir disso, fazia-se necessária a intervenção do Poder Público, a fim de disciplinar as ofertas públicas $^{26}$.

Diante do acima exposto, o estudo da oferta pública para aquisição do controle de companhia aberta na França e na UE é importante, já que a internacionalização das ofertas públicas é um fenômeno que, apesar de não ser recente, se desenvolveu consideravelmente nos últimos anos, em razão da mundialização da economia, da globalização e da ausência de fronteiras dos mercados financeiros, nos quais intervêm operadores de todas as nacionalidades ${ }^{27}$.

\footnotetext{
${ }^{25}$ Expressão usada por M. Trochu (TROCHU, M. apud COHEN, Daniel, op. cit., p. 125). A respeito do "capitalismo selvagem", afirma Fábio Konder Comparato: "Já se disse que a take-over bid reabriu uma nova era do 'capitalismo selvagem', e haverá sem dúvida quem identifique na operação uma espécie de guerra às avessas, em que os grandes combatem e os pequenos aproveitam. É preciso não esquecer, porém, que a imoralidade está no centro de tôda guerra, e que mesmo esta, embora 'às avessas', não faz exceção à regra. De onde surgem, afinal, os recursos para que diretorias rivais sustentem dispendiosíssima campanha publicitária na imprensa, no cinema, no rádio e na televisão, e manipulem ações da própria sociedade por interposta pessoa? Como é possível aumentar voluntàriamente de $60 \%$ a remuneração normal do capital, de um exercício para outro, quando aumentos muito inferiores de salário só se obtêm à custa de greves, processos judiciais ou injunções administrativas? Se as take-over bids não resolverem o problema da tecnocracia oligárquica, na grande emprêsa, pelo menos o expuseram, sem disfarces, à luz do dia" (COMPARATO, Fábio Konder, op. cit., p. 41).

${ }^{26}$ COHEN, Daniel, op. cit., p. 125.

${ }^{27}$ Assim afirma Daniel Cohen: "L'internalisation des offres publiques est un phénomène qui sans être spécifiquement récent a connu ces dernières années un développement considérable. Elle s'explique aisément par la mondialisation de l'économie, la globalisation et l'absence de frontières des marchés financiers sur lesquels interviennent désormais des opérateurs de toutes nationalités, de toute nature (opérateurs publics ou émanations d'États, opérateurs privés industriels, fonds d'investissements, etc.) à la recherche de profits plus diversifiés, de relais de croissance et d'investissements rentables. Les offres ne sont plus lancées nécessairement dans le seul contexte national mais font intervenir plus fréquemment des opérateurs étrangers, l'offre devenant alors internationale" (Idem, p. 127). Tradução livre: "A internacionalização das ofertas públicas é um fenômeno que, apesar de não ser recente, conheceu nesses últimos anos um desenvolvimento considerável. Mencionado fenômeno se explica facilmente pela mundialização da economia, pela globalização e pela ausência de fronteiras entre os mercados financeiros nos quais intervêm operadores de todas as nacionalidades e de toda natureza (operadores públicos, fundos de investimentos, etc.) à procura de lucros diversificados, de fontes de crescimento e de investimentos rentáveis. As ofertas não são mais necessariamente lançadas em um contexto unicamente nacional. Há, frequentemente, a participação de operadores estrangeiros, sendo, neste caso, a oferta internacional".
} 


\subsection{Breve consideração da oferta pública para aquisição do controle de companhia aberta, na França e no Brasil.}

No Brasil e na França, a oferta pública para aquisição do controle de companhia aberta, ou seja, aquela mediante a qual o ofertante deseja assumir o controle de certa companhia, que não possua um acionista ou grupo controlador previamente definido ${ }^{28}$, é, respectivamente, disciplinada ${ }^{29}$ pela Lei $\mathrm{n}^{\mathrm{o}}$ 6.404, de 15 de dezembro de 1976 (LSA), nos artigos 257 a 263, e, sobretudo, nos artigos L. 433-1 a L. 433-3 do Code monétaire et financier (C. mon. fin.), bem como nos artigos 231-1 e seguintes do Règlement Général (RG) da Autorité des Marchés Financiers (AMF).

As principais diferenças, que serão abordadas ao longo deste estudo, se referem, primeiramente, ao fato de que, no Brasil, a oferta pública para aquisição do controle de companhia aberta deve ter por objeto ações com direito a voto em número suficiente para garantir o controle da companhia (art. 257, §2º , da LSA). Já, na França o objeto da oferta pública para aquisição do controle de companhia aberta é mais amplo, pois nele compreende, além das ações com ou sem direito a voto, outros valores mobiliários, tais como aqueles conversíveis em ações ( $v \cdot g$. debêntures conversíveis em ações) ${ }^{30}$.

Importante notar que, na França, as ofertas públicas para aquisição do controle de companhia aberta surgiram como um mecanismo desenvolvido pela prática a fim de tomar o controle de uma companhia aberta com dispersão acionária ${ }^{31}$. O Poder Púbico se inspirou

\footnotetext{
${ }^{28}$ PRADO, Roberta Nioac. Oferta pública de ações obrigatória nas S.A. São Paulo: Quartier Latin, 2005, p. 43.

${ }^{29}$ Referida oferta pública para aquisição do controle de companhia aberta deve, ainda, observar, no que lhe for aplicável, as disposições da Instrução CVM nº 361/02.

${ }^{30}$ Art. 231-6 do RG da AMF.

${ }^{31}$ Entende Alain Viandier, conforme a seguir indicado, que, sob o ponto de vista econômico, a oferta pública de aquisição é um modo de concentração das empresas, constituindo essencialmente uma forma de aquisição do controle de sociedades: "Pour l'économiste, l'offre publique qu'elle soit d'achat ou d'échange, est un mode de concentration des entreprises. De ce point de vue, elle est à ranger à côté de la fusion ou de la cession d'entreprise. Elle permet, dans l'idéal, par une recomposition de l'actionnariat, la constitution d'entreprises puissantes ayant atteint une taille critique, condition de l'indépendance et de la survie ... C'est donc essentiellement une forme de prise de contrôle. La prise de contrôle permet de maîtriser l'activité de la société dominée, d'accéder à une technologie, de conquérir des parts de marché, d'étendre une gamme de produits, de s'approprier des actifs spécifiques (réserves pétrolières, autorisations d'émettre, droits de trafic aérien), de parfaire une implantation entravée par une réglementation archaïque (grande distribution)" (VIANDIER, Alain. OPA, OPE et autres offres publiques. 4. ed. Paris: Francis Lefebvre, 2010, p. 6). Tradução livre: "Para o economista, a oferta pública, seja de compra ou de permuta, é um modo de concentração das empresas. Desse ponto de vista, ela se encontra ao lado da fusão e da cessão de empresa. A oferta pública permite, idealmente, por meio da recomposição dos acionistas, a constituição de empresas poderosas, condição de sua independência e sobrevivência ... Trata-se, pois, essencialmente de uma forma de
} 
de tal técnica para, em seguida, desenvolver outras ofertas públicas, as quais não serão o foco deste estudo ${ }^{32}$.

Embora a sigla OPA seja usada tanto no Brasil como na França para designar diferentes tipos de ofertas públicas, neste trabalho tal sigla será empregada para se referir à oferta pública para aquisição do controle de companhia aberta. A expressão OPA $a$ posteriori será usada para designar tanto a oferta pública de aquisição prevista no artigo 254-A da LSA como aquela prevista no artigo L. 433-3, I, do C. mon. fin.

\subsection{Delimitação do tema e divisão proposta para o trabalho.}

Vale ressaltar que não foram considerados neste estudo aspectos relacionados a outros ramos do direito, tais como o direito penal e o direito tributário.

Para melhor compreensão do tema, no Capítulo 2 será definida a oferta pública de aquisição, na França, passando pelo histórico da legislação, pela análise da AMF, chegando ao breve estudo de algumas modalidades de ofertas públicas de aquisição existentes.

No Capítulo 3, será feito o exame da OPA, na França. Antes disso, contudo, serão brevemente estudados o poder de controle, bem como as modalidades de aquisição do controle interno de companhias abertas.

Após (Capítulo 4), serão analisadas as técnicas de defesa contra OPA hostil, haja vista a necessidade, para uma análise completa do tema ${ }^{33}$, do estudo de tais técnicas de defesa, utilizadas pelos administradores ou acionistas da companhia visada ${ }^{34}$, a fim de impedir o sucesso da oferta.

tomada de controle, a qual permite fiscalizar a atividade da sociedade dominada, ter acesso à tecnologia, ganhar espaço no mercado, desenvolver uma gama de produtos, apropriar-se de ativos específicos (reservas petrolíferas, autorização de emitir, direitos de tráfego aéreo), concluir um projeto entravado por uma regulamentação arcaica (varejo)".

${ }_{32}$ DIDIER, Paul; DIDIER, Philippe. Droit commercial: les sociétés commerciales. t. 2. Paris: Economica, 2011, p. 1072.

${ }^{33}$ OIOLI, Erik Frederico, op. cit., p. 22.

${ }^{34}$ Trata-se da companhia aberta emissora das ações visadas na OPA, também denominada, neste estudo, de "companhia objeto". 
No Capítulo 5, destinado à OPA na UE, serão examinados os seguintes pontos: o histórico da Diretiva $n^{\circ}$ 2004/25/CE, as principais regras, bem como a transposição da mencionada Diretiva, na França.

Finalmente, serão tecidas considerações conclusivas. 


\section{CAPÍTULO 2 \\ OFERTA PÚBLICA DE AQUISIÇÃO NA FRANÇA}

\subsection{Introdução.}

Conquanto o presente trabalho tenha como foco o estudo da OPA na França e na EU, para a melhor compreensão do instituto, faz-se necessário que, de modo breve, seja definida a oferta pública de aquisição, no direito francês, seja analisado o histórico da legislação relacionada à oferta pública de aquisição, sejam examinados alguns aspectos relativos à AMF e, finalmente, sejam brevemente descritas algumas das modalidades de oferta pública existentes do referido instituto.

É preciso ter em mente, conforme acima mencionado, que as ofertas públicas de aquisição surgiram como um meio construído pela prática para se adquirir o controle de companhia de capital disperso. Baseados e inspirados na mencionada operação, foram desenvolvidos outros mecanismos, conforme o objetivo almejado. Diante disso, como se verá adiante (item 2.3), a disciplina das ofertas públicas de aquisição, no início correspondia àquela das OPA, havendo, após, a criação de outras ofertas.

\subsection{Definição.}

Faz-se necessário definir o que se entende, no direito francês, por oferta pública de aquisição e, após, detalhar, de forma breve, alguns dos elementos de tal definição, mesmo que a respeito deles sejam tecidas considerações no decorrer deste estudo.

Entende Alain Viandier que oferta pública de aquisição constitui um compromisso unilateral, irrevogável e público de adquirir os valores mobiliários ${ }^{35}$ de uma companhia aberta $^{36}$. Primeiramente, por "compromisso unilateral" se entende uma oferta de contratar. No direito francês, a oferta pública, em princípio, resulta de uma decisão espontânea do

${ }^{35}$ BONNEAU, Thierry; DRUMMOND, France. Droit des marchés financiers. 3. ed. Paris: Economica, 2010, p. 871.

${ }^{36}$ VIANDIER, Alain, op. cit., p. 6. 
ofertante, podendo, contudo, resultar de uma obrigação, quando, por exemplo, for atingido mais de $30 \%$ do capital social ou dos direitos de voto ${ }^{37}$.

Sobre o fato de ser irrevogável, vale ressaltar que o ofertante não dispõe, em princípio, do direito de desistir da oferta, desde que esta tenha sido julgada pela AMF como estando em consonância com as disposições legislativas e regulamentares ${ }^{38}$.

Com relação à expressão "compromisso de adquirir", é necessário ter em mente que a oferta pública pode ser de compra, quando o pagamento proposto deva ser realizado em moeda corrente ou de permuta, quando o pagamento proposto deva ser realizado em valores mobiliários de emissão de companhia aberta ${ }^{39}$, assim como ocorre no direito brasileiro. Importante notar que pode a oferta pública ser mista, ou seja, o pagamento proposto será realizado parte em dinheiro e parte em valores mobiliários, conforme será analisado no Capítulo $3^{40}$.

No que tange aos valores mobiliários, primeiramente, faz-se necessária uma breve exposição acerca de sua noção, no direito francês.

Classicamente, à luz do direito francês, os effets de commerce e as valeurs mobilières são integrantes do grupo maior relativo aos títulos negociáveis. Nessa concepção, os doutrinadores franceses se preocupavam menos em definir a categoria maior dos títulos negociáveis do que a das subespécies ${ }^{41}$.

Os effets de commerce se diferenciam das valeurs mobilières, pois os primeiros são títulos que não fazem parte de uma emissão global, já que são emitidos individualmente. Além disso, são representativos de crédito a curto prazo e servem como meio de pagamento. De outra forma, as valeurs mobilières são emitidas em massa e

\footnotetext{
${ }^{37}$ VIANDIER, Alain, op. cit., p. 6. Ver item 3.3.1.

${ }^{38}$ Idem, p. 7.

${ }^{39}$ Idem, ibidem.

${ }^{40}$ Nesse sentido afirma Paul Didier: “(...) Eventuellement, ces rémunérations peuvent être combinées. Ainsi dans le cadre d'une offre mixte, l'actionnaire de la cible reçoit à la fois des titres et de l'argent" (DIDIER, Paul; DIDIER, Philippe, op. cit., p. 1087). Tradução livre: “(...) Eventualmente, tais remunerações podem ser combinadas. É o que ocorre no caso de uma oferta mista, o acionista da companhia visada recebe valores mobiliários e dinheiro".

${ }^{41}$ MATTOS FILHO, Ary Oswald. O conceito de valor mobiliário. Revista de administração de empresas, Rio de Janeiro, n. 25, 1985, p. 41.
} 
fungíveis, podendo conferir ao seu titular direito de participação social ou de crédito a longo prazo ${ }^{42}$.

A categoria dos títulos negociáveis continua a existir, mas importa notar que o direito francês passou, no ano de 2009, por uma importante reforma, no que tange aos valores mobiliários. Citada reforma se deu com a Ordonnance $\mathrm{n}^{\circ} 2009-15$, de 8 de janeiro de $2009^{43}$. A categoria dos instrumentos financeiros foi dividida em dois subgrupos - a saber: os títulos financeiros e os contratos financeiros. A mudança em questão foi positiva, no que se refere ao aspecto formal, já que sistematizou no C. mon. fin. o conjunto de disposições a respeito das operações sobre tais instrumentos financeiros ${ }^{44}$.

Os valores mobiliários são definidos como títulos financeiros, segundo o artigo L. 211-1 do C. mon. fin., e conferem direitos idênticos por categoria (art. L. 228-1 do Code de commerce - C. com.). Dispõe mencionado artigo L. 211-1 do C. mon. fin. que os títulos financeiros são títulos de capital emitidos pelas sociedades anônimas, títulos de crédito, com exclusão dos effets de commerce e dos bons de caisse, as partes ou ações dos organismos de investimento coletivo.

O que se critica na mencionada reforma é o fato de que definir valor mobiliário a partir da noção de títulos financeiros seria, de certa forma, negar sua particularidade. Thierry Bonneau, por meio de indagações, critica a reforma realizada:

\footnotetext{
"Fondre les valeurs mobilières dans les titres financiers, ne serait-ce pas nier la spécificité de ces instruments, assimiler les actions et obligations à de simples biens négociables sur un marché, oublier leur particularité - cette fonction de financement à long terme de leur émetteur - qui fait de leurs propriétaires non pas seulement des consommateurs de biens financiers mais des partenaires de l'entreprise qui les émet. L'une des leçons de la crise n'est-elle pas que c'est
}

42 ALVARES, Jefferson Siqueira de Brito. O atual conceito de valor mobiliário. Revista de Direito Mercantil, Industrial, Econômico e Financeiro, São Paulo, v. 142, 2006, p. 208-209.

${ }^{43}$ A Lei no 2008-776, de 4 de agosto de 2008, chamada de loi de modernisation de l'économie, autorizou o governo a reformar a matéria em questão, a fim de torná-la mais atrativa.

${ }^{44}$ As lições de Thierry Bonneau são nesse sentido: "Le droit des titres se présente sous la forme d'un corpus cohérent et aisément accessible et le législateur français dispose ainsi d'un outil qu'il peut promouvoir comme modèle alternatif au droit américain pour peser dans les négociations internationales" (BONNEAU, Thierry; DRUMMOND, France, op. cit., p. 90). Tradução livre: "O direito dos valores mobiliários é apresentado sob a forma de um corpus coerente e facilmente acessível, dispondo assim o legislador francês de uma ferramenta, que pode ser promovida como modelo alternativo ao direito americano, nas negociações internacionais". 
l'inverse qu'il convient de rechercher? Plutôt que de supprimer la notion, ne faut-il s'attacher à la réhabiliter, à la nourrir, en travaillant sur la spécificité de ces titres et en recherchent comment traduire, dans une définition ou un régime spécifique, cette fonction très particulière de financement à long terme de l'émetteur?"45.

Tendo em vista que os valores mobiliários não possuem como única particularidade a questão do crédito a longo prazo, melhor seria que as especificidades dos mencionados títulos fossem exploradas, criando-lhes um regime específico.

Como mencionado na Introdução deste trabalho, o objeto da OPA, à luz do direito francês, é mais amplo, se comparado com o direito brasileiro, pois é possível que ele compreenda, além das ações com ou sem direito a voto, outros valores mobiliários (v.g. debêntures conversíveis em ações). Nesse sentido é o entendimento de Alain Viandier sobre o assunto:

\begin{abstract}
“L'offre publique, parce qu'elle est un instrument de prise de contrôle, vise principalement des titres conférant un droit de vote, ce sont donc les actions ordinaires ou de préférence - qui seront ramassées. Mais d'autres titres ont pu être émis par la société convoitée, qui donnent accès au capital (C. Com., art. L. 228-91). Ce sont les obligations convertibles, (...), les bons autonomes de souscription et toutes les variétés résultant des hybridations inventées par les praticiens" $" 46$.
\end{abstract}

Apesar disso, o termo empregado neste estudo para se referir ao objeto da OPA, no direito francês, é "ações".

\footnotetext{
${ }^{45}$ BONNEAU, Thierry; DRUMMOND, France, op. cit., p. 93. Tradução livre: "Fundir os valores mobiliários nos títulos financeiros não seria negar a especificidade desses instrumentos, assim como comparar as ações e debêntures com simples bens negociáveis no mercado não seria esquecer sua particularidade - a função de financiamento, que faz de seus proprietários não apenas consumidores de bens financeiros, mas também, parceiros da companhia emissora. Uma das lições da crise não é o fato de que se deve procurar o inverso? Em vez de suprimir a noção, seria preciso empenhar-se na sua renovação, trabalhando a especificidade de tais valores mobiliários e buscando uma maneira de traduzir, em uma definição ou em um regime específico, referida particularidade",

${ }^{46}$ ALAIN, Viandier, op. cit., p. 123. Tradução livre: “A oferta pública, sendo um instrumento de tomada de controle, visa, principalmente, os valores mobiliários com direito a voto, quais sejam as ações - ordinárias ou preferenciais. Ocorre que outros valores mobiliários podem ter sido emitidos pela companhia visada, os quais dão acesso ao capital (C. com., art. L. 228-91). São eles as debêntures conversíveis, os bônus autônomos de subscrição e todas as variedades desenvolvidas pelos profissionais".
} 
Quanto à expressão "companhia aberta", trata-se de um requisito da oferta pública de aquisição. Caso contrário, ou seja, de companhia fechada, afirma Alain Viandier que "on ne saurait parler d'offre publique d'acquisition au sens de la réglementation boursière" ${ }^{47}$. Em outras palavras, no caso de oferta pública de aquisição relacionada a companhia fechada $^{48}$, não se aplica o RG da $\mathrm{AMF}$, mas existe tal operação no direito francês ${ }^{49}$.

\subsection{Histórico da legislação.}

Com relação à origem da oferta pública de aquisição, na França, segundo Pierre Bézard, ela se deu em 1959 e 1960, embora tenham tido importância limitada ${ }^{50}$. Outros autores entendem que mencionada origem encontra-se na oferta pública de aquisição lançada sobre Franco Wyoming Oil Company por três sociedades americanas, em $1964^{51}$.

Apesar da controvérsia existente, a oferta de 1964 permitiu que fossem reveladas as lacunas existentes na legislação francesa, com relação à matéria ora analisada, conduzindo à elaboração de uma primeira série de disposições, conforme a seguir indicado $^{52}$.

A primeira regulamentação das ofertas públicas de aquisição resultou de uma troca de cartas ocorrida em $1966^{53}$, por meio da qual a Companhia dos Corretores fez com que o Ministro da Economia e das Finanças aprovasse as principais regras por ela estabelecidas a respeito de uma oferta pública de aquisição. Essas regras tinham como objetivo controlar tais operações e evitar a ocorrência de abusos, inexistindo, contudo, o objetivo de entravá-las.

\footnotetext{
${ }^{47}$ VIANDIER, Alain, op. cit., p. 7.

${ }^{48}$ RONZANO, A. Offre publique d'achat d'actions non cotées. Revue de droit bancaire et de la bourse, Paris, 1993, p. 31.

${ }^{49}$ VIANDIER, Alain, op. cit., p. 7.

${ }^{50}$ Nesse sentido afirma o autor em questão: "Quelques offres publiques d'importances limitées avaient été lancées en France en 1959 et 1960 (ainsi l’O.P.A. Arthur Martin sur Saprine et Compagnie Française des Pétroles sur Omnium des Pétroles)" (BÉZARD, Pierre. Les offres publiques d'achat. Paris: Masson, 1982, p. 25). Tradução livre: "Algumas ofertas públicas pouco importantes foram lançadas na França em 1959 e 1960 (assim a O.P.A. lançada por Arthur Martin sobre Saprine e a lançada por Compagnie Française des Pétroles sobre Omnium des Pétroles)".

51 TROCHU, M. Les offres publiques d'achat. Revue trimestrielle de droit commercial et de droit économique, Paris, 1967. 695 spéc., p. 697.

${ }^{52}$ BÉZARD, Pierre, op. cit., p. 25.

${ }^{53}$ Segundo Pierre Bézard, trata-se das cartas, datadas de 4 de abril, 6 de julho e 29 de novembro de 1966 (Idem, ibidem).
} 
As regras de 1966 demonstraram-se insuficientes ${ }^{54}$, tendo sido necessária uma nova reforma, em 1970. Inicialmente, foi feita a incorporação ao RG da Companhia dos Corretores dos dispositivos referentes às ofertas públicas de aquisição. Em seguida, a Commission des opérations de bourse (COB), sob a forma de uma decisão geral de 13 de janeiro de 1970, aprovada pelo Ministro da Economia e das Finanças, em 21 de janeiro de 1970, elaborou um "código de boa conduta", o qual previa o respeito pelas sociedades envolvidas nas ofertas públicas de aquisição de diversas obrigações referentes à informação dos acionistas ${ }^{55}$.

Tais textos foram completados ao longo dos anos seguintes. Num primeiro momento, um Arrêté, de 17 de fevereiro de 1972, organizou, ao lado do procedimento normal correspondente à aquisição do controle, um procedimento de oferta simplificado, permitindo a uma pessoa que detenha o controle de uma sociedade adquirir as ações de titularidade dos acionistas remanescentes. Em seguida, o procedimento das ofertas públicas de aquisição, reservado até então à aquisição do controle ou reforço de um controle já existente, foi estendido às ofertas simplesmente minoritárias (v.g. algumas hipóteses de oferta pública de retirada, que serão analisadas no item 2.5.1 ${ }^{56}$, através do Arrêté, de 6 de março de $1973^{57}$. Ademais a COB completou, em 26 de julho de 1974, seu "código de boa conduta", a fim de evitar que abusos de bens sociais fossem praticados por administradores envolvidos na oferta pública de aquisição e para assegurar a transparência do mercado durante esse período ${ }^{58}$.

\footnotetext{
${ }^{54}$ Michel Refait enfatiza a "informalidade" da regulamentação de 1966 da seguinte maneira: "La réglementation de 1966 prit la forme d'un échange de lettres entre le Syndic des Agents de Change et le Ministre de l'Economie et des Finances. Cette procédure très informelle, qui ne fit l'objet d'aucune publication, instaurait la vérification de l'objet de l'offre et la justification du prix, ainsi que la publicité des modalités de l'offre et ses résultats" - REFAIT, Michel. Rôle économique des offres publiques d'achat e d'échange. Paris, 1990. Tese (Doutorado em direito). Université Paris II, p. 13. Tradução livre: "A regulamentação de 1966 foi realizada sob a forma de troca de cartas entre a Companhia dos Corretores e o Ministro da Economia e das Finanças. A regulamentação em questão, bastante informal, não foi sequer publicada e estabelecia a verificação do objeto da oferta e a justificação do preço, bem como a publicidade das modalidades da oferta e de seus resultados".

${ }^{55}$ BÉZARD, Pierre, op. cit., p. 27.

${ }^{56}$ Idem, ibidem.

${ }^{57}$ Sobre os citados Arrêtés, ensina Michel Refait: "Un arrêté du 17 Février 1972 instituait une procédure simplifiée d'acquisition des actions des minoritaires, en cas de contrôle d'une société. Un arrêté du 6 Mars 1973 étendait la procédure des offres publiques aux prises de participation minoritaires" (REFAIT, Michel, op. cit., p. 13). Tradução livre: "A decisão de 17 de fevereiro de 1972 instituía um procedimento simplificado de aquisição das ações dos minoritários, no caso de haver controle de uma sociedade. A decisão datada de 6 de março de 1973 ampliava o procedimentos das ofertas públicas às tomadas de participação minoritárias".

${ }^{58}$ BÉZARD, Pierre, op. cit., p. 27.
} 
A melhora na disciplina das ofertas públicas de aquisição permitiu o desenvolvimento de tais operações, na França, apesar de existir certa "morosidade na bolsa”. Nesse sentido, afirma Pierre Bézard:

\begin{abstract}
"L'amélioration de la réglementation a indiscutablement permis l'acclimatation en France des offres publiques et leur développement malgré une conjoncture boursière morose. Les chiffres sont assez significatifs à cet égard. Alors qu'en 1966 avaient eu lieu 2 offres publiques (2 O.P.A.), en 1967 il y en eut 7 (7 O.P.A.), en 1968: 11 (11 O.P.A.); les chiffres allaient augmenter de façon importante à partir de 1972: 38 (31 O.P.A., 7 O.P.E.). L'année 1973 vit 38 offres publiques (20 O.P.A., 18 O.P.E.), 1974: 23 (16 O.P.A., 7 O.P.E.), 1975: 20 (11 O.P.A., 9 O.P.E.), 1976: 27 (19 O.P.A., 8 O.P.E.), 1977: 36 (26 O.P.A., 10 O.P.E. ${ }^{, 59}$.
\end{abstract}

Esse panorama favorável às ofertas públicas de aquisição não se aplicava, no entanto, às ofertas públicas hostis, mostrando-se a regulamentação em vigor insuficiente em relação às citadas operações ${ }^{60}$.

Assim sendo, foi realizada a reforma de 1978 cujo objetivo, como aponta Alain Viandier, era triplo: simplificar e diversificar os procedimentos referentes à oferta pública de aquisição (distinção entre o procedimento normal e simplificado ${ }^{61}$ ), precisar as regras

\footnotetext{
${ }^{59}$ BÉZARD, Pierre, op. cit., p. 27. Tradução livre: "A melhora na regulamentação permitiu indiscutivelmente a adaptação das ofertas públicas na França e seu desenvolvimento, conquanto as condições de mercado não fossem favoráveis, em razão da morosidade. Os números são bastante significativos a esse respeito. Enquanto que em 1966 houve 2 ofertas públicas (2 O.P.A.), em 1967 foram realizadas 7 (7 O.P.A.), em 1968: 11 (11 O.P.A.); os números aumentaram de modo importante a partir de 1972: 38 (31 O.P.A., 7 O.P.E.). No ano de 1973, ocorreram 38 ofertas públicas (20 O.P.A., 18 O.P.E.), 1974: 23 (16 O.P.A., 7 O.P.E.), 1975: 20 (11 O.P.A., 9 O.P.E.), 1976: 27 (19 O.P.A., 8 O.P.E.), 1977: 36 (26 O.P.A., 10 O.P.E.) ".

${ }^{60}$ Pierre Bézard lembra que "ces offres contestées, soit au moyen d'une contre-offre, soit au cours d'une bataille boursière, avaient d'ailleurs été peu nombreuses ( 2 en 1967, 2 en 1969, 1 en 1972, 4 en 1973, 1 en 1974, 2 en 1975, 1 en 1976), ce qui établissait bien d'ailleurs les difficultés qu'elles avaient à se développer. Elles avaient d'ailleurs toutes échoué" (Idem, p. 27-28). Tradução livre: "tais ofertas contestadas, seja por meio de uma contraoferta seja através de uma batalha no mercado, tinham sido pouco numerosas ( $2 \mathrm{em} \mathrm{1967,}$ 2 em 1969, 1 em 1972, 4 em 1973, 1 em 1974, 2 em 1975, 1 em 1976)".

${ }^{61}$ A respeito da necessidade de se diversificar os procedimentos relativos às ofertas públicas, afirma Pierre Bézard o seguinte: "Les pouvoirs publics boursiers ont constaté, au regard de leur pratique et des dispositions des pays étrangers, que la réglementation française avait, à tort, établi un cadre unique devant s'appliquer à des réalités fort différentes. Ils ont relevé que l'on pouvait discerner en fait plusieurs types d'offres. Il s'agit, d'une part, d'offres publiques ayant pour but de permettre de prendre le contrôle d'une société. D'autre part, d'offres ayant pour objet d'acquérir une fraction relativement faible du capital d'une société. Enfin, d'offres fournissant le moyen à une personne, contrôlant déjà très largement une société, de la fermer la plus complètement possible pour obtenir, par exemple, qu'elle ne soit plus considérée comme faisant publiquement appel à l'épargne, ou pour offrir un droit de retrait aux actionnaires minoritaires. Ils ont établi en conséquence une procédure dite normale, s'appliquant aux offres de prise de contrôle (...) et une procédure qualifiée de simplifiée concernant les offres de fermeture, prévoyant un assouplissement sensible
} 
aplicáveis às batailles boursières e aumentar a qualidade da informação concedida ao público ${ }^{62}$.

A reforma de 1978 resultou, por exemplo, nos seguintes textos: Arrêté, de 7 de agosto de 1978, que instituiu o comitê de vigilância das ofertas públicas de aquisição; modificação do Capítulo II do título VI do RG da Companhia dos Corretores homologada por Arrêté do Ministro da Economia e das Finanças, de 7 de agosto de 1978; decisão geral da COB referente às ofertas públicas de compra e de permuta, de 25 de julho de 1978; instruções da COB, de 5 de setembro de 1978 , relativas às notas de informação ${ }^{63}$.

Após, foram realizadas diversas modificações, tais como, a de 1986, com a supressão, ao menos formal, do direito de oposição do Ministro da Economia e das Finanças ${ }^{64}$; a de 1989, para, por exemplo, estabelecer em quais condições se tornou obrigatória a realização de uma oferta pública de aquisição ${ }^{65}$ e para criar o Conseil des bourses de valeurs (CBV); a de 1993, para introduzir o retrait obligatoire (retirada

des règles" (BÉZARD, Pierre, op. cit., p. 30-31). Tradução livre: "Os poderes públicos constataram, com base na prática e nas disposições do direito estrangeiro, que a legislação francesa estabeleceu equivocadamente um conjunto único a ser aplicado a realidades distintas. Eles observaram que, na verdade, era possível distinguir diferentes tipos de ofertas. Havia, de um lado, as ofertas públicas com o objetivo de permitir a tomada do controle de uma sociedade. De outro lado, as ofertas com o objetivo de adquirir uma fração relativamente baixa do capital social de uma sociedade. Enfim, outras ofertas que ofereciam ao controlador a possibilidade de fechamento de capital ou que permitiam um direito de retirada aos acionistas minoritários. Consequentemente, foi instaurado um procedimento normal aplicável às ofertas de tomada de controle (...) e um procedimento chamado de simplificado referente às ofertas de fechamento, prevendo uma importante mitigação das regras".

${ }^{62}$ VIANDIER, Alain, op. cit., p. 15.

${ }^{63}$ BÉZARD, Pierre, op. cit., p. 28.

${ }^{64}$ Até 1986, o Ministro da Economia e das Finanças possuía o direito de se opor à realização da oferta pública de aquisição. A esse respeito, ensina Michel Refait: "En 1986, les textes suppriment le pouvoir discrétionnaire du Ministre des Finances de refuser un projet d'offre publique, laissant établir le prix et le volume de la transaction par le marché, plutôt que la chambre syndicale (...)" (REFAIT, Michel, op. cit., p. 14). Tradução livre: "Em 1986, os textos suprimiram o poder discricionário do Ministro das Finanças de recusar um projeto de oferta pública, cabendo ao mercado e não à Câmara Sindical o estabelecimento do preço e do volume de transação (...)".

${ }^{65}$ Afirma Philippe Merle que a reforma de 1989, através da Lei no 89-531, de 2 de agosto de 1989, introduziu uma modificação essencial "en rendant obligatoire le déclenchement d'une offre publique dès lors qu'un certain seuil est atteint. En effet, lorsqu'une personne physique ou morale, agissant seule ou de concert, vient à détenir plus du tiers des titres de capital ou plus du tiers des droits de vote d'une société française dont les titres sont admis aux négociations sur un marché réglementé, elle est tenue, à son initiative, d'en informer immédiatement l'AMF. Et elle doit déposer un projet d'offre publique libellé à des conditions telles, notamment quant au prix offert, qu'il puisse être déclaré recevable par l'Autorité des marchés financiers" (MERLE, Philippe. Droit commercial: sociétés commerciales. 14. ed. Paris: Dalloz, 2010, p. 825). Tradução livre: "ao tornar obrigatória a realização de uma oferta pública, desde que determinado limite fosse atingido. Quando uma pessoa física ou jurídica, agindo sozinha ou em conjunto, passa a deter mais de um terço do capital ou mais de um terço dos direito de voto de uma companhia francesa de capital aberto, deve informar imediatamente a AMF. Ademais, é preciso que seja protocolado um projeto de oferta pública, que deve preencher determinadas condições, notadamente com relação ao preço da oferta, para que seja registrado perante a Autoridade dos mercados financeiros". 
obrigatória $^{66}$ ); a de 2003, para criar a AMF, decorrente da fusão da COB, do Conseil des marchés financiers (CMF) e do Conseil de discipline de la gestion financière (CDGF), sucessor do CBV; a de 2006, quando da transposição da Diretiva n ${ }^{\circ}$ 2004/25/CE, para, por exemplo, disciplinar os mecanismos de defesa adotados durante a oferta pública de aquisição, bem como aumentar a qualidade das informações concedidas aos acionistas e aos assalariados ${ }^{67}$.

\subsection{Autoridade dos Mercados Financeiros.}

No final da década de 1960, a França decidiu que confiaria a regulação dos mercados financeiros a organismos administrativos e profissionais independentes. Essa decisão se enquadrava em um movimento mais amplo de abandono das formas clássicas de intervenção do Estado em certos setores da atividade ${ }^{68}$.

Nesse contexto, foi instituída, segundo o modelo da Securities and Exchange Commission, a COB, através da Ordonnance no 67-833, de 28 de setembro de 1967. Qualificada como autoridade administrativa independente, sua missão, conforme lembra Thierry Bonneau, consistia em "veiller 'à la protection de l'épargne investie dans les instruments financiers et tous autres placements donnant lieu à appel public à l'épargne, à

\footnotetext{
${ }^{66}$ Trata-se, em princípio, de uma modalidade de oferta pública de aquisição e será resumidamente analisada no item 2.5.2 do presente Capítulo.

${ }^{67}$ VIANDIER, Alain, op. cit., p. 15.

${ }^{68}$ Com relação aos motivos da decisão em questão, afirma Thierry Bonneau: "Elle s'expliquait par plusieurs raisons: le désir d'endiguer une certaine 'crise de légitimité' des activités financières et 'd'offrir à l'opinion une garantie renforcée d'impartialité des interventions de l'État'; la nécessité de faire face à la technicité de la matière et à la rapidité de ses mutations, grâce à l'aide de professionnels, spécialistes des questions financières; la volonté de se donner des moyens d'intervention plus efficaces que les moyens classiques dans un domaine où les enjeux financiers et les risques du marché imposent une prise de décision rapide; enfin et surtout, la recherche d'une meilleure crédibilité internationale. La régulation est apparue comme une réponse adaptée à ces différentes attentes dans la mesure où ce nouveau mode d'intervention suppose la mise en place 'd'autorités de régulation' chargées, au-delà de la définition des règles du jeu, d'une fonction d'arbitrage exprimée par la voie de décisions individuelles, et d'une mission de supervision et de contrôle dont la forme la plus aboutie est le pouvoir de sanction" (BONNEAU, Thierry; DRUMMOND, France, op. cit., p. 346347). Tradução livre: "Ela se explicava por diversas razões: o desejo de reprimir certa 'crise de legitimidade' das atividades financeiras e de 'oferecer à opinião pública' uma garantia reforçada de imparcialidade das intervenções do Estado; a necessidade de atender às exigências da matéria e à rapidez de suas mudanças; a vontade de instituir meios de intervenção mais eficazes em comparação com os meios clássicos, em um ambiente em que as questões financeiras e os riscos do mercado impõem uma tomada rápida de decisão; enfim e, sobretudo, a procura de uma melhor credibilidade internacional. A regulação se revelava como uma resposta adaptada às mencionadas expectativas, na medida em que esse novo modo de intervenção supõe a criação de 'autoridades de regulação' incumbidas, além das disposições das regras do jogo, de uma função de arbitragem e de uma missão de supervisão e de controle cuja forma mais característica é o poder de sanção".
} 
l'information des investisseurs et au bon fonctionnement des marchés financiers" ",69 A fim de realizar tais funções, a $\mathrm{COB}$ possuía certo número de poderes, quais sejam poder de regulamentar, poder de controle e de sanção ${ }^{70}$, aos quais, como lembra referido autor, foi acrescentado o poder de mediação ${ }^{71}$.

Até 1996, a COB coexistiu com dois outros organismos profissionais - a saber: o CBV e o Conseil des marchés à terme (CMT). Com a transposição da Diretiva $\mathrm{n}^{\circ}$ 93/22/CEE do Conselho, de 10 de maio de 1993, pela Lei n ${ }^{\circ}$ 96-597, de 2 de julho de $1996^{72}$, houve a modernização da organização institucional dos mercados, resultando na criação de uma nova autoridade: o CMF, o qual substituiu o CBV e o CMT.

O CMF consistia em uma autoridade profissional dotada de personalidade jurídica e seu campo de intervenção, no que se refere às ofertas públicas de aquisição, em princípio, era, principalmente, o do procedimento da operação. Era, pois, o CMF que decidia sobre o recebimento de um projeto de oferta pública de aquisição ${ }^{73}$.

Na prática, contudo, a divisão de tarefas entre esses dois órgãos (COB e CMF) era menos evidente, podendo ocorrer que ambos tivessem visões diferentes sobre determinada oferta pública de aquisição. Outrossim, a dualidade de interlocutores, segundo Alain Viandier, configurava "uma complicação inútil",74. Fazia-se, pois, necessária a fusão dos referidos órgãos, o que ocorreu com a Lei $\mathrm{n}^{\mathrm{o}} 2003-706$, de $1^{\circ}$ de agosto de 2003, promovendo a substituição da $\mathrm{COB}$, do $\mathrm{CMF}$ e do Conseil de discipline de la gestion financière pela AMF.

A AMF tem sua competência determinada pelo artigo L. 621-1 do C. mon. fin., cabendo-lhe, por exemplo: cuidar da proteção da poupança investida nos instrumentos financeiros e nos ativos mencionados no artigo L. 421-1, II, do C. mon. fin. quando relacionados à oferta pública ou à distribuição. Ela cuida, igualmente, da informação dos

\footnotetext{
${ }^{69}$ BONNEAU, Thierry; DRUMMOND, France, op. cit., p. 348.

${ }^{70}$ Michel Refait aponta que o objetivo da COB era menos repressivo do que aquele da Securities and Exchange Commission, por exemplo (REFAIT, Michel, op. cit., p. 55).

${ }^{71}$ BONNEAU, Thierry; DRUMMOND, France, op. cit., p. 348.

${ }^{72}$ Trata-se da Lei de modernisation des activités financières, chamada de loi MAF.

${ }^{73}$ VIANDIER, Alain, op. cit., p. 29.

${ }^{74}$ Idem, ibidem.
} 
investidores e do bom funcionamento dos mercados de instrumentos financeiros e dos ativos mencionados no artigo L. 421-1, II, do C. mon. fin.

Os conceitos de instrumento financeiro e dos citados ativos são, portanto, balizadores da competência da AMF. Da mesma maneira, o conceito de valor mobiliário define, de certa maneira, a competência da Comissão de Valores Mobiliários (CVM) no direito brasileiro ${ }^{75}$.

A AMF constitui, em consonância com o artigo L. 621-1 do C. mon. fin., uma autoridade pública independente, sendo dotada de personalidade jurídica. Prevê o artigo L. 621-2, I e II, do C. mon. fin. que, salvo disposição contrária, as atribuições conferidas à AMF são exercidas por um colégio, composto por 16 membros e que, nas palavras de Thierry Bonneau, "est l'organe décisionnel de l'AMF",76.

Em resposta à crítica da Corte de Apelação (CA) de Paris, que apontou a singularidade do funcionamento e dos poderes da COB, ao confundir, no mesmo órgão de decisão, as funções de investigação, instrução e de constatação da culpabilidade ${ }^{77}$, a competência repressiva da AMF foi conferida à comissão de sanções, composta por 12 membros, conforme o artigo L. 621-2, IV, do C. mon. fin. ${ }^{78}$.

\subsection{Modalidades.}

Diversas são as modalidades de oferta pública de aquisição existentes na França e diferentes são os critérios utilizados pelos autores para classificá-las.

\footnotetext{
${ }^{75}$ Decorre disso, conforme Nelson Eizirik, que "as operações envolvendo esses tipos de títulos ou contratos serão reguladas e fiscalizadas por essa autarquia". É preciso notar que o âmbito de atuação em questão já foi ampliado diferentes vezes. É o caso, por exemplo, da ampliação realizada com a edição da Lei no 10.303/01 (EIZIRIK, Nelson; GAAL, Ariádna B.; PARENTE, Flávia; HENRIQUES, Marcus de Freitas. Mercado de capitais regime jurídico. 2. ed. São Paulo: Renovar, 2008, p. 247).

${ }^{76}$ BONNEAU, Thierry; DRUMMOND, France, op. cit., p. 350.

77 A CA de Paris, em sua decisão de 7 de maio de 1997, confirmada pela C. cass., em decisão de 5 de fevereiro de 1999, anulou a decisão da COB, impondo uma sanção ao presidente do conselho de administração de determinada sociedade. Os fundamentos da decisão em questão foram: (1) o princípio da presunção de inocência, consagrado pelo artigo $6^{\circ}$, §2 $2^{\circ}$, da Convenção Europeia dos Direitos do Homem e (2) o funcionamento institucional da $\mathrm{COB}$, no que se refere ao andamento do procedimento de sanções administrativas, previsto pelo artigo 9-2 da Ordonnance $\mathrm{n}^{\circ}$ 67-833, de 28 de setembro de 1967, bem como a questão da compatibilidade da participação do rapporteur (relator) da decisão sobre a aplicação da sanção pelo colégio da $\mathrm{COB}$ com o artigo $6^{\circ}$ da mencionada Convenção e com o princípio fundamental relacionado aos direitos de defesa (CA Paris, 07.05.97: JCP 97, E, 676, n 14 nota de A. Viandier e J.-J. Caussain e C. cass. ass. plén., 05.02.99: JCP 99, G, p. 361).

${ }^{78}$ VIANDIER, Alain, op. cit., p. 29.
} 
A OPA será analisada no Capítulo 3. É importante, no entanto, que se tenha uma noção breve (sendo analisados apenas os aspectos gerais) sobre outras modalidades de ofertas públicas de aquisição, tais como a oferta pública de retirada (offre publique de retrait $)^{79}$ e a retirada obrigatória (retrait obligatoire), porquanto esta, por exemplo, pode ser realizada ao final de qualquer oferta pública de aquisição, até mesmo da OPA, excluindo-se o estudo do procedimento ${ }^{80}$ referente às referidas operações.

\subsubsection{Oferta pública de retirada.}

A oferta pública de retirada é concebida, no direito francês, como um mecanismo de proteção aos acionistas minoritários, já que conduz, em determinados casos previstos no $\mathrm{RG}$ da $\mathrm{AMF}$, à retirada do acionista da companhia.

Os casos de aplicação da oferta pública de retirada são limitativamente enumerados pelos artigos 236-1 a 236-7 do RG da AMF, em consonância com o previsto no artigo L. 433-4 do C. mon. fin. Referida oferta pública é prevista em três hipóteses, a seguir indicadas: detenção de, ao menos, 95\% dos direitos de voto da companhia; transformação de uma sociedade anônima em sociedade em comandita por ações e modificações jurídicas ou econômicas significativas.

No direito brasileiro, não há a modalidade de oferta pública de retirada tal como existente na França. Existe, no entanto, o direito de retirada ${ }^{81}$, ou seja, a faculdade de o

\footnotetext{
${ }^{79}$ Os procedimentos referentes às ofertas públicas de retirada, sob um ponto de vista amplo, não possuem como objetivo a aquisição do controle interno de uma companhia, já que, por definição, dependendo do caso, o ofertante já o possui quando a oferta é lançada. Geralmente, o que se almeja é "indenizar" os minoritários e realizar o "fechamento de capital", podendo, contudo, a operação apresentar outros objetivos (OHL, Daniel, op. cit., p. 320).

${ }^{80}$ Apesar de excluído o estudo do procedimento, é preciso notar que às ofertas públicas de aquisição, no direito francês, aplica-se o procedimento normal ou o simplificado. O primeiro é a regra, sendo que o segundo pode se aplicar aos casos previstos no artigo 233-1 do RG da AMF. A título de exemplo, aplica-se o procedimento simplificado à oferta pública de retirada. Em regra, à OPA aplica-se o procedimento normal.

${ }^{81}$ Além do direito de retirada, é preciso citar o artigo $10, \S 2^{\circ}$, da Instrução CVM n ${ }^{\circ} 361 / 02$, que dispõe o seguinte: "Ressalvada a hipótese de OPA por alienação de controle, do instrumento de qualquer OPA formulada pelo acionista controlador, pessoa a ele vinculada ou a própria companhia, que vise à aquisição de mais de 1/3 (um terço) das ações de uma mesma espécie ou classe em circulação, constará declaração do ofertante de que, caso venha a adquirir mais de $2 / 3$ (dois terços) das ações de uma mesma espécie e classe em circulação, ficará obrigado a adquirir as ações em circulação remanescentes, pelo prazo de 3 (três) meses, contados da data da realização do leilão, pelo preço final do leilão de OPA, atualizado até a data do efetivo pagamento, nos termos do instrumento de OPA e da legislação em vigor, com pagamento em no máximo 15
} 
acionista retirar-se da sociedade, nos casos previstos em lei, por meio da reposição patrimonial das ações respectivas ${ }^{82}$. Trata-se de mecanismo, em princípio, menos complexo, se comparado com a oferta pública de retirada, que precisa seguir todo o procedimento previsto no RG da AMF, devendo ser submetida a registro perante a AMF. Apesar disso, através de mecanismos diferentes, possibilita-se a saída do acionista, nos casos previstos pelas respectivas legislações.

\subsubsection{Detenção de determinado percentual dos direitos de voto.}

Os artigos a serem aqui considerados são os 236-1 a 236-4 do RG da AMF, nos quais a diferença fundamental entre as duas principais hipóteses de oferta pública de retirada está no fato de a primeira, prevista no artigo 236-1 do RG da AMF, resultar da demanda de um acionista minoritário, e a segunda, prevista no artigo 236-3 do RG da AMF, resultar da demanda de um acionista que detenha, ao menos, 95\% dos direitos de voto da companhia ${ }^{83}$.

Apesar dessa diferença, a finalidade é a mesma. Como resumido pela CA de Paris, em decisão proferida em 25 de fevereiro de 1994, mencionada finalidade consiste em “permettre à l'actionnaire minoritaire dont le titre a perdu sa liquidité sur un marché rendu étroit par le poids des majoritaires, de sortir de la société dans des conditions normales de cours et de délai" ${ }^{\prime 4}$. Com disso, será, primeiramente, estudada a oferta pública de retirada requerida por acionista minoritário e, após, aquela requerida por acionista majoritário.

Não há no direito brasileiro disposição legal que condicione o direito de retirada diretamente à detenção de determinado percentual dos direitos de voto, como no caso do direito francês. O que há é a previsão do direito de retirada no caso, por exemplo, da criação de ações preferenciais ou aumento de classe de ações preferenciais existentes, sem guardar proporção com as demais classes de ações preferenciais, salvo se existir previsão

(quinze) dias contados do último a ocorrer dos seguintes eventos: I - exercício da faculdade pelo acionista; ou II - pagamento aos demais acionistas que aceitarem a OPA, no caso de OPA com pagamento a prazo".

${ }^{82}$ CARVALHOSA, Modesto. Comentários à lei das sociedades anônimas. v. 2. 4. ed. São Paulo: Saraiva, 2008, p. 137.

${ }^{83}$ VIANDIER, Alain, op. cit., p. 428.

${ }^{84}$ CA Paris, 1 ch. A, sect. CBV, 25.02.95, Société Financière CIRCE, decisão confirmada pela C. cass. (C. cass., 06.05.96: JCP, E, p. 747). Tradução livre: "permitir que o acionista minoritário cujo título perdeu sua liquidez se retire da sociedade em condições normais de preço e de prazo". 
estatutária nesse sentido (art. 136, I, da $\operatorname{LSA}^{85}$ ). Ambos os dispositivos, contudo, servem como proteção aos acionistas minoritários.

\subsection{Oferta pública de retirada requerida por acionista minoritário.}

É preciso que sejam levadas em conta algumas condições para o lançamento da oferta pública em questão. A primeira condição se refere ao fato de que a oferta pública pode ser requerida pelo acionista minoritário quando o ou os acionistas majoritários detiverem, em conjunto, de acordo com o artigo L. $233-10^{86}$ do C. com., ao menos $95 \%$ dos direitos de voto.

Como ensina Alain Viandier, as circunstâncias que presidiram à detenção de, ao menos, 95\% dos direitos de voto da companhia são indiferentes. Assim, pouco importa que tal nível de detenção resulte de um ato voluntário do acionista, ou que ele seja a consequência da decisão de um terceiro ${ }^{87}$.

A segunda condição se refere ao acionista minoritário e possui como fundamento o artigo 236-1 do RG da AMF, que dispõe acerca da pessoa que pode requerer à AMF a apresentação de um projeto de oferta pública de retirada: "le détenteur de titres conférant des droits de vote n'appartenant pas au groupe majoritaire" ${ }^{\text {" } 88}$.

A última condição está relacionada à AMF e possui, também, como fundamento o artigo 236-1, al. 2, do RG da AMF. Dessa forma, a AMF, após realizar as verificações necessárias, se pronunciará a respeito do projeto apresentado com base nas condições que prevalecerem no mercado e nas informações trazidas pelo requerente ${ }^{89}$. Depreende-se da leitura do mencionado dispositivo que a simples reunião das condições formais não é

\footnotetext{
${ }^{85}$ Complementa o artigo 137, I, da LSA que, neste caso, somente terá direito de retirada o titular de ações de espécie ou classe prejudicadas.

${ }^{86}$ Segundo o artigo L. 233-10, I, do C. com. são consideradas como agindo em conjunto "les personnes qui ont conclu un accord en vue d'acquérir, de céder ou d'exercer des droits de vote, pour mettre en œuvre une politique commune vis-à-vis de la société ou pour obtenir le contrôle de cette société". Tradução livre: "as pessoas que celebraram um acordo visando à aquisição, à cessão ou ao exercício dos direitos de voto, a fim de implementarem uma política comum com relação à sociedade ou para obterem seu controle".

${ }^{87}$ VIANDIER, Alain, op. cit., p. 429.

${ }^{88}$ Tradução livre: "o detentor de valores mobiliários, que conferem direitos de voto, não pertencente ao grupo majoritário".

${ }^{89}$ VIANDIER, Alain, op. cit., p. 431.
} 
suficiente para que a demanda do acionista minoritário seja atendida. Faz-se, pois, necessário que a AMF se pronuncie a respeito ${ }^{90}$.

No que tange aos critérios sobre os quais se funda a $\mathrm{AMF}^{91}$ para aceitar ou recusar o requerimento apresentado pelo minoritário, vale ressaltar que se analisa a possibilidade de o acionista ceder seus valores mobiliários, considerando a liquidez do mercado ${ }^{92}$. Além disso, conforme sublinha Alain Viandier, considera-se, também, a situação particular do acionista que requer a oferta pública de retirada. Nas palavras do referido autor, tal procedimento não se destina a “ouvrir une 'session de rattrapage' au profit d'actionnaires ayant par exemple refusé d'apporter leurs titres à une offre publique (...)"93.

Em resumo, o titular de valores mobiliários remanescentes, se preenchidas as condições acima mencionadas, pode exigir que se proceda à aquisição dos seus valores mobiliários.

\footnotetext{
${ }^{90}$ Tal entendimento foi confirmado pela Corte de Cassação francesa (C. cass.), na decisão datada de 6 de maio de 1996 (C. cass., 06.05.96: JCP, E, p. 747).

${ }^{91}$ Conforme consta do Rapport annuel da AMF, de 2004, são levadas, ainda, em consideração as condições de aquisição dos valores mobiliários do requerente: "L'examen de ces demandes par l'AMF, en droite ligne avec la pratique du CMF confirmée par la jurisprudence de la cour d'appel de Paris saisie de recours, consiste à vérifier, d'une part, la liquidité du marché afin de déterminer s'il est possible au demandeur de céder des titres sur le marché dans des conditions normales de cours et de délai et d'autre part, les conditions d'acquisition des titres pour lesquels l'actionnaire demandeur requiert une possibilité de sortie" (Disponível em: 〈http://lesrapports.ladocumentationfrancaise.fr/BRP/054000353/0000.pdf $>$, p. 110. Acesso em: 03.05.11). Tradução livre: "A análise dessas demandas pela AMF, seguindo a prática do CMF confirmada pela jurisprudência do Corte de Apelação de Paris, consiste na verificação, de um lado, da liquidez do mercado, a fim de determinar se é possível ao demandante ceder seus valores mobiliários em condições normais de prazo e preço e, de outro lado, no exame das condições de aquisição dos valores mobiliários em questão".

${ }_{92}^{92}$ VIANDIER, Alain, op. cit., p. 431.

${ }^{93}$ Idem, p. 432. Tradução livre: "abrir uma sessão de recuperação para os acionistas que, por exemplo, se recusaram a participar de uma oferta pública anterior".
} 


\subsection{Oferta pública de retirada requerida por acionista majoritário ${ }^{94}$.}

O artigo 236-3 do RG da AMF permite o início espontâneo de uma oferta pública de retirada pelo acionista que detenha $95 \%$ dos direitos de voto de uma companhia. O dispositivo mencionado, conforme expressão utilizada por Alain Viandier, é "presque symétrique" com relação ao artigo 236-1 do RG da AMF, já que, enquanto um acionista minoritário pode, após ter sido deferida pela $\mathrm{AMF}$ a realização da oferta pública, obrigar o majoritário a comprar seus valores mobiliários, em decorrência de uma oferta pública de retirada, um acionista majoritário não pode fazer o mesmo com o minoritário, que é livre de ceder ou de conservar seus valores mobiliários, exceto se ocorrer a retirada obrigatória $^{95}$.

Para a ocorrência da oferta pública em epígrafe, são necessárias condições que dizem respeito ao acionista majoritário, bem como que dizem respeito à $\mathrm{AMF}$. Com relação às primeiras, o artigo 236-3 do RG da AMF se refere ao acionista majoritário através da seguinte fórmula: "le ou les actionnaires majoritaires qui détiennent de concert (...) au moins 95\% des droits de vote d'une société (...)". É importante sublinhar que as circunstâncias por meio das quais ocorreu a constituição da participação majoritária são indiferentes $^{96}$. Com relação às segundas, a única função da AMF é a de se pronunciar a respeito da conformidade da oferta, diferentemente da oferta constante do artigo 236-2 do RG da AMF, na qual esta, como acima estudado, aprecia a legitimidade da demanda do acionista minoritário ${ }^{97}$.

\footnotetext{
${ }^{94}$ Paul Didier explica o nascimento dos mecanismos de proteção dos majoritários, tal como o instituto analisado, da seguinte forma: "Les offres d'acquisition de la minorité sont nées comme des mécanismes de protection des minoritaires. Cependant, à la demande des majoritaires les pouvoirs publics ont développé des procédés empruntant leurs formes mais poursuivant l'objet inverse: l'offre ne se fait plus dans l'intérêt du minoritaire mais dans celui du majoritaire. L'intérêt que poursuit le majoritaire et qui est jugé suffisamment légitime par le législateur consiste à fermer la société c'est-à-dire faire quitter les minoritaires de façon à pouvoir retirer la société de la cote" (DIDIER, Paul; DIDIER, Philippe, op. cit., p. 1106). Tradução livre: "As ofertas públicas de aquisição da minoria nasceram como mecanismos de proteção dos minoritários. No entanto, atendendo ao pedido dos majoritários, os poderes públicos desenvolveram procedimentos, com base na forma das referidas ofertas, mas seguindo o objetivo inverso: a oferta não se faz mais com relação ao interesse do minoritário e sim ao do majoritário. O interesse almejado e julgado suficientemente legítimo pelo legislador consiste em promover a saída dos minoritários e realizar o fechamento de capital".

${ }_{95}$ VIANDIER, Alain, op. cit., p. 433.

${ }^{96}$ Idem, p. 434.

97 Idem, p. 434-435.
} 


\subsubsection{Transformação em comandita por ações.}

Antes da reforma do RG da COB de 1998, a transformação da sociedade anônima de capital aberto em comandita por ações configurava causa de oferta pública de retirada apenas se fosse possível identificar um ou vários acionistas titulares de 2/3 dos direitos de voto, o que não é comum para uma companhia aberta, aplicando-se à maioria das transformações as disposições relativas às modificações estatutárias significativas, que serão analisadas no item 2.5.1.3. Essa era a posição da $\mathrm{COB}$, conforme consta do seu Rapport annuel, de $1989^{98}$.

Com essa reforma, conforme aponta Alain Viandier, a oferta pública de retirada configura uma obrigação tanto para os controladores como para os futuros comanditados. Isso porque pode não existir acionista controlador, mas haverá necessariamente a figura do comanditado ${ }^{99}$.

Atualmente, a única condição para a realização da oferta pública analisada é a transformação de uma sociedade anônima de capital aberto em comandita por ações, não sendo, pois, necessária a sua realização quando, por exemplo, da cisão de uma sociedade anônima e a consequente criação de duas comanditas por ações ${ }^{100}$. Diante disso, os acionistas controladores ou os futuros comanditados não possuem escolha ${ }^{101}$, pois devem, conforme o artigo 236-5, al. 1, do RG da AMF, desde a deliberação tomada pela assembleia geral de acionistas relativa à transformação da sociedade, protocolar um projeto de oferta pública de retirada.

\subsubsection{Modificações jurídicas ou econômicas significativas.}

Consagrando antigas interpretações da COB, no sentido de conceder um direito de retirada, na hipótese de modificações jurídicas ou financeiras da sociedade, o artigo 236-

\footnotetext{
98 VIANDIER, Alain, op. cit., p. 434.

${ }^{99}$ Idem, p. 436.

${ }^{100}$ BONNEAU, Thierry; FAUGÉROLAS, Laurent. Les offres publiques. Paris: EFE, 2005, p. 69.

${ }^{101}$ Diz-se, pois, que a realização da oferta pública em questão ocorre "automaticamente", já que mencionada oferta é obrigatória desde a deliberação tomada pela assembleia geral dos acionistas relativa à transformação da sociedade (Idem, p. 69).
} 
$6^{102}$ do RG da AMF prevê duas séries de situações que justificam o recurso à oferta pública de retirada, quais sejam as modificações estatutárias significativas e as modificações econômicas e financeiras.

O dispositivo em questão está articulado, como observa Thierry Bonneau, "autour du principe simple selon lequel le ou les actionnaires contrôleurs de la société ont l'obligation d'avertir le CMF lorsqu'ils se proposent de modifier les statuts ou de décider d'une opération non négligeable pour l'ensemble des actionnaires"103. Assim, a oferta pública de retirada pressupõe que o controlador tenha a intenção de submeter à aprovação da assembleia geral de acionistas uma ou diversas modificações estatutárias significativas e/ou modificações econômicas e financeiras.

No que tange às modificações significativas das disposições estatutárias ${ }^{104}$, não há no artigo 236-6 do RG da AMF uma definição do que sejam tais modificações, existindo, contudo, alguns exemplos, tal como a cessão ou a transmissão de valores mobiliários ${ }^{105}$. A ocorrência pura e simples de uma delas não significa, no entanto, que se trata de uma modificação significativa das disposições estatutárias, sendo necessário analisar, caso a caso, o impacto da situação com relação, por exemplo, à situação dos acionistas minoritários ${ }^{106}$.

Quanto às modificações econômicas e financeiras, elas foram listadas pelo artigo 236-6, $2^{\circ}$, do RG da AMF. Como exemplo, podem ser citadas a reorientação da atividade social e a fusão da sociedade pelo controlador.

\footnotetext{
${ }^{102}$ Vale notar que, por muito tempo, o artigo 236-6 do RG da AMF gerou sérios problemas jurídicos, pois as hipóteses nele previstas não constavam da delegação feita à AMF pelos artigos L. 433-3 e L. 433-4 do C. mon. fin. Isso foi resolvido pela Lei $\mathrm{n}^{\circ}$ 2008-776, de 04.08.08, que modificou o artigo L. 433-4 do C. mon. fin.

${ }^{103}$ BONNEAU, Thierry; FAUGÉROLAS, Laurent, op. cit., p. 70. Tradução livre: “em torno do princípio simples segundo o qual o ou os acionistas da sociedade possuem a obrigação de avisar o CMF quando eles forem modificar o estatuto social ou quando decidirem pela realização de uma operação significativa para todos os acionistas".

${ }^{104}$ A título de exemplo, podem ser citadas as seguintes ofertas públicas de retirada decorrentes de tais modificações significativas das disposições estatutárias: Frandev (SBF, Avis n ${ }^{\circ}$ 90-3464, 24.10.90); Matra Hachette (SBF, Avis $\mathrm{n}^{\circ}$ 96-1537, 15.05.96); Aérospatiale Matra (CMF, décision $\mathrm{n}^{\circ}$ 200C0181, 03.02.00) (VIANDIER, Alain, op. cit., p. 441).

${ }^{105}$ Trata-se de lista exemplificativa, em razão do uso do advérbio notamment (art. 236-6 do RG da AMF).

${ }^{106}$ Diz Thierry Bonneau que a realização da modificação estatutária é insuficiente para gerar aos acionistas minoritários um direito de retirada (BONNEAU, Thierry; FAUGÉROLAS, Laurent, op. cit., p. 71).
} 
No artigo 236-6 do RG, al. 2, da AMF, é determinado que a AMF analisa as consequências da operação com base nos direitos e nos interesses dos acionistas e dos detentores de direitos de voto e decide sobre a necessidade de se realizar ou não uma oferta pública de retirada. Na prática, observa Alain Viandier que a AMF aprecia a necessidade de uma oferta pública de retirada em função de sua incidência sobre: a atividade da companhia; a organização da companhia; a liquidez das ações de emissão da companhia; a capacidade de a companhia distribuir dividendos, após, por exemplo, uma operação de fusão; o futuro da companhia ${ }^{107}$.

A pessoa física ou jurídica, que controla uma sociedade, possui a obrigação de informar a ocorrência das citadas modificações estatutárias significativas, bem como das modificações econômicas e financeiras, para que a AMF decida acerca da necessidade de realização de uma oferta pública de retirada, sendo a identificação do controlador feita, em consonância com as regras do artigo L. 233-3 do C. com. ${ }^{108}$

Diferentemente do artigo 236-5 do $\mathrm{RG}$ da $\mathrm{AMF}$, que determina que seja automaticamente apresentado um projeto de oferta pública de retirada decorrente da transformação da sociedade anônima em comandita por ações, o artigo 236-6 do RG da AMF impõe apenas uma obrigação de informar a AMF.

No direito brasileiro, o direito de retirada é taxativamente previsto no artigo 137 da LSA e as condições de sua aplicação também se encontram determinadas, contrariamente ao direito francês.

\subsubsection{Retirada obrigatória.}

\subsubsection{Origem e evolução.}

A introdução no direito francês de um procedimento diretamente inspirado no squeeze out norte-americano ${ }^{109}$ se justificou pela necessidade de se obter um procedimento

\footnotetext{
${ }^{107}$ VIANDIER, Alain, op. cit., p. 445.

108 Ver item 3.2.

${ }^{109}$ BONNEAU, Thierry; FAUGÉROLAS, Laurent, op. cit., p. 74.
} 
menos burocrático para o "fechamento de capital" 110111 . A retirada obrigatória foi criada pela Lei $\mathrm{n}^{\circ}$ 93-1444, de 31 de dezembro de 1993, e, atualmente, é disciplinada pelo artigo L. 433-4 do C. mon. fin. e pelos artigos 237-1 e seguintes do RG da AMF.

A retirada obrigatória, até a Lei n 2006-387, de 31 de março de 2006, era tida como o "remédio" das ofertas públicas de retirada inacabadas, ou seja, somente se realizava após a oferta pública de retirada, não se aplicando às demais modalidades de ofertas públicas, tal como a OPA, e gerando a seguinte situação, segundo Alain Viandier:

\begin{abstract}
"Même si le seuil de 95\% était atteint à la suite d'une offre publique ordinaire ou d'une garantie de cours, l'actionnaire concerné devait néanmoins déposer une offre publique de retrait pour pouvoir provoquer le retrait obligatoire. Autre motif de complication, l'offre de retrait devait précéder immédiatement le retrait obligatoire" ${ }^{, 12}$.
\end{abstract}

A Lei ${ }^{\circ}$ 2006-387, de 31 de março de 2006, modificou o artigo L. 433-4, III, do C. mon. fin., tendo sido simplificadas as condições de realização da retirada obrigatória, haja vista que passou a poder ser realizada após qualquer oferta pública de aquisição, desde que os valores mobiliários ${ }^{113}$ não submetidos à OPA pelos acionistas minoritários não representem mais do que $5 \%$ do capital ou dos direitos de voto. Trata-se de uma faculdade reconhecida ao ofertante. Caso este opte pela realização da retirada obrigatória, os titulares dos valores mobiliários remanescentes lhe transferirão os respectivos títulos e receberão, em contrapartida, determinado preço ${ }^{114}$. Atualmente, é a "l'offre publique la plus répandue

\footnotetext{
${ }^{110}$ No direito francês, não existe, como no direito brasileiro, uma oferta pública de aquisição de ações para cancelamento de registro (art. $4, \S 4$, da LSA), ou seja, um procedimento único que visa ao "fechamento de capital". Além da retirada obrigatória, outros procedimentos voltam-se, de certa forma, para a consecução do mencionado objetivo. É o caso da oferta pública de retirada de iniciativa do acionista majoritário (DIDIER, Paul; DIDIER, Philippe, op. cit., p. 1107).

${ }^{111}$ Além desse motivo, Laurent Faugérolas lembra que a oferta pública de retirada protegia, de certa maneira, os minoritários (FAUGÉROLAS, Laurent. Les offres publiques de retrait et le retrait obligatoire. Bulletin Joly Bourse, Paris, 1999, p. 52).

112 VIANDIER, Alain, op. cit., p. 452. Tradução livre: "Mesmo se o limite de 95\% fosse alcançado após uma oferta pública ou uma garantie de cours, o acionista deveria protocolar um projeto de oferta pública de retirada, a fim de poder provocar a retirada obrigatória. Outro motivo de complicação se referia ao fato de que a oferta de retirada deveria preceder imediatamente a retirada obrigatória”.

${ }^{113}$ Segundo Thierry Bonneau, "le retrait obligatoire est l'accessoire d'une offre publique de retrait dont il vient parfaire les effets à l'égard de l'actionnaire ou du groupe majoritaire" (BONNEAU, Thierry; FAUGÉROLAS, Laurent, op. cit., p. 75). Tradução livre: “a retirada obrigatória é um procedimento acessório à oferta pública de retirada cujos efeitos relativos ao acionista ou grupo de acionista ela perfaz"

${ }^{114}$ Apesar de o C. mon. fin. (art. L. 433-4, II, III), bem como o RG da AMF (arts. 237-1, al. 1, 237-7, 237-9, 237-10, al. 2, 237-11, 237-14, 237-18, 237-19), falarem em “ indenização” devida aos minoritários, trata-se, na realidade, de preço, já que não existe reparação de um dano, mas sim avaliação dos valores mobiliários cuja transferência foi ordenada. Nesse sentido, por exemplo, Alain Viandier (VIANDIER, Alain, op. cit., p.
} 
et (qui) a donné lieu à plusieurs centaines d'application au cours des dix dernières années"115.

\subsubsection{Procedimento.}

O RG da AMF continua a diferenciar, com relação ao procedimento, a retirada obrigatória após uma oferta pública de retirada (arts. 237-1 e seguintes do RG da AMF) e a retirada obrigatória após qualquer oferta pública de aquisição (arts. 237-14 e seguintes do $\mathrm{RG}$ da $\mathrm{AMF})^{116}$, procedimento esse que não será estudado, conforme acima indicado.

\subsubsection{Controvérsias.}

Existem, no direito francês, diversas discussões doutrinárias, a respeito da retirada obrigatória. A primeira delas se refere ao fato de que a retirada obrigatória é tratada, pela maioria dos autores, como uma modalidade de oferta pública e está inserida no Título III Capítulo VII - do RG da AMF, que disciplina as ofertas públicas de aquisição.

Ocorre que a retirada obrigatória, como indicado pelo seu próprio nome, não resulta de um acordo de vontades e não comporta oferta feita aos acionistas, tampouco aceitação de sua parte. Trata-se, na realidade, de um mecanismo de exclusão dos minoritários cuja aplicação pelo majoritário submete-se a uma condição objetiva relacionada à detenção de certa quantia de valores mobiliários representativos de determinada porcentagem do capital ou dos direitos de voto. Para alguns, é uma operação sui generis $^{117}$.

474) e Laurent Faugérolas (FAUGÉROLAS, Laurent. Les offres publiques de retrait et le retrait obligatoire. Bulletin Joly Bourse, Paris, 1999, p. 58).

${ }^{115}$ SCHMIDT, Dominique. Actualités du droit des offres publiques et de la sortie des minoritaires. Recueil Dalloz, Paris, 2005, p. 633.

${ }_{117}^{116}$ VIANDIER, Alain, op. cit., p. 452.

${ }^{117}$ Olivier Douvreleur afirma, nesse sentido, que "dépourvu de toute autonomie, le retrait obligatoire fait nécessairement suite à une offre préalable dont il constitue un complément éventuel. Il n'en a pas moins été conçu par le législateur comme une opération sui generis, ne présentant pas les caractères permettant de l'assimiler juridiquement à une offre publique: il résulte non d'une acceptation forcée d'une offre, mais d'un transfert obligatoire de titres donnant lieu, au profit de leurs propriétaires, au versement non d'un prix offert, mais d'une indemnisation" (DOUVRELEUR, Olivier. Un nouveau cas de retrait obligatoire: le retrait obligatoire dans la foulée d'une offre. Revue trimestrielle de droit financier, Paris, n. 3, 2006, p. 59). Tradução livre: "desprovida de qualquer autonomia, a retirada obrigatória é a consequência de uma oferta prévia, constituindo um complemento eventual. A operação em questão foi, no entanto, concebida pelo legislador como uma operação sui generis, não possuindo características que possam assimilá-la 
Para Olivier Douvreleur, conforme a seguir transcrito, apesar de suas características próprias, a retirada obrigatória pertence "à família das ofertas públicas":

\footnotetext{
"En dépit de ses caractères propres, le retrait obligatoire appartient bien à la 'famille des offres publiques', au moins sur le plan de sa mise en œuvre juridique et procédurale: sous l'un et l'autre de ses régimes, en effet, il est une opération toujours accessoire et consécutive à une offre publique qu'il vient achever $(\ldots)^{m 118}$.
}

De qualquer modo, embora esteja ligada a uma oferta pública de aquisição, a retirada obrigatória, como acima indicado, a ela não se assemelha. Dessa forma, como afirma Daniel Ohl, o direito aplicável deveria ser "non celui des offres publiques, mais le droit de l'expropriation",119.

A segunda delas se refere ao fato de a retirada obrigatória afetar o direito de propriedade, direito fundamental da pessoa e o direito de todo sócio de não ser excluído da sociedade. Diante da existência desses direitos e da obrigação imposta aos minoritários de cederem seus valores mobiliários, numerosos foram os estudos doutrinários a respeito da matéria em questão ${ }^{120}$.

Daniel Ohl apresenta, da maneira abaixo indicada, a controvérsia surgida acerca da legalidade da retirada obrigatória, com fundamento no artigo 545 do Código Civil francês ${ }^{121}$ :

juridicamente à oferta pública: ela resulta não da aceitação de uma oferta, mas de uma transferência obrigatória de valores mobiliários, mediante o pagamento de uma indenização".

${ }^{118}$ DOUVRELEUR, Olivier. Offres publiques: typologie et caractères. In: CANIVET, Guy; MARTIN, Didier; MOLFESSIS, Nicolas (Org.). Les offres publiques d'achat. Paris: Litec, 2009, p. 349. Tradução livre: "Apesar de suas características próprias, a retirada obrigatória pertence à 'família das ofertas públicas', ao menos no que se refere à sua aplicação jurídica e procedimental. Trata-se de uma operação acessória e consecutiva à oferta pública a ser concluída (...)".

119 OHL, Daniel. Droit des sociétés cotées. 3. ed. Paris: Litec, 2008, p. 324. Tradução livre: "não aquele das ofertas públicas, mas o direito da expropriação".

${ }^{120}$ Por exemplo: A. PIENTRACOSTA. Offre publique de retrait et retrait obligatoire. Dict. Joly Bourse, 2000-1 e SALOMON, R.; GERMAIN, M. Offre publique de retrait et retrait obligatoire. Actes prat. Ing. Sociétaire, $\mathrm{n}^{\circ} 61,2002$, p. 6.

${ }^{121}$ Dispõe o artigo 545 do Código Civil francês que "nul ne peut être contraint de céder sa propriété, si ce n'est pour cause d'utilité publique, et moyennant une juste et préalable indemnité". Tradução livre: "Ninguém pode ser obrigado a ceder sua propriedade, exceto se por causa de utilidade pública e mediante justa e prévia indenização". 
"Les minoritaires doivent se défaire de leurs titres, quand les majoritaires le leur demandent. Leur droit de rester associé est nié comme leur droit de propriété, puisqu'ils sont expropriés. L'expropriation ne peut se recommander de l'intérêt général, puisque le groupe majoritaire exerce son droit d'imposer le retrait aux minoritaires lorsqu'il y trouve son propre intérêt. Ce groupe n'a même pas à se soucier de l'intérêt de la société émettrice, puisqu'il n'agit pas comme organe social habilité à exprimer la volonté de la collectivité, mais en tant qu'actionnaire. Il poursuit des fins privées, non un but social”122.

Ocorre que a liceidade da retirada obrigatória encontra-se pacificada. Trata-se de uma medida de interesse geral, pois, dentre outros motivos, a concentração de valores mobiliários em apenas "uma mão" afetaria a liquidez do mercado. Por tal razão a C. cass. $^{123}$ valida a mencionada obrigação imposta aos minoritários, que receberão, nas palavras de Daniel Ohl, "un prix en rapport avec la valeur du bien"124.

122 OHL, Daniel, op. cit., p. 324. Tradução livre: “Os minoritários devem se desfazer de seus valores mobiliários, quando requerido pelos majoritários. O direito dos minoritários de permanecer na sociedade é negado, assim como seu direito de propriedade, já que são expropriados. A expropriação em questão não se fundamenta na proteção do interesse geral, já que o grupo majoritário exerce seu direito de impor a retirada aos minoritários quando tal medida for ao encontro do seu próprio interesse. Mencionado grupo não precisa, também, se preocupar com o interesse da sociedade emissora, porque ele não age como órgão social habilitado a exprimir a vontade da coletividade, mas como acionista, perseguindo fins privados e não um objetivo social"'.

${ }^{123}$ Por exemplo, C. cass., 29.04.97: D. 1998, jurispr., p. 334, nota de M.-A. Frison-Roche e M. Nussenbaum. ${ }^{124}$ OHL, Daniel, op. cit., p. 324. Tradução livre: "um preço relacionado com o valor do bem". 


\section{CAPÍTULO 3 \\ OFERTA PÚBLICA PARA AQUISIÇÃo DO CONTROLE DE COMPANHIA ABERTA NA FRANÇA}

\subsection{Introdução.}

Erik Frederico Oioli afirma que, desde a década de 1960, há, no mundo, um movimento cada vez mais intenso de transferência de titularidade do controle das companhias, tendo tal movimento se intensificado no Brasil, a partir da década de $1990^{125}$.

O mesmo movimento se intensificou também nos países europeus, embora seja evidente, como já mencionado, que com relação às OPA, por exemplo, o movimento foi mais relevante nos EUA e, após, pouco a pouco, foi progredindo na Europa. Esse é o entendimento de Martine Kloepfer-Pelèse, a respeito da evolução de tais operações:

\footnotetext{
"Bien que ces opérations soient soumises aux fluctuations économiques et que l'observation de l'évolution annuelle de ces transactions mette en évidence leur caractère cyclique, l'on assiste sans surprise, compte tenu des intérêts en jeu et à mesure que le phénomène de globalisation économique prend de l'ampleur, tout d'abord aux Etats-Unis à partir du début des années 1980, puis peu à peu dans l'ensemble des pays européens tels que la France, non seulement à leur forte progression, en volume comme en valeur, mais également, depuis les années 1990, à leur internationalisation, faisant définitivement prendre à ces opérations le virage de la mondialisation"
}

Será analisado o procedimento referente à OPA, na França, bem como as regras gerais a ela relativas. Antes disso, todavia, será definido o poder controle, à luz do direito francês e do direito brasileiro, e serão estudadas, de maneira breve, as demais formas de aquisição do controle interno das companhias abertas, sendo necessário, em tal ocasião,

\footnotetext{
${ }^{125}$ OIOLI, Erik Frederico, op. cit., p. 79.

${ }^{126}$ KLOEPFER-PELÈSE, Martine, op. cit., p. 10. Tradução livre: "Embora essas operações estejam sujeitas às flutuações econômicas e apesar de a observação da evolução anual dessas transações evidenciar seu caráter cíclico, assiste-se sem surpresa, considerando os interesses em jogo e à medida que o fenômeno da globalização econômica ganha importância, inicialmente nos Estados Unidos a partir da década de 1980 e, após, gradualmente em todos os países europeus, como a França, não apenas à forte progressão de tais operações, tanto em volume como em valor, mas igualmente, desde a década de 1990, à sua internacionalização, fazendo com que elas se inserissem definitivamente na mundialização".
} 
apontar os casos de aplicação da oferta pública obrigatória, de acordo com o direito francês.

\subsection{Poder de controle.}

\subsubsection{Tipologia.}

Fábio Konder Comparato diferencia dois grandes centros de poder na sociedade anônima - a saber: controle interno e controle externo ${ }^{127}$. Tendo em vista os objetivos deste trabalho, será analisado o controle interno.

Complementa o autor em questão que a definição do poder de controle interno, na sociedade anônima, é realizada sempre em função da assembleia geral, pois é ela o órgão primário ou imediato da sociedade anônima, que investe todos os demais e constitui a última instância decisória ${ }^{128}$.

A respeito das espécies de manifestação do poder de controle verificadas nas sociedades anônimas modernas, Fábio Konder Comparato se refere à consagrada relação de Berle e Means (cinco categorias ${ }^{129}$ ) e, em seguida, faz a sua releitura, conforme a realidade nacional ${ }^{130}$, reduzindo a quatro categorias - a saber: controle totalitário, controle majoritário, controle minoritário, controle gerencial ou administrativo ${ }^{131}$.

O controle totalitário ocorre quando nenhum acionista é excluído do poder de dominação da sociedade (seja sociedade unipessoal, seja companhia com controle totalitário conjunto), sendo, pois, a característica desse controle as decisões tomadas por unanimidade ${ }^{132}$.

127 COMPARATO, Fábio Konder; SALOMÃO FILHO, Calixto. O poder de controle na sociedade anônima. 5. ed. Rio de Janeiro: Editora Forense, 2008, p. 48.

${ }^{128}$ Idem, p. 51.

${ }^{129}$ São elas: controle com quase completa propriedade acionária; controle majoritário; controle obtido mediante expedientes legais; controle minoritário; controle gerencial.

${ }^{130}$ PATELLA, Laura Amaral. Poder de controle. Seminário apresentado, em 31 de agosto de 2010, na disciplina DCO 5886 - Teoria geral do direito societário II, do curso de pós-graduação da Faculdade de Direito da Universidade de São Paulo.

131 COMPARATO, Fábio Konder; SALOMÃO FILHO, Calixto. O poder de controle na sociedade anônima. 5. ed. Rio de Janeiro: Editora Forense, 2008, p. 51 e seguintes.

${ }^{132}$ Idem, p. 59-60. 
O controle majoritário fundamenta-se na titularidade da maioria das ações com direito a voto de uma companhia. Fábio Konder Comparato responde à pergunta "mas por que a maioria deve comandar?" da seguinte forma: "Parte-se, sem dúvida, do postulado de que a sociedade existe no interesse dos sócios, e como ninguém, em princípio, está investido da prerrogativa de decidir pelos interesses alheios, prevalece sempre a vontade do maior número, julgando cada qual segundo o seu próprio interesse" ${ }^{\Perp 133}$. O controle majoritário é classificado em simples ou absoluto, segundo exista ou não uma minoria qualificada, nos termos da lei ${ }^{134}$.

Fala-se em controle minoritário quando o controle é exercido com menos da metade das ações com direito a voto de uma companhia. O fenômeno em questão torna-se possível com a diluição do capital e o absenteísmo nas assembleias gerais ${ }^{135}$. Segundo Erik Frederico Oioli, esse fenômeno é cada vez mais frequente, em razão da acentuação da diferença entre acionistas empresários e acionistas capitalistas ou investidores, pois estes objetivam investir capital sob a administração alheia com o intuito de auferir renda e aqueles têm efetivo interesse na condução da empresa e os últimos objetivam ${ }^{136}$.

O controle administrativo ou gerencial não tem como fundamento a participação acionária, mas as prerrogativas dos administradores da companhia. Segundo Fábio Konder Comparato, em razão da "extrema dispersão acionária, os administradores assumem o controle empresarial de facto, transformando-se num órgão social que se autoperpetua por cooptação" ${ }^{\prime 137}$.

Como dito anteriormente, é preciso, para a realização da OPA, que a companhia seja de capital disperso, ou seja, quando há controle interno minoritário, gerencial ou ausência de controle ${ }^{138}$.

133 COMPARATO, Fábio Konder; SALOMÃO FILHO, Calixto. O poder de controle na sociedade anônima. 5. ed. Rio de Janeiro: Editora Forense, 2008, p. 60.

${ }^{134}$ Idem, p. 60-63.

${ }^{135}$ OIOLI, Erik Frederico, op. cit., p. 35.

${ }^{136}$ Idem, ibidem.

137 COMPARATO, Fábio Konder; SALOMÃO FILHO, Calixto. O poder de controle na sociedade anônima. 5. ed. Rio de Janeiro: Editora Forense, 2008, p. 71.

${ }^{138}$ A respeito da dispersão do capital, afirma Erik Frederico Oioli: “(...) quanto maior a dispersão do capital, maior a separação entre a propriedade e o controle. É a partir da configuração do poder de controle que se pretende definir o que seja uma companhia de capital disperso. Assim, serão sempre consideradas companhias de capital disperso aquelas cujo controle interno seja diluído ou gerencial. Trata-se de critério de mais fácil verificação do que a contagem de determinado número de acionistas. Basta que, definindo-se por 


\subsubsection{Conceito.}

Muitos doutrinadores afirmam que as dificuldades na conceituação do poder controle se devem, principalmente, ao seu elemento fático dominante e à sua constante mutação ${ }^{139}$.

Fábio Konder Comparato esclarece que a concepção do controle deve ser diferente quando, para a aplicação de uma disciplina, é necessária a consolidação de uma posição jurídica ${ }^{140}$. Exemplo disso é a disciplina da alienação de controle e da oferta pública $^{141}$.

Conquanto exista, no direito francês, como será analisado a seguir, previsão legal sobre o poder de controle, não foi deixado, no que se refere às OPA, ao ofertante a tarefa de escolher o que, a seu ver, constituiria o controle ${ }^{142}$. Isso porque, em princípio, a OPA deve ser total, ou seja, deve englobar todas as ações de emissão da companhia, tenham elas direito a voto ou não (art. 231-6 do RG da AMF) ${ }^{143}$.

Com relação à previsão legal, o artigo L. 233-3, I, do C. com. dispõe que uma sociedade é considerada controladora de outra quando: detém diretamente ou indiretamente uma fração do capital social que lhe confira maioria dos direitos de voto nas assembleias gerais $\left(1^{\circ}\right)$; dispõe sozinha da maioria dos direitos de voto em razão de um acordo (não contrário ao interesse social) concluído com outros acionistas $\left(2^{\circ}\right)$; determina de fato, pelos

exclusão, o controle interno não seja majoritário ou totalitário. Assim, uma companhia de capital disperso deverá ter, no mínimo, três acionistas com direito a voto, que seria o mínimo necessário para a configuração do controle diluído. Se a companhia tiver apenas dois acionistas com direito a voto, três são os cenários possíveis, conforme a posição acionária de cada um: poderá haver controle totalitário (decisões tomadas por unanimidade), controle majoritário (por exemplo, acionistas com $60 \%$ e $40 \%$ do total das ações com direito a voto) ou mesmo a ausência de controle, quando houver empate nas decisões assembleares (cada um dos acionistas com 50\% do capital social com direito a voto)" (OIOLI, Erik Frederico, op. cit., p. 38).

139 PATELLA, Laura Amaral, op. cit.

140 COMPARATO, Fábio Konder; SALOMÃO FILHO, Calixto. O poder de controle na sociedade anônima. 5. ed. Rio de Janeiro: Editora Forense, 2008, p. 70.

${ }^{141}$ Idem, ibidem.

${ }^{142}$ CHABERT, Pierre-Yves ; Couret, Alain. Les offres de prises de contrôle. In: CANIVET, Guy; MARTIN, Didier; MOLFESSIS, Nicolas (Org.). Les offres publiques d'achat. Paris: Litec, 2009, p. 276.

${ }^{143}$ Assim o explica Pierre-Yves Chabert: “(...). Il n'est pas apparu souhaitable de laisser à la volonté des acteurs la maîtrise de ce que pouvait constituer à leurs yeux le contrôle. Aussi, le principe posé est que, exception faite des offres publiques dites simplifiée, toute offre publique doit être tendue vers l'acquisition du contrôle et plus précisément vers l'acquisition de l'intégralité du contrôle" (Idem, ibidem). Tradução livre: "Não pareceu desejável deixar livre a definição de controle. Assim, o princípio é que, com exceção das ofertas públicas simplificadas, toda oferta pública deve se destinar à aquisição do controle e, mais precisamente, à aquisição da integralidade do controle". 
direitos de voto que dispõe, as decisões assembleares $\left(3^{\circ}\right)$; é acionista da sociedade e possui o poder de nomear ou revogar a maioria dos membros dos órgãos de administração, de direção ou de surveillance da sociedade $\left(4^{\circ}\right)$.

Dominique Schmidt entende que as assembleias gerais são regidas pela lei da maioria e, assim, o controle é a expressão do poder majoritário ${ }^{144}$. Diante disso, considerando que o poder é ligado ao direito de voto, o controle exprime o poder resultante da detenção de um número majoritário de votos. Essa é a regra, que não abrange todas as situações $^{145}$. Em determinados casos, até mesmo referidos na lei, o controle pertence a alguém que detém um número minoritário de votos, por exemplo. Logo, ao lado do controle majoritário, há o controle minoritário.

Alguns textos fazem uma ligação entre o controle e a maioria absoluta dos direitos de voto, como o artigo L. 233-3, I, $2^{\circ}$, do C. com. e outros entre o controle e a maioria relativa, como o artigo L. 233-3, I, $1^{\circ}$, do C. com.

Uma pessoa que detenha um número minoritário de votos em assembleia geral pode, em alguns casos, obter o controle seja sozinha ou em conjunto. É o caso do disposto no artigo L. 233-3, I, $3^{\circ}$, do C. com. O artigo em questão trata da determinação de fato das deliberações assembleares, que ocorre, porque o acionista não possui a maioria dos direitos de voto, mas a deliberação foi determinante, porque os demais acionistas não votaram contra $^{146}$.

Há, ainda, previsão quantitativa a partir da qual se determina presunção a respeito do poder de controle na sociedade. Nesse sentido, o artigo L. 233-3, II, do C. com. prevê que se presume que a sociedade exerce o controle quando ela dispõe direta ou indiretamente de uma fração dos direitos de voto superior a $40 \%$ e nenhum outro sócio ou acionista detém direta ou indiretamente fração superior à sua. A referida presunção do poder de controle estabelecida pelo artigo L. 233-3, II, do C. com. está fundamentada no fato de haver absenteísmo e dispersão dos demais acionistas ${ }^{147}$.

\footnotetext{
144 SCHMIDT, Dominique. Les définitions du contrôle d'une société. Revue de jurisprudence commerciale, Paris, n. 11 (especial), 1998, p. 10.

${ }^{145}$ Idem, ibidem.

${ }^{146}$ Idem, ibidem.

${ }^{147}$ Idem, p. 11.
} 
Por fim, dispõe o artigo L. 233-3, III, do C. com. que duas ou mais pessoas que agem em conjunto são consideradas controladoras de uma sociedade quando determinam de fato as decisões tomadas em assembleia geral.

No direito brasileiro, o artigo 116, caput, da LSA define o acionista controlador como sendo:

\footnotetext{
“(...) a pessoa natural ou jurídica, ou grupo de pessoas vinculadas por acordo de voto, ou sob controle comum, que: (a) é titular de direitos de sócio que lhe assegurem, de modo permanente, a maioria dos votos nas deliberações da assembléia-geral e o poder de eleger a maioria dos administradores da companhia; e (b) usa efetivamente seu poder para dirigir as atividades sociais e orientar o funcionamento dos órgãos da companhia".
}

Segundo o artigo $243, \S 2^{\circ}$, da LSA, considera-se "controlada a sociedade na qual a controladora, diretamente ou por meio de outras controladas, é titular de direitos de sócio que lhe assegurem, de modo permanente, preponderância nas deliberações sociais e o poder de eleger a maioria dos administradores".

As redações de ambos os dispositivos se assemelham, já que adotam como essência o fato de o acionista ou a sociedade controladora ser titular de direito de sócio que lhe assegure, de forma permanente, a preponderância nas deliberações sociais e o poder de eleger a maioria dos administradores ${ }^{148}$.

A diferença reside na alínea "b" do caput do artigo 116 da LSA, que dispõe que o acionista controlador deve usar efetivamente seu poder para dirigir as atividades sociais e orientar o funcionamento dos órgãos da companhia. Assim, o poder de controle não decorre somente das relações de direito, mas pressupõe o exercício efetivo, a ser analisado com base nas relações de fato ${ }^{149}$.

\footnotetext{
${ }^{148}$ NASCIMENTO, João Pedro Barroso do, op. cit., p. 18.

${ }^{149}$ Idem, p. 19.
} 


\subsection{Modalidades de aquisição do controle interno de companhias abertas.}

Existem diversas formas de se adquirir o controle interno de companhias abertas, no direito francês, assim como no direito brasileiro. Considerando, contudo, que o tema central deste trabalho se refere ao estudo da OPA, serão analisadas as três modalidades utilizadas com maior frequência para se adquirir o controle interno de companhia aberta de modo voluntário e oneroso.

\subsubsection{Escalada acionária.}

No direito francês, assim como no direito brasileiro, a escalada acionária é definida como uma série de aquisições de pequenos blocos de ações em bolsa de valores, por meio das quais o adquirente reunirá, sob sua propriedade, ações com direito a voto em quantidade suficiente para lhe assegurar o poder de controle.

Roberta Nioac Prado define a escalada acionária da seguinte forma:

\footnotetext{
“A escalada em Bolsa de Valores é um mecanismo de aquisição de controle societário que consiste na aquisição progressiva, em Bolsa de Valores (Mercado Secundário) e, eventualmente, em contratações privadas com acionistas minoritários, de participações acionárias votantes de emissão da companhia aberta cujo controle se pretende adquirir, pela pessoa, ou grupo de pessoas, físicas ou jurídicas, até que esta(s) adquira(m) número suficiente de ações com direito a voto para efetivamente exercer o controle desta companhia aberta" ${ }^{\$ 150}$.
}

Em princípio, o mecanismo ora analisado visa a, de uma forma discreta, surpreender os acionistas e administradores da companhia visada no que se refere à tomada do controle.

Ocorre que diversos inconvenientes inerentes ao mecanismo em questão podem levar ao insucesso da operação. Naturalmente quanto mais próximo o adquirente estiver do controle, maior será o preço das ações de emissão da companhia colocadas à venda no mercado, e o processo de escalada ser oneroso para o adquirente ${ }^{151}$.

\footnotetext{
${ }^{150}$ PRADO, Roberta Nioac, op. cit., p. 70.

${ }^{151}$ Idem, p. 71.
} 
Outro inconveniente se refere ao fato de que os administradores da companhia, ao perceberem a possível tomada do controle pelo adquirente, podem adotar medidas defensivas para evitar que isso ocorra, e as ações podem, ainda, deixar de serem ofertadas para venda no mercado secundário ${ }^{152}$. Assim, além de oneroso, o processo de escalada é incerto $^{153}$

Apesar das desvantagens acima referidas, o direito francês regula a escalada acionária, mediante a imposição legal de uma OPA (obrigatória) a posteriori ${ }^{154}$, a fím de evitar prejuízos aos acionistas minoritários ${ }^{155}$.

Com a Lei $\mathrm{n}^{\mathrm{o}}$ 2010-1249, de 22 de outubro de 2010, chamada de "Lei de regulação bancária e financeira", a OPA a posteriori é prevista no artigo L. 433-3, I, do C. mon. fin. Antes disso, o mencionado dispositivo do C. mon. fin., de maneira breve, se contentava em fazer remissão ao RG da $\mathrm{AMF}$, o qual precisava as condições e os efeitos da oferta pública em questão. De forma inesperada, quando dos trabalhos preparatórios do que viria a ser a "Lei regulação bancária e financeira", decidiu-se inserir no C. mon. fin. o que até então constava do RG da AMF. Dessa maneira, os elementos característicos da OPA $a$ posteriori são, atualmente, detalhados no C. mon. fin., reforçando o fundamento legal da referida oferta pública ${ }^{156}$.

O novo artigo L. 433-3, I, do C. mon. fin. prevê duas hipóteses que caracterizam, nas palavras de Paul Didier, "la montée en puissance" $" 157$ de um acionista, obrigando-o a realizar uma OPA a posteriori, que vise à totalidade do capital social e que seja direcionada aos demais acionistas. A primeira delas se refere ao fato de se adquirir, em conjunto ou isoladamente, direta ou indiretamente, mais de $30 \%$ do capital ou dos direitos

\footnotetext{
${ }^{152}$ PRADO, Roberta Nioac, op. cit., p. 71.

${ }^{153}$ Idem, ibidem.

${ }^{154}$ A Lei brasileira regula a OPA a posteriori, no artigo 254-A da LSA. Importa notar que apesar de as expressões usadas serem as mesmas, a OPA a posteriori do artigo 254-A da LSA é realizada em decorrência da alienação privada do controle de companhia aberta e a OPA a posteriori regulada pelo artigo L. 433-3 do C. mon. fin. é realizada, de acordo com percentuais de detenção do capital social ou dos direitos de voto, definidos em lei.

${ }^{155}$ Daniel Ohl vai mais longe ao mencionar que o direito positivo francês não é a favor da escalada acionária. Assim, afirma mencionado autor, "pour éviter un traitement inégal des minoritaires, le ramassage est encadré de telle manière qu'il ne puisse permettre de prendre le contrôle d'une société cotée" (OHL, Daniel, op. cit., p. 279). Tradução livre: "para evitar um tratamento desigual dos minoritários, a escalada acionária é enquadrada, para que não se permita a tomada de controle de uma companhia aberta".

${ }^{156}$ DIDIER, Paul; DIDIER, Philippe, op. cit., p. 1102-1103.

${ }^{157}$ Idem, p. 1103.
} 
de voto. A segunda hipótese se refere ao aumento significativo de uma participação ao longo de um ano ${ }^{158}$. Aquele que detiver, direta ou indiretamente, entre 30 e $50 \%$ do capital social ou dos direitos de voto da companhia deverá obrigatoriamente realizar uma OPA $a$ posteriori, se, em 12 meses consecutivos, sua participação no capital ou nos direitos de voto da companhia aumentou em, ao menos, $2 \%^{159}$, sob pena de perder seus direitos de voto (art. 433-3, I, do C. mon. fin.).

A OPA a posteriori é um mecanismo que, além de regular e limitar a liberdade das partes, concede proteção aos minoritários, sendo justificável sua aplicação, na opinião de Philippe Didier, quando a aquisição de valores mobiliários resultar na modificação da estrutura do controle da companhia. Nesse sentido, Philippe Didier afirma o que segue:

\begin{abstract}
“(...), le règlement de l'AMF prévoit un certain nombre d'aménagements. En effet, l'offre obligatoire est un mécanisme de protection des minoritaires. C'està-dire qu'elle ne doit jouer que lorsqu'il se produit une modification de la structure de contrôle de la société. Or il se peut aussi que les acquisitions de titres n'aboutissent pas à modifier cette structure de contrôle. C'est notamment le cas lorsque l'opération est menée par un actionnaire qui est d'ores et déjà en situation de contrôler la société. Dans ce cas la situation des minoritaires n'est pas modifiée. Dès lors, il n'y a pas lieu d'imposer une OPO [offre publique obligatoire]. Le règlement général prévoit une palette de situation dans lesquelles, l'initiateur de l'opération est dispensé de déposer une OPO"160.
\end{abstract}

Ocorre que a lei não fala em modificação do controle. Em princípio, os fundamentos para a realização da OPA a posteriori são o percentual do capital social e dos direitos de voto adquiridos, bem como o tempo gasto com mencionada aquisição, podendo, obviamente, após isso, o adquirente assegurar o controle.

\footnotetext{
${ }^{158}$ Considerando que a Lei $\mathrm{n}^{\circ}$ 2010-1249, de 22 de outubro de 2010, inseriu os elementos característicos da OPA a posteriori no C. mon. fin., o RG da AMF, atualmente, em seus artigos 234-2 e 234-5, não precisaria mais repetir o determinado pelo citado diploma legal com relação às hipóteses de cabimento da mencionada oferta pública obrigatória.

${ }^{159}$ DIDIER, Paul; DIDIER, Philippe, op. cit., p. 1103.

${ }^{160}$ Idem, p. 1105. Tradução livre: “(...), o regulamento da AMF prevê certos temperamentos. A oferta obrigatória é um mecanismo de proteção dos minoritários, ou seja, ela é realizada apenas quando há uma modificação na estrutura do controle. Pode ocorrer de as aquisições de valores mobiliários não gerarem tal mudança. É o caso, por exemplo, da operação realizada por um acionista que já detém o controle. Nessa hipótese, a situação dos minoritários não é modificada, não sendo necessária a imposição de uma OPO [oferta pública obrigatória]. O regulamento geral prevê uma série de situações em que o ofertante fica dispensado de protocolar um projeto de OPO".
} 
Ademais, existe, no direito francês, uma complexa regulamentação a respeito do dever de disponibilizar informações aos investidores e ao mercado no que se refere, por exemplo, à aquisição de ações que representem certo percentual do capital social ou dos direitos de voto ${ }^{161}$. Nesse sentido, aquele que, em conjunto ou isoladamente, detiver ações que, por exemplo, representem mais de $5,10,15,20,25,30,33,33$ 50, 66,66, 90 ou 95\% do capital ou dos direitos de voto deve informar a companhia da participação em questão (art. L. 233-7, I, al. 1, do C. com. e art. R. 233-1 do C. com.), bem como a AMF (art. 22314 do RG da AMF), que disponibilizará referida informação ao público (art. L. 233-7, II, do C. com.). No caso de descumprimento da referida obrigação, aplicam-se sanções de natureza penal (art. L. 247-2, I, do C. com.; $18000 €$ de multa) e civil (art. L. 233-14 C. com.). Além disso, mediante requerimento do presidente da sociedade, de um acionista ou da AMF, o Tribunal de Comércio pode declarar a suspensão total ou parcial dos direitos de voto do acionista que descumpriu as obrigações de declaração (art. L. 233-14 do C. com.) ${ }^{162}$.

Dispõe, ainda, o artigo 234-5, al. 2, do RG da AMF que aquele que, em conjunto ou isoladamente, detiver entre 30 e $50 \%$ do capital ou dos direitos de voto de uma companhia deve manter a AMF informada das variações referentes ao percentual do capital social ou dos direitos de voto por ele detidos, e a AMF deve publicar tais informações.

Além do dever de informar, quando uma pessoa física ou jurídica adquire ações que representem mais de $10,15,20$ ou $25 \%$ do capital ou dos direitos de voto de uma companhia, é necessária a apresentação de uma declaração de intenção ${ }^{163}$ que indique, sobretudo, seus objetivos para os seis meses subsequentes (art. L. 233-7, VII do C. com. e art. R. 233-1-1 do C. com.) ${ }^{164}$. No caso de mudança de intenção dentro de seis meses, uma nova declaração deve ser realizada. Aplicam-se as sanções civis e penais impostas ao

\footnotetext{
${ }^{161}$ Trata-se de um dos dispositifs d'alerte, conforme estudado no item 4.1.2.2.

${ }^{162}$ COZIAN, Maurice; VIANDIER, Alain; DEBOISSY, Florence. Droit des sociétés. 25. ed. Paris: Litec, 2012, p. 765.

${ }^{163}$ A não apresentação da declaração em questão acarretará a aplicação de sanção, em consonância com o artigo L. 233-14, al. 3, do C. com.

${ }^{164} \mathrm{O}$ legislador francês vai além e prevê que podem os estatutos determinar uma obrigação suplementar de informação referente à detenção de ações que represente determinado percentual do capital ou dos direitos de voto, percentual esse inferior a 5\% e superior a 0,5\% (art. L. 233-7, III, do C. com.). A esse respeito afirma Philippe Merle: "Cette possibilité est très utilisée par les sociétés qui ont un actionnariat très 'atomisé' et dont elles veulent suivre l'évolution pour se prémunir contre des attaques de "prédateurs"' (MERLE, Philippe. Droit commercial: sociétés commerciales. 14. ed. Paris: Dalloz, 2010, p. 865). Tradução livre: "Essa possibilidade é muito utilizada pelas sociedades que possuem um grupo 'atomizado' de acionistas e cuja evolução é monitorada de perto para proteção contra ataques de "predadores"”.
} 
descumprimento da obrigação de informação acima prevista (art. L. 233-14 do C. com. e art. L. 247-2, I, do C. com.). Com isso, nota-se que a finalidade principal do legislador francês é garantir um tratamento igualitário aos acionistas na alienação de seus valores mobiliários (OPA a posteriori). Existe, ainda, a preocupação com a disponibilização ao mercado e aos investidores de informações relativas às aquisições de ações que, por exemplo, podem, em algum momento, representar alteração no controle societário.

A Instrução CVM n ${ }^{\circ} 358$, de 3 de janeiro de 2002, em seu artigo 12, prevê que os acionistas controladores, diretos ou indiretos, e os acionistas que elegerem membros do conselho de administração ou do conselho fiscal, assim como qualquer pessoa natural ou jurídica ou grupo de pessoas, que atingirem participação, direta ou indireta, que corresponda a $5 \%$ ou mais de espécie ou classe de ações representativas do capital de companhia aberta devam enviar à companhia diversas informações, como nome e qualificação do adquirente, o objetivo da participação e a quantidade visada.

Apesar disso, não existe, na legislação brasileira ${ }^{165}$, qualquer solução semelhante à acima descrita no que se refere à obrigação de realização de uma OPA a posteriori ${ }^{166}$, tornando a dispersão do capital, nas palavras de Erik Frederico Oioli, "um facilitador à

\footnotetext{
${ }^{165}$ Erik Frederico Oioli enfatiza a insuficiência da legislação e da autorregulação brasileiras no que se refere à proteção contra escaladas acionárias. Lembra, contudo, o autor em questão o que segue: "Convém notar, contudo, que operações em bolsa que impliquem grandes oscilações na quantidade ou cotação das ações normalmente negociadas devem ser realizadas segundo procedimento especial de leilão. Tal procedimento, de acordo com o Regulamento de Operações da Bolsa de Valores do Estado de São Paulo, requer publicidade e, caso se verifique que o lote de ações objeto do leilão seja suficiente para a aquisição do controle de companhia aberta visada, a operação não deveria ser cursada em bolsa e, sim, processada nos termos do artigo 257 e seguintes da Lei das Sociedades Anônimas. Poder-se-ia eventualmente argumentar pela autonomia da vontade das partes (caso houvesse aceitação pelos acionistas destinatários de procedimento alternativo para aquisição do controle em bolsa) e dispensar-se a aplicação dos dispositivos da LSA para as ofertas públicas para aquisição do controle. Não parece ser correto tal posicionamento" (OIOLI, Erik Frederico, op. cit., p. 83).

${ }^{166}$ Isso porque a escalada em bolsa não impõe ao adquirente uma obrigação de realizar OPA a posteriori pelas ações dos demais acionistas minoritários, inexistindo a distribuição de prêmio pelo controle aos acionistas. Assim, nas palavras de Erik Frederico Oioli "o artigo 254-A da LSA determina que referida OPA ocorra somente nos casos de 'alienação, direta ou indireta, do controle de companhia aberta' (destaque nosso). $\mathrm{O} \S 1^{\circ}$ do referido artigo ainda dispõe que 'entende-se como alienação de controle a transferência, de forma direta ou indireta, de ações integrantes do bloco de controle, de ações vinculadas a acordo de acionistas (...)' (destaque nosso) entre outros. A lei, ao definir a obrigatoriedade da OPA, olha para o polo do alienante do controle, pressupondo que quem aliena já possuía o poder de controle. Ora, a escalada acionária é uma forma de aquisição originária do poder de controle, pois, não ocorrendo a transferência de nenhuma ação do bloco de controle, não há que se falar em alienação de controle" (Idem, p. 69). As hipóteses de aplicação da OPA a posteriori no direito francês são mais amplas, diferindo, pois, da OPA a posteriori existente no direito brasileiro.
} 
aquisição do controle por terceiros, que em situação inversa - de concentração de capital seriam obrigados a negociar com o controlador e a pagar prêmio pelo controle" ${ }^{\text {167 }}$.

Aponta Erik Frederik Oioli que a recente evolução das estruturas do mercado de capitais e o desenvolvimento da autorregulação são fundamentais para a criação de condições estruturais e regulatórias que visem tornar realidade a dispersão do capital ${ }^{168}$. No entanto, a falta de disciplina adequada à escalada em bolsa de valores, nas palavras do referido autor, "ainda põe em risco o fenômeno da dispersão acionária",169.

A solução acima descrita do direito francês poderia ser adaptada e adotada no Brasil. Em outras palavras, deveria ser obrigatória a realização de uma OPA a posteriori, caso fosse atingido determinado percentual do capital social, percentual esse a ser analisado com mais vagar em estudo específico sobre o tema. Além disso, o direito brasileiro deveria aprimorar, a exemplo do legislador francês, a obrigação de informação, tornando, por exemplo, obrigatória a realização de nova declaração, quando houver mudança no que se refere ao objetivo da participação.

\subsubsection{Aquisição privada.}

Tradicionalmente, a aquisição do controle interno de companhia aberta é realizada de maneira amigável, através da celebração de um contrato de compra e venda de ações entre o acionista controlador alienante e o adquirente do controle. Nesse contrato, são estabelecidos, por exemplo, o número de ações a serem alienadas em quantidade suficiente para assegurar ao adquirente o controle, bem como o preço a ser atribuído a esse bloco.

Diferentemente da escalada acionária, uma das vantagens da modalidade em questão consiste na segurança em se adquirir o controle dentro do prazo previsto. A principal desvantagem da operação se refere ao alto custo em razão do prêmio pelo controle a ser pago ao alienante. Além disso, a operação torna-se inviável, caso o acionista controlador se oponha à negociação de compra e venda das ações representativas do controle.

\footnotetext{
${ }^{167}$ OIOLI, Erik Frederico, op. cit., p. 69.

${ }^{168}$ Idem, p. 68.

${ }^{169}$ Idem, ibidem.
} 
Na França, existem disposições legais expressas que visam a obrigar a oferta pública total de aquisição de ações dos minoritários, nas hipóteses de alienação do controle de companhia aberta.

Historicamente, antes de 1973, existia no RG da Companhia dos Corretores um procedimento denominado maintien de cours. Havendo aquisição na bolsa de valores de um "bloco de controle", o adquirente do mencionado bloco deveria comprar na bolsa de valores, pelo mesmo preço, as ações que lhe fossem apresentadas por um determinado período $^{170}$. Em 1973, a fim de estender mencionado procedimento a quaisquer formas de tomada de controle, principalmente para abranger as aquisições de controle realizadas hors bourse, a COB publicou uma decisão geral, indicando que as cessões de blocos de ações conferindo o controle de companhia aberta ou fechada deveriam ser realizadas conforme o princípio da igualdade de tratamento entre todos os acionistas, mesmo quando tais cessões não estivessem submetidas ao Regulamento Geral da Companhia dos Corretores, como é notadamente o caso de mudança de controle de companhia fechada ${ }^{171}$.

No ano de 1989, a importante Lei $n^{\circ}$ 89-531, de 2 de agosto, além introduzir, no direito francês, a oferta pública de aquisição obrigatória e a oferta pública de retirada, introduziu, ainda, o procedimento de garantie de cours, o qual obrigava aquele que obtivesse a aquisição de um bloco ${ }^{172}$ de valores mobiliários a propor aos demais acionistas minoritários da companhia a aquisição de seus valores mobiliários, respeitados o preço e as condições contratados com o adquirente do controle.

A existência do referido procedimento era, há muito tempo, discutida, no direito francês, pois o seu campo de aplicação abrangia aquele da OPA a posteriori ${ }^{173}$.

\footnotetext{
${ }^{170}$ Segundo Roger Houin, o objetivo do procedimento em questão consistia em assegurar a igualdade dos acionistas, por meio da obrigação imposta ao adquirente do bloco de controle consistente em transferir o preço fixado no ato de cessão a qualquer outro acionista que se apresentasse dentro de certo prazo - HOUIN, Roger. La prise de contrôle d'une société par actions (à l'exclusion du contrôle des concentrations d'entreprise). Revue internationale de droit comparé, Paris, n. 2, 1986, p. 573.

${ }^{171}$ Disponível em: 〈http://www.amf-france.org/documents/general/3592 1.pdf >, p. 36. Acesso em: 15.07.11.

${ }^{172}$ VIANDIER, Alain, op. cit., p. 389.

${ }^{173}$ Philippe Merle ensina que "pendant longtemps, lorsqu'une société cotée changeait de contrôle, se posait le problème de la protection des actionnaires minoritaires, dès lors que les parties n'utilisaient pas la procédure d'offre publique. En 1998, une procédure spéciale de garantie de cours a été instaurée en vue d'assurer le respect du principe d'égalité entre les différents actionnaires. Cependant, la question du maintien de cette procédure s'est posée depuis que toute offre publique doit porter sur la totalité du capital. Finalement, la loi de régulation bancaire et financière du 22 octobre 2010, prenant acte de ce que la garantie de cours avait été absorbée par l'offre obligatoire, a décidé son abrogation". Tradução livre: "durante muito tempo persistiu o
} 
Apesar de muitos defenderem a manutenção da garantie de cours, o legislador de 2010 preferiu, nas palavras de Paula Didier, "simplifier le dispositif des offres de protection des minoritaires et il a purement et simplement supprimé la procédure de garantie de cours" $" 174$.

A decisão do legislador francês foi acertada pelos motivos, a seguir indicados: (i) pela segurança jurídica resultante da eliminação do procedimento da garantie de cours, pois conforme acima mencionado, havia casos em que tanto o procedimento em questão quanto a OPA a posteriori aplicavam-se, em princípio; (ii) o preço, na garantie de cours, era o mesmo que aquele pago pela aquisição do bloco de valores mobiliários que conferia a participação majoritária no capital social ou nos direitos de voto da companhia, podendo ser inferior ao maior valor pago pelo adquirente pelos valores mobiliários objeto da oferta, no período de 12 meses que a antecedesse. Logo, o preço na garantie de cours podia ser inferior àquele enunciado pelo artigo 234-6 do RG da AMF relativo à oferta pública obrigatória. Esse artigo transpôs a noção de "preço justo", constante da Diretiva $n^{\circ}$ 2004/25/CE.

Com o fim do procedimento da garantie de cours, aplicam-se, também, à aquisição privada do controle interno de companhia aberta as regras atinentes à OPA $a$ posteriori acima examinadas.

No Brasil, onde a OPA a posteriori é legalmente obrigatória, um terceiro alheio ao controle poderá adquiri-lo, após negociação prévia e acordo entre as partes, incidindo, pois, o artigo 254-A da LSA.

Roberta Nioac Prado afirma, conforme abaixo transcrito, que mencionada espécie de OPA a posteriori possui como objetivo regular e limitar a liberdade das partes, bem

problema da proteção dos acionistas minoritários, quando as partes não utilizavam o procedimento da oferta pública. Em 1998, um procedimento especial de garantie de cours foi instituído, com o objetivo de assegurar o respeito do princípio da igualdade entre os diferentes acionistas. No entanto, a questão da manutenção do procedimento em questão foi suscitada, já que a OPA passou a ser obrigatoriamente total e, finalmente, a Lei de regulação bancária e financeira, de 22 de outubro de 2010, considerou que a garantie de cours foi absorvida pela oferta obrigatória, decidindo suprimi-la" (MERLE, Philippe. Droit commercial: sociétés commerciales. 15. ed. Paris: Dalloz, 2012, p. 846).

${ }^{174}$ DIDIER, Paul; DIDIER, Philippe, op. cit., p. 1102. Tradução livre: "simplificar as disposições relativas às ofertas de proteção dos minoritários, tendo simplesmente suprimido o procedimento de garantie de cours". 
como assegurar tratamento igualitário aos acionistas detentores de ações da mesma espécie e classe.

\begin{abstract}
"Fundamentalmente, esta espécie de OPA legalmente obrigatória tem como objetivo regular e limitar a liberdade das partes nas cessões privadas de controle societário, assegurando aos demais acionistas da companhia participar do prêmio de controle pago ao acionista controlador"175.
\end{abstract}

\title{
3.3.3 Oferta pública para aquisição do controle de companhia aberta.
}

De acordo com Maurice Cozian, a OPA “est le moyen permettant de prendre le contrôle d'une société, généralement contre l'avis de ses dirigeants"176.

Como já mencionado, diferentemente do Brasil, onde a OPA deve ter por objeto ações com direito a voto em número suficiente para garantir o controle da companhia (art. 257, §2 ${ }^{\circ}$, da LSA) ${ }^{177}$, na França, o objeto da OPA é mais amplo, pois nele estão compreendidos, além das ações com e sem direito a voto, outros valores mobiliários, tais como as debêntures conversíveis em ações.

Outra diferença é que, na França, a OPA deve ser total, ou seja, deve englobar todas as ações de emissão da companhia, tenham elas direito a voto ou não (art. 231-6 do RG da $\mathrm{AMF})^{178}$.

Trata-se de uma das mais importantes formas de aquisição do controle societário de companhia aberta, desde que sejam criadas condições propícias ao seu surgimento, por meio da existência prévia de mercados nos quais o controle da companhia esteja diluído nas mãos de um grande número de acionistas ${ }^{179}$.

\footnotetext{
${ }^{175}$ PRADO, Roberta Nioac, op. cit., p. 77-78.

${ }^{176}$ COZIAN, Maurice; VIANDIER, Alain; DEBOISSY, Florence, op. cit., p. 760. Tradução livre: "é o meio que permite a tomada do controle de uma sociedade, geralmente contrariando a vontade dos administradores".

177 Complementa o artigo 257, §3º , que "se o ofertante já for titular de ações votantes do capital da companhia, a oferta poderá ter por objeto o número de ações necessário para completar o controle, mas o ofertante deverá fazer prova, perante a Comissão de Valores Mobiliários, das ações de sua propriedade".

${ }^{178}$ Segundo as lições de Thierry Bonneau, o fundamento para reforma da qual resultou a OPA total foi a igualdade de tratamento dos acionistas (BONNEAU, Thierry. La réforme des offres publiques d'acquisition, Bulletin Joly, 1992, p. 599).

${ }^{179}$ PRADO, Roberta Nioac. Análise crítica do instituto da oferta pública obrigatória, em decorrência da alienação do controle de companhia aberta, em face da realidade brasileira (artigo 254-A da Lei n.
} 
As vantagens da OPA são diversas, podendo ser citadas algumas relacionadas aos acionistas minoritários e outras relacionadas ao adquirente do controle.

No que se refere às primeiras, pode ser citado o fato de os acionistas minoritários receberem valor geralmente superior ao da cotação da bolsa, participando, pois, aqueles que aceitarem a oferta em igualdade de condições do eventual prêmio de controle ${ }^{180}$. Além disso, considerando o amplo disclosure necessário para a operação, podem os acionistas decidir acerca da pertinência ou não de continuar na companhia, que terá seu controle alterado $^{181}$.

Quanto às segundas, pode ser mencionado, o fato de a conclusão da OPA ser realizada de forma relativamente rápida ${ }^{182}$, o que poderá gerar como consequência para a companhia objeto a dificuldade de adoção, pela administração, de mecanismos de defesa, bem como a possibilidade de uma oferta, pela OPA, a todos os acionistas, sem que haja a necessidade de negociar com a administração ou com eventual acionista controlador ${ }^{183}$.

Por fim, existe também a vantagem que decorre da segurança que se concede ao adquirente do controle, já que, assim como no Brasil, na França, por meio do artigo 231-9

6.404, de 1976). São Paulo. 2004. Tese (Doutorado em direito). Faculdade de Direito, Universidade de São Paulo, p. 34.

${ }^{180}$ OIOLI, Erik Frederico, op. cit., p. 97.

${ }^{181}$ PRADO, Roberta Nioac, PRADO, Roberta Nioac. Análise crítica do instituto da oferta pública obrigatória, em decorrência da alienação do controle de companhia aberta, em face da realidade brasileira (artigo 254-A da Lei n. 6.404, de 1976). São Paulo. 2004. Tese (Doutorado em direito). Faculdade de Direito, Universidade de São Paulo, p. 37.

${ }_{182}$ Philippe Merle trata das vantagens da OPA, conforme a seguir indicando, e enfatiza, por exemplo, que a operação em questão possibilita a realização, de maneira rápida, de concentração e de reestruturação de empresas. Além disso, afirma o autor que acionistas minoritários e majoritários serão mantidos em situação de igualdade: "Les OPA-OPE présentent de nombreux avantages: elles permettent de réaliser rapidement des concentrations ou restructurations d'entreprises, à un prix fixé à l'avance, le même pour tous les actionnaires de la société visée, qui, majoritaires comme minoritaires, seront maintenus sur un strict pied d'égalité. La possibilité d'une telle opération doit inciter les dirigeants à gérer de façon stricte leur société pour que les actions ne soient pas sous-évaluées en bourse, et à 'fidéliser' (...). Les OPA permettent également d'animer le marché financier" (MERLE, Philippe. Droit commercial: sociétés commerciales. 14. ed. Paris: Dalloz, 2010, p. 823). Tradução livre: "As OPA-OPE apresentam inúmeras vantagens: elas permitem a rápida realização de concentrações ou reestruturações de empresas, a um preço previamente fixado e igual para todos os acionistas da companhia visada, acionistas esses que, majoritários como minoritários, serão mantidos em um nível de igualdade. A possibilidade de realização da mencionada operação deve encorajar os administradores a atuarem na companhia de maneira precisa, para que as ações de sua emissão não fiquem subvalorizadas na bolsa e, ainda, para a 'fidelização' dos acionistas (...). As OPA dão, também, vida ao mercado financeiro".

${ }^{183}$ OIOLI, Erik Frederico, op. cit., p. 97. 
do RG da AMF, existe a possibilidade de sujeitar a OPA à condição ${ }^{184}$ de aquisição de ações em determinado número que seja suficiente para lhe assegurar o poder de controle ${ }^{185}$.

Erik Frederico Oioli aponta, ainda, com relação à OPA no Brasil, as seguintes vantagens relacionadas ao custo da operação:

\begin{abstract}
“(...) Além disso, há uma relativa redução de custo para a aquisição do controle, uma vez que o ofertante pode adquirir apenas uma quantidade mínima de ações para obtê-lo. Também, o ofertante saberá de antemão o custo total da operação, por ter a oferta preço determinado" ${ }^{\text {186 }}$.
\end{abstract}

Conforme indicado, tais vantagens não se aplicam à OPA realizada na França. Isso porque, de acordo com o artigo 231-6 do RG da AMF, a OPA tem que ser, em regra, total, ou seja, deve abranger todas as ações de emissão da companhia aberta, tenham elas direito a voto ou não.

\title{
3.3.3.1 Procedimento.
}

É preciso destacar que a matéria ora analisada encontra-se em textos esparsos, sendo, por exemplo, necessária a análise do C. mon. fin. e do $\mathrm{RG}$ da $\mathrm{AMF}^{187}$.

\footnotetext{
${ }^{184}$ Daniel Ohl afirma que a liceidade de uma cláusula que submeta a OPA à condição de aquisição de ações em determinado número é facilmente compreensível, na medida em que o objetivo do ofertante é a tomada de controle da companhia visada ou a detenção de certa fração do capital social. Lembra o autor, ainda, que a cláusula em questão somente pode ser prevista no âmbito da OPA voluntária submetida ao procedimento normal (OHL, Daniel, op. cit., p. 274).

${ }^{185}$ OIOLI, Erik Frederico, op. cit., p. 97.

${ }^{186}$ Idem, ibidem.

${ }^{187}$ Assim entende Bertrand Durupt: "Le fait d'évoquer une procédure relative aux offres publiques devant l'Autorité des marchés financiers (AMF) peut donner à penser qu'il existe un corpus de règles régissant ladite procédure, voire même une codification de celle-ci, à l'instar par exemple du Code de procédure civile. Or, ces règles ne font pas l'objet de dispositions regroupées dans un texte législatif ou réglementaire. Il faut se référer au Code monétaire et financier, au règlement général et plus particulièrement dans ce dernier cas, au livre II ('Émetteurs et information financière'), titre III ('offres publiques d'acquisition'), ce dernier ne comportant pas de chapitre ou section portant spécifiquement sur la procédure d'offre publique" (DURUPT, Bertrand. La procédure d'offre publique devant l'Autorité des marchés financiers. In: CANIVET, Guy; MARTIN, Didier; MOLFESSIS, Nicolas (Org.). Les offres publiques d'achat. Paris: Litec, 2009, p. 15). Tradução livre: "O fato de invocar um procedimento relativo às ofertas públicas perante a Autoridade dos mercados financeiros (AMF) pode levar a crer que existe um conjunto de regras disciplinando mencionado procedimento ou mesmo uma codificação, apesar da existência do Código de processo civil. Ocorre que tais regras não foram reagrupadas em um texto legislativo ou regulamentar. É preciso se referir ao Código monetário e financeiro, ao regulamento geral e mais precisamente, neste último caso, ao livro II ('Emissores e informação financeira'), título III ('ofertas públicas de aquisição'), não existindo capítulo ou seção específica sobre o procedimento da oferta pública”.
} 


\subsection{Da apresentação do projeto de oferta à declaração de conformidade.}

Na França, o chamado projeto de oferta deve ser apresentado (protocolado), independentemente da modalidade de OPA, ou seja, de compra ou de permuta, concorrente ou não, por meio de instituição intermediária (instituição financeira), perante a AMF, para registro (“declaração de conformidade").

Essa é uma das diferenças com relação ao procedimento da OPA, no Brasil, onde, em regra, não é preciso registro prévio da OPA perante a $\mathrm{CVM}^{188}$, sendo necessário o encaminhamento do edital ao diretor de relações com investidores da companhia objeto, para que este divulgue imediatamente ao mercado, através de sistema eletrônico disponível na página da CVM na rede mundial de computadores ${ }^{189}$. Ademais, como será estudado adiante, o procedimento na França é marcado por uma maior presença da AMF, que deve, até mesmo, decidir sobre a conformidade da OPA com as normas legislativas e regulamentares, bem como sobre a participação da companhia objeto no procedimento, por meio da elaboração da nota em resposta.

A fim de evitar que tais "intervenções" tornem o procedimento excessivamente longo e devido à necessária rapidez da operação, foram fixados prazos relativamente curtos de manifestação de cada parte envolvida.

A citada presença da AMF pode ser verificada, por exemplo, pela elaboração de um complexo calendário da OPA. Youssef Djehane ensina que a determinação do referido calendário da OPA é importante para se restabelecer o equilíbrio entre o ofertante, a companhia visada, seus acionistas e eventuais ofertantes concorrentes, já que o ofertante possui certas vantagens. É o caso, por exemplo, da "quase neutralização" 190 dos poderes dos administradores da companhia visada que geralmente ocorre com o protocolo da

\footnotetext{
${ }^{188}$ No entanto, é obrigatório o registro perante a CVM, no caso de oferta de permuta (art. 259 da LSA; arts. $2^{\circ}$, $1^{\circ}$, e $9^{\circ}$ da Instrução CVM n n $^{\circ} 61 / 02$ ). Havendo uma OPA concorrente, esta, segundo o artigo 13 da Instrução CVM n $361 / 02$, "observará as regras aplicáveis à modalidade de OPA em que se enquadrar", bem como o disposto no artigo em questão.

${ }^{189}$ Complementa, ainda, o artigo $11, \S 2^{\circ}$, da Instrução CVM n ${ }^{\circ}$ 361/02 que o edital fica, também, disponível "a eventuais interessados, no mínimo, na CVM, na bolsa de valores ou na entidade do mercado de balcão organizado em que deva ser realizado o leilão, no endereço do ofertante, na sede da instituição intermediária e da companhia objeto, bem como acessível na rede mundial de computadores, no endereço eletrônico da companhia objeto, se esta o possuir".

190 DJEHANE, Youssef. Le calendrier des offres publiques. In: CANIVET, Guy; MARTIN, Didier; MOLFESSIS, Nicolas (Org.). Les offres publiques d'achat. Paris: Litec, 2009, p. 462.
} 
oferta. Dessa forma, o calendário da OPA, além de garantir a realização ordenada da oferta e de fazer com que as partes diretamente interessadas tomem decisões em prazos compatíveis com o princípio de urgência, que governa o funcionamento do mercado, tem como objetivo limitar a vantagem conferida ao ofertante com relação ao calendário ${ }^{191}$.

A apresentação do projeto de oferta se faz por meio de uma carta ${ }^{192}$ endereçada à AMF e assinada por, ao menos, uma instituição intermediária, que garantirá, conforme aponta o artigo 231-13 do RG da AMF, "o conteúdo e o caráter irrevogável dos compromissos assumidos pelo ofertante". A carta em questão deve ser acompanhada de outros documentos. É o caso, por exemplo, do projeto de nota de informação elaborado pelo ofertante ${ }^{193}$, sozinho ou em conjunto ${ }^{194}$.

A AMF publicará as principais disposições constantes do projeto de oferta. A data da mencionada publicação marca o início do chamado "período da oferta"195, o qual se encerrará com a publicação do resultado da oferta.

Operíodo da oferta é importante, por diversos motivos. Primeiramente, porque marca o início do prazo que a AMF terá para apreciar os documentos protocolados e a conformidade do projeto de oferta com as disposições legislativas e regulamentares em vigor $^{196}$, qual seja, de dez jours de négociation ${ }^{197}$. Se o projeto de oferta e os documentos apresentados estiverem em consonância com as exigências dos artigos 231-21 e 231-22 do RG da AMF, esta publicará em seu endereço eletrônico uma declaração de conformidade

\footnotetext{
${ }^{191}$ DJEHANE, Youssef, op. cit., p. 451.

192 Art. 231-13, al. 2, do RG da AMF.

${ }^{193}$ Do referido projeto de nota de informação deve constar, por exemplo: a identidade do ofertante; o conteúdo de sua oferta; suas intenções para o período de 12 meses com relação à política industrial e financeira das sociedades consideradas; suas orientações em matéria de emprego (art. 231-18 do RG da AMF).

194 Normalmente, a mencionada elaboração será em conjunto, quando se tratar de uma oferta pública amigável. Mas, como lembra Daniel Ohl, deverá ser feita separadamente, "dans le cas de 'conflit d'intérêts' visés à l'article 261-1 du Règlement général de l'AMF. En effet, dans ces hypothèses, il est formellement défendu à la société initiatrice et à la société visée d'établir un projet de note d'information conjoint, sauf en cas de retrait obligatoire (AMF, Règl. général, art. 231-13, al. 9)” (OHL, Daniel, op. cit., p. 289). Tradução livre: "no caso de 'conflito de interesses', mencionado pelo artigo 261-1 do Regulamento geral da AMF. Nessas hipóteses, não podem a sociedade ofertante e a sociedade visada elaborar em conjunto um projeto de nota de informação, exceto no caso de retirada obrigatória (AMF, Règl. général, art. 231-13, al. 9)".

${ }^{195}$ Artigo 231-14 do RG da AMF.

${ }^{196}$ Artigo 231-20, I, do RG da AMF.

${ }^{197} \mathrm{O}$ jour de négociation utilizado no RG da AMF corresponde ao pregão de bolsa.
} 
motivada, a qual implica a aprovação do projeto de nota de informação ${ }^{198}$. Caso contrário, ou seja, de não conformidade, a AMF decidirá motivadamente e publicará sua decisão em seu endereço eletrônico ${ }^{199}$. Além disso, o referido projeto de nota de informação deve ser colocado à disposição do público, na sede do ofertante, bem como em seu endereço eletrônico, quando existente, e junto das instituições financeiras ${ }^{200}$.

Quando elaborado juntamente com a companhia visada, o artigo 231-16, I, do RG da AMF, com o objetivo de informar os acionistas e os investidores, em geral, determina que o projeto de nota de informação seja disponibilizado também na sede da referida companhia, bem como em seu endereço eletrônico, quando existente.

A companhia objeto deve protocolar junto à AMF e publicar seu projeto de nota de informação em resposta àquela do ofertante, do qual constará, principalmente, o parecer do conselho de administração ou do conseil de surveillance, conforme o caso ${ }^{201}$, em um prazo de cinco jours de négociation, após a publicação pela AMF de sua decisão de conformidade.

Havendo a designação de um expert indépendant, em aplicação do artigo 261-1 do RG da AMF, a nota de informação em resposta ${ }^{202}$ deve ser protocolada, no máximo, em 20 jours de négociation, após o início do período da oferta ${ }^{203}$.

\footnotetext{
${ }^{198}$ Segundo aponta Daniel Ohl, o princípio do contraditório não se aplica a essa fase do procedimento. Nesse sentido afirma o autor citado: "Le principe du contradictoire n'est pas applicable à cette phase de la procédure en sorte que 'l'AMF n'est pas tenue d'auditionner les personnes qui en feraient la demande, ni de répondre aux observations ou à la demande de communications de pièces formulées par des personnes intéressées, comme par exemple les documents soumis à l'AMF et le rapport d'un expert indépendant"” (OHL, Daniel, op. cit., p. 288). Tradução livre: "O princípio do contraditório não se aplica a essa fase do procedimento, de modo que a 'AMF não precisa escutar as pessoas que o requeiram, tampouco responder às observações ou ao pedido de comunicação de documentos formulados por pessoas interessadas, como é o caso dos documentos a ela submetidos e o relatório do auditor independente"".

199 Artigo 231-23 do RG da AMF.

200 Artigo 231-16, I, do RG da AMF.

${ }^{201}$ A respeito da escolha do modelo de administração da sociedade ("sociedade anônima do tipo clássica” ou "sociedade dual"), ver nota de rodapé no 331.

${ }^{202}$ Conforme indica Daniel Ohl, a nota de informação em resposta deve conter o seguinte: uma apresentação da companhia, principalmente, no plano contábil e financeiro, bem como indicar a repartição do capital (OHL, Daniel, op. cit., p. 291). Ademais, a nota de informação do ofertante e a nota em resposta da companhia objeto, possuem uma condição comum, como explica Daniel Ohl: "À titre de condition commune, l'article 231-5 du Règlement général de l'AMF exige que toutes les notes d'information, qu'elles émanent de l'initiateur ou de la société cible, mentionnent les clauses des conventions prévoyant des conditions préférentielles de cession ou d'acquisition d'actions ainsi que toutes autres clauses comprises dans des conventions passés entre les sociétés concernées ou leurs actionnaires qui sont susceptibles d'avoir une incidence sur l'appréciation de l'offre publique ou sur son issue" (OHL, Daniel, op. cit., p. 289). Tradução livre: "A título de condição comum, o artigo 231-5 do Regulamento geral da AMF exige que todas as notas
} 
Com o intuito de dar credibilidade à nota de informação em resposta ${ }^{204}$, o expert indépendant (sem ligação com a administração da companhia) foi incumbido de apresentar sua opinião quanto à mencionada nota de informação em resposta (attestation d'équité) ${ }^{205}$. A presença do expert indépendant é necessária, quando a OPA puder acarretar conflito de interesse no conselho de administração ou no conseil de surveillance, prejudicando a objetividade do parecer dos mencionados órgãos ${ }^{206}$ ou comprometendo a igualdade dos $\operatorname{acionistas}^{207}$.

O artigo 261-1 do RG da AMF traz uma lista exemplificativa ${ }^{208}$ das hipóteses de obrigatoriedade do expert indépendant, em razão do conflito de interesse que geram e da ruptura da igualdade entre os acionistas ${ }^{209}$. O expert indépendant é designado pela companhia visada ${ }^{210}$, devendo ser imparcial e independente ${ }^{211}$.

Por fim, vale ressaltar que referida presença da AMF se nota, ainda, pelo fato de ela possuir o poder de exigir que uma pessoa esclareça suas intenções, caso existam motivos razoáveis indicando que prepara uma oferta pública ${ }^{212}$. Caso tal pessoa declare

de informação, sejam elas do ofertante ou da companhia visada, mencionem as cláusulas dos contratos que prevejam condições preferenciais de cessão ou de aquisição de ações, bem como todas as cláusulas compreendidas nos contratos celebrados entre as sociedades envolvidas na operação ou entre os seus acionistas que sejam suscetíveis de ter uma incidência na apreciação da oferta pública ou no seu resultado".

${ }^{203}$ Artigo 231-26, al. 1, do RG da AMF.

${ }^{204}$ Nesse sentido é a lição de Paul Didier, que trata do surgimento do papel do expert indépendant na OPA, nos seguintes termos: "Formellement la note en réponse est un document établi par la société cible. Les dirigeants s'y expriment non pas à titre personnel mais en qualité d'organes sociaux. Pour autant, le conflit d'intérêts structurel dans lequel sont les dirigeants d'une société objet d'une OPA affaiblit l'opinion qu'ils émettent dans la note en réponse. Aussi la pratique a cherché des moyens de 'crédibiliser' cette opinion" (DIDIER, Paul; DIDIER, Philippe. Droit commercial: les sociétés commerciales. t. 2. Paris: Economica, 2011, p. 1092). Tradução livre: "Formalmente a nota em resposta é um documento elaborado pela companhia visada, no qual a manifestação dos administradores não se dá a título pessoal e sim na qualidade de órgãos da sociedade. Por essa razão, o conflito de interesses estrutural no qual se encontram os administradores de uma sociedade objeto de uma OPA enfraquece a opinião emitida na nota em resposta. A prática procurou meios de dar 'credibilidade' à mencionada opinião".

${ }^{205} \mathrm{O}$ papel do expert indépendant vai mais longe, porquanto determina o artigo 262-1, I, do RG da AMF que ele deve elaborar um relatório sobre as condições financeiras da oferta.

${ }^{206}$ Parecer na nota em resposta, segundo o artigo 231-19, $4^{\circ}$, do RG da AMF.

${ }^{207}$ Artigo 261-1, I, do RG da AMF.

${ }^{208}$ Por exemplo, quando companhia visada for controlada pelo ofertante; quando os dirigentes da companhia visada ou seus controladores celebraram um acordo com o ofertante suscetível de afetar sua independência (Artigo 261-1, I, $1^{\circ}$ e $2^{\circ}$, do RG da AM).

$209 \mathrm{Na}$ opinião de Thierry Bonneau, considerando a lista ser exemplificativa, a presença do expert indépendant pode ser imposta em outros casos não previstos expressamente, possuindo a AMF uma margem de apreciação considerável a esse respeito (BONNEAU, Thierry. Expertise indépendante. Droit des sociétés, Paris, n. 7, 2006, p. 31).

${ }^{210}$ Artigo 261-1, I, do RG da AMF.

211 Artigo 261-4 do RG da AMF.

${ }^{212}$ Artigo 223-32 do RG da AMF. 
que tem a intenção de apresentar um projeto de oferta, a AMF fixará a data para que se publique um comunicado sobre as características do projeto de oferta ou, conforme o caso, para que ocorra o protocolo do projeto de oferta ${ }^{213}$. Contrariamente, se a pessoa declara não ter a intenção de apresentar um projeto de oferta, ela não poderá protocolá-lo, durante um período de seis meses, a contar de sua declaração, exceto se houver modificações na situação predominante à época da declaração, por exemplo ${ }^{214}$.

No direito brasileiro, não há a designação de um expert indépendant, mas quando se tratar de OPA formulada pela própria companhia, pelo acionista controlador ou por pessoa a ele vinculada, é necessária a instrução da OPA com laudo de avaliação da companhia, a fim de disponibilizar ao destinatário da oferta informações suficientes para a avaliação do preço oferecido ${ }^{215}$.

Existe, ainda, no direito francês, como na Diretiva $\mathrm{n}^{\mathrm{o}} 2004 / 25 / \mathrm{CE}^{216}$, uma preocupação com a informação e a participação dos trabalhadores na OPA. Com o protocolo do projeto de OPA, é preciso que seja "imediatamente" reunido o comitê de empresas da companhia visada, para informá-lo da operação em questão ${ }^{217}$. O mesmo deve ser realizado pelo ofertante com relação ao seu comitê de empresas, em dois dias úteis contados da publicação do projeto da oferta ${ }^{218}$. Além disso, o ofertante deve enviar ao comitê de empresas da companhia visada a nota de informação, o que não seria necessário, pois mencionado documento já foi tornado público, conforme acima verificado ${ }^{219}$.

A Lei $n^{\circ}$ 2001-420, de 15 de maio de 2001 e a Lei $n^{\circ}$ 2006-387, de 31 de março de 2006, complementaram os dispositivos de informação dos trabalhadores no que se refere a um ponto importante - a saber ${ }^{220}$ : possibilidade de o comitê de empresas da companhia visada convocar o ofertante, a fim de obter todos os esclarecimentos necessários sobre a

\footnotetext{
213 Artigo 223-33, al. 1, do RG da AMF.

214 Artigo 223-35, al. 1, do RG da AMF.

${ }^{215}$ OIOLI, Erik Frederico. Oferta pública de aquisição do controle de companhias abertas. São Paulo, 2008. Dissertação (Mestrado em Direito). Faculdade de Direito, Universidade de São Paulo, p. 123.

${ }^{216}$ Artigo $^{\circ}$ (1) da Diretiva ${ }^{\circ}$ 2004/25/CE.

${ }^{217}$ Artigo L. 2323-21, al. 1, do Code du travail.

${ }^{218}$ Artigo L. 2323-25, al. 2, do Code du travail.

219 Artigo L. 2323-22 do Code du travail.

${ }^{220}$ Artigo L. 2323-23 do Code du travail.
} 
operação ${ }^{221}$. Caso o ofertante não o faça, a sanção consiste na privação dos seus direitos de voto (os direitos que possui ou possuirá) ${ }^{222}$.

Finalmente, a apresentação e a realização de uma de OPA não ocasiona, em princípio, a suspensão da cotação das ações de emissão das companhias interessadas. No entanto, o presidente da AMF pode requerer a suspensão temporária da cotação dessas ações quando forem desrespeitadas algumas regras do mercado no qual se encontram cotadas as ações 223 .

\subsection{Da abertura ao encerramento da oferta.}

A abertura da oferta, cuja data é indicada no aviso da AMF a respeito do calendário da oferta ${ }^{224}$, ocorre a contar da realização de algum dos acontecimentos previstos no artigo 231-32 do $\mathrm{RG}$ da $\mathrm{AMF}^{225}$. Sobretudo em alguns setores da atividade, a abertura da oferta pode ser adiada até que ocorra o recebimento pela AMF das autorizações prévias necessárias, de acordo com a legislação em vigor.

A data de abertura da oferta é importante, pois, primeiramente, a partir dela, aqueles que desejarem aceitar a OPA podem enviar suas ordens de venda à instituição intermediária, conforme dispõe o artigo 231-33 do RG da AMF. E, também, é a partir da data de abertura da oferta que se inicia, por exemplo, o prazo para a realização de uma oferta concorrente, bem como o prazo para que o ofertante melhore as condições de sua oferta $^{226}$.

\footnotetext{
${ }^{221}$ Na prática, o ofertante, que, em princípio, precisaria ser ouvido, deverá, nas palavras de Alain Viandier, "principalement écouter", pois "il prend connaissance des observations du comitê" (VIANDIER, Alain, op. cot., p. 215). Tradução livre: "principalmente escutar", pois "ele toma conhecimento das observações do comitê".

${ }^{222}$ COZIAN, Maurice; VIANDIER, Alain; DEBOISSY, Florence, op. cit., p. 766.

${ }^{223}$ Artigo L. 421-15, I, do C. mon. fin.

${ }^{224}$ Dispõe o artigo 231-31 do RG da AMF que o calendário da oferta pública é fixado em função da data de publicação da nota de informação elaborada conjuntamente pelo ofertante e pela companhia visada ou da nota de informação em resposta elaborada pela companhia visada. A alínea $2^{\mathrm{a}}$ do artigo 231-32 do RG da AMF complementa que as datas de abertura, de encerramento e dos resultados são publicadas pela AMF.

${ }^{225}$ De acordo com o artigo 231-32 do RG da AMF, ela ocorre no dia seguinte: (i) à publicação da nota de informação elaborada pelo ofertante; ou em conjunto com a companhia objeto; ou da nota de informação em resposta, nos casos previstos no artigo 261-1 do RG da AMF; (ii) à publicação das informações mencionadas no artigo 231-28; (iii) ao recebimento pela AMF das autorizações prévias necessárias, segundo a legislação em vigor.

${ }^{226}$ Artigos 232-5 e 232-6 do RG da AMF.
} 
O artigo 232-7 do RG da AMF dispõe que a oferta concorrente e a melhoria das condições da oferta pelo ofertante deverão ser lançadas por preço, no mínimo, $2 \%$ superior da OPA com que concorrer ou da oferta inicial ${ }^{227}$.

Vale, por fim, salientar que o procedimento acima estudado se aplica, em princípio, à OPA concorrente e à melhoria das condições da oferta pelo primeiro ofertante. É necessário que a AMF declare a conformidade do respectivo projeto de oferta ${ }^{228}$. A AMF verifica, também, segundo o artigo 232-7, al. 2, do RG da AMF, se a oferta implicará significativa melhora das condições propostas aos titulares de valores mobiliários envolvidos.

A duração de uma OPA é de, em média, 25 jours de négociation ${ }^{229}$, podendo, contudo, a AMF $\operatorname{adiar}^{230}$ ou mesmo antecipar ${ }^{231}$ a data do encerramento da OPA. Nesse caso, a decisão da AMF é submetida ao eventual controle do judiciário.

Na prática, lembra Youssef Djehane que a AMF utiliza seu poder de adiar o encerramento da OPA, no caso de recursos judiciais ou quando a OPA tem como objeto ações cotadas em diferentes mercados regulamentados ${ }^{232}$.

Considerando, conforme acima analisado, a possibilidade de OPA concorrente e de melhoria da proposta pelo ofertante, o artigo 433-1-1 do C. mon. fin. determina que cabe à AMF fixar uma data definitiva de encerramento de todas as ofertas, quando mais de três meses se passaram desde o protocolo do projeto de oferta ${ }^{233}$. Em princípio, o resultado

\footnotetext{
${ }^{227}$ Ver item 3.3.3.2.3., a respeito da legislação brasileira sobre o assunto em questão.

${ }^{228}$ Importante notar que a OPA concorrente ocasiona automaticamente uma mudança no calendário da OPA com que concorrer. Assim dispõe o artigo 232-10, al. 1, do RG da AMF.

${ }^{229}$ Artigo 232-2 do RG da AMF.

${ }^{230}$ Artigo 231-34 do RG da AMF.

${ }^{231}$ Entende Youssef Djehane que, com o objetivo de preservar o equilíbrio entre os diferentes protagonistas da oferta, a AMF pode, em certos casos definidos pelo seu regulamento geral, antecipar ou adiar a data do encerramento da oferta. Logo, ela dispõe de um poder geral de apreciação que lhe permite, durante a oferta e segundo as circunstâncias, adiar a data de encerramento (DJEHANE, Youssef, op. cit., p. 460). Por exemplo, dispõe o artigo 231-30 do RG da AMF que "la date de clôture de l'offre peut, sur décision de l'AMF, être reportée pour que les détenteurs de titres disposent au minimum d'un délai de cinq jours de négociation pour se prononcer après la publication de l'information mentionnée à l'article 231-29". Tradução livre: "a data de encerramento da oferta pode, por decisão da AMF, ser adiada, a fim de que os detentores de títulos disponham, no mínimo, de um prazo de cinco dias de negociação para se pronunciarem após a publicação da informação mencionada no artigo 231-29".

${ }^{232}$ DJEHANE, Youssef, op. cit., p. 461.

${ }^{233}$ Artigos 232-12 e 232-13 do RG da AMF.
} 
da oferta é publicado, no máximo, nove jours de négociation após a data de encerramento da $\mathrm{OPA}^{234}$.

Outra particularidade da legislação francesa, se comparada com a brasileira, é a de que, caso a OPA se concretize, sua reabertura ocorre automaticamente nos dez jours de négociation, após a publicação do resultado definitivo ${ }^{235}$. O caráter irrevogável da OPA também se aplica quando da sua reabertura, como disposto expressamente pelo artigo 2324, al. 2, do RG da AMF. O calendário dessa oferta, que possui duração de, ao menos, dez jours de négociation, será publicado pela $\mathrm{AMF}^{236}$. Trata-se de um mecanismo que concede, por exemplo, aos acionistas não convencidos em aceitar a OPA a possibilidade de se retirarem da companhia, por meio da reabertura da operação, pouco importando que o ofertante tenha atingido o percentual de $95 \%$ do capital e dos direitos de voto da companhia $^{237}$. Sobre isso discorre Youssef Djehane:

\footnotetext{
"Lorsque l'offre s'est déroulée selon la procédure normale et connaît une suite positive, sa réouverture intervient automatiquement, le plus souvent dès le lendemain de la publication des résultats définitifs de l'offre et, en tout état de cause, dans un délai maximum de dix jours de négociation suivant la publication du résultat définitif et pour une durée minimale de dix jours de négociation (...). Cette réouverture intervient même si l'initiateur a atteint, au terme de la première période d'offre, le seuil de $95 \%$ du capital et des droits de vote lui permettant de mettre en œuvre un retrait obligatoire immédiatement après son offre. Ce dispositif permet aux actionnaires non totalement convaincus par l'offre et/ou prêts à soutenir la cible dans sa défense, de ne pas apporter leurs titres, tout en bénéficiant de l'assurance, au cas où l'offre serait néanmoins couronnée de succès, de pouvoir in fine apporter leurs titres et ainsi bénéficier de la prime et de la liquidité offertes",238.
}

\footnotetext{
${ }^{234}$ Artigo 232-3 do RG da AMF.

235 Artigo 232-4, al. 1, do RG da AMF.

${ }^{236}$ Artigo 232-4, al. 3, do RG da AMF.

${ }^{237}$ Dessa forma, não se questiona a realização de uma oferta pública de retirada.

${ }^{238}$ DJEHANE, Youssef, op. cit., p. 462. Tradução livre: “Quando a oferta pública se realizou segundo o procedimento normal e tendo sido a oferta bem sucedida, sua reabertura frequentemente ocorre desde o dia seguinte ao da publicação dos resultados definitivos e, em todo caso, dentro de um prazo máximo de 10 dias de negociação após a publicação do referido resultado e durante um período mínimo de 10 dias negociação (...). Essa reabertura ocorre mesmo se o ofertante atingiu, após o primeiro período da oferta, o limite de $95 \%$ do capital e dos direitos de voto, o que lhe permitiria realizar a retirada obrigatória imediatamente após sua oferta. Esse mecanismo permite que os acionistas não totalmente convencidos pela oferta e/ou prontos para apoiarem a companhia visada na sua defesa não participem da oferta, mas se beneficiem da garantia, caso a oferta seja bem sucedida, consistente na cessão dos seus títulos, beneficiando-se do prêmio e da liquidez oferecidos".
} 
Esse mecanismo é relevante, de um lado, pois permite, com a reabertura da OPA, ao minoritário vender suas ações. Por outro lado, é preciso lembrar que o minoritário já teve a oportunidade de fazê-lo. Assim, conceder-lhe outra oportunidade significa para a companhia custo com todo o procedimento que envolve a operação, podendo ir de encontro aos seus interesses.

O legislador brasileiro acertadamente abrangeu na reforma da Instrução CVM n ${ }^{\circ}$

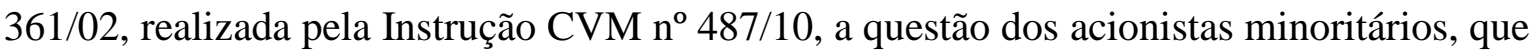
não participaram da OPA, ao prever, no o artigo 32-A, que o ofertante, exceto no caso de OPA parcial, ficará obrigado a adquirir, após a OPA, as ações em circulação remanescentes da mesma espécie e classe, pelo prazo de 30 dias, contado da data da realização do leilão, pelo preço final da OPA. Trata-se de um mecanismo mais simples que a reabertura da OPA, tal como existente no direito francês, e que possibilita alcançar o mesmo resultado.

\subsubsection{Regras gerais.}

Faz-se necessária a análise de alguns aspectos relacionados à instituição intermediária; às consequências da apresentação do projeto de oferta sobre o funcionamento do mercado; ao projeto de oferta e à oferta condicional.

\subsection{Instituição intermediária.}

Como já descrito, o protocolo do projeto de oferta é realizado perante a AMF através do chamado présentateur de l'offre, ou seja, por uma instituição financeira, que participará de toda a operação.

Laurent Faugérolas aponta que, além de seu tradicional papel de aconselhar, a instituição intermediária age com três qualidades. Logo, nas palavras do autor em questão, a instituição intermediária é: “(i) mandataire de son client pour un certain nombre de formalités (dépôt de l'offre publique, relations avec l'Autorité des marchés financiers, 
notamment) ${ }^{239}$; (ii) transmetteur d'ordres sur le marché et (iii) garant de la bonne fin de l'opération" 240 .

Autorizado pelo artigo 1985 do Código Civil francês, o mandato é celebrado geralmente sob a forma de uma carta, na qual o ofertante, nas palavras de Alain Viandier, determina que se proceda à compra das ações da companhia visada no âmbito do procedimento da $\mathrm{OPA}^{241}$. Ademais, contém a carta diversas instruções sobre o preço, a quantidade de ações, etc.

De acordo com o artigo 2004 do Código Civil francês, o mandante pode revogar o mandato, a qualquer momento. Aplicando essa regra às OPA, surgem algumas consequências, tais como: necessária substituição do primeiro mandatário; não caducidade da decisão de conformidade da $\mathrm{AMF}^{242}$.

No que tange à responsabilidade da instituição financeira, é preciso analisá-la, primeiro, com relação ao contrato de mandato e, após, com relação à garantia por ela assumida. No primeiro caso, a responsabilidade é analisada, levando-se em conta o fato de o mandato ser oneroso ${ }^{243}$. Segundo o artigo 1991 do Código Civil francês, a instituição financeira deve executar o mandato e responderá pelos danos resultantes de sua inexecução ${ }^{244}$. Complementa o artigo 1992 do Código Civil francês que o mandatário

\footnotetext{
${ }^{239}$ São aplicáveis à mencionada relação as disposições constantes dos artigos 1984 e seguintes do Código Civil francês.

${ }^{240}$ FAUGÉROLAS, Laurent; DUPONT-JUBIEN, André. Le rôle et les obligations des établissements présentateurs. In: CANIVET, Guy; MARTIN, Didier; MOLFESSIS, Nicolas (Org.). Les offres publiques d'achat. Paris: Litec, 2009, p. 498. Tradução livre: “(i) mandatária de seu cliente para uma série de formalidades (protocolo do projeto de oferta pública, relações com a Autoridade dos mercados financeiros, notadamente); (ii) transmissora de ordens no mercado e (iii) garantidora da conclusão bem sucedida da operação".

${ }^{241}$ VIANDIER, Alain, op. cit., p. 186.

${ }^{242}$ Idem, ibidem.

${ }^{243}$ Isso porque, segundo o artigo 1992, al. 2, do Código Civil francês, a responsabilidade é aplicada menos rigorosamente se o mandato é gratuito, diferentemente do que ocorre se há o recebimento de um "salário".

${ }^{244}$ Afirma Laurent Faugérolas que a jurisprudência acerca da responsabilidade das instituições intermediárias é de pouca importância. No entanto, é preciso mencionar a decisão da CA de Paris, de 10 de março de 2006, que precisou os limites da obrigação do mandatário, em especial, na hipótese de uma oferta pública de permuta. Assim o explica o autor em questão: "Cet arrêt vient préciser les limites de l'obligation de l'établissement mandataire, en particulier dans le cadre d'une offre publique d'échange. Si celui-ci 'doit contrôler l'obligation qui est faite à l'initiateur de présenter à l'assemblée générale extraordinaire de ses actionnaires, un projet de résolution visant à décider l'émission de titres, aux clauses et conditions prévues par l'offre publique, ... il n'est pas tenu de procéder à la vérification des conditions dans lesquelles l'assemblée générale des actionnaires de [la société initiatrice] a été convoquée"' (FAUGÉROLAS, Laurent; DUPONT-JUBIEN, André, op. cit., p. 505-506). Tradução livre: "Essa decisão precisa os limites da obrigação da instituição financeira, particularmente, no âmbito de uma oferta pública de permuta. Se a
} 
responde não apenas pelo dolo, mas também pelos atos culposos cometidos durante a sua gestão $^{245}$. No entanto, a função da instituição financeira vai mais longe, pois ela aconselha o ofertante e determina juntamente com ele os elementos da oferta, podendo, até mesmo, propor-lhe a companhia visada. A responsabilidade da instituição financeira pode, então, decorrer do dever de aconselhar, o qual não é estranho ao mandato ${ }^{246}$. Trata-se uma obrigação de meio ${ }^{247}$.

Existe solidariedade entre as diferentes instituições intermediárias, em razão da

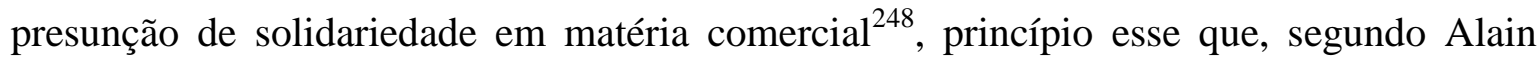
Viandier, permite afastar a aplicação da regra segundo a qual quando há diversos mandatários, a solidariedade entre eles existe apenas quando expressamente prevista (artigo 1995 do Código Civil francês) ${ }^{249}$.

Com relação à garantia, afirma Pierre Bézard que a função conferida à instituição intermediária é fundada na preocupação de "s'assurer du sérieux de la démarche de l'initiateur" ${ }^{250}$. Assim, a garantia não se refere apenas ao aspecto financeiro, mas também à conformidade da oferta com a legislação em vigor ${ }^{251}$. A garantia a ser concedida pela instituição intermediária consta do artigo 231-13 do RG da AMF, que determina que o protocolo do projeto de oferta seja realizado por uma ou mais instituição financeira, através de carta endereçada à AMF garantindo, "sous la signature d'au moins un des établissements présentateurs, la teneur et le caractère irrévocable des engagements pris par l'initiateur". Dessa forma, conforme dispõe o artigo 231-13, al. 2, do RG da AMF, a instituição financeira deve garantir o caráter irrevogável dos compromissos assumidos pelo ofertante, responsabilizando-se pessoal e diretamente, nos casos de falta de pagamento do preço de compra das ações.

\footnotetext{
instituição financeira 'deve controlar a obrigação de submeter à assembleia geral de acionistas um projeto de resolução que vise à emissão de valores mobiliários de acordo com as cláusulas e condições previstas pela oferta pública, a ela não cabe verificar as condições nas quais a assembleia geral de acionistas [da sociedade ofertante] foi convocada"”.

${ }^{245}$ Segundo decisão da CA de Paris, responde o mandatário por um ato desleal (CA Paris, 30.09.05).

${ }^{246}$ VIANDIER, Alain, op. cit., p. 187.

${ }^{247}$ C. cass., 03.10.95.

${ }^{248}$ C. cass. civ., 18.07.29.

${ }^{249}$ VIANDIER, Alain, op. cit., p. 188.

${ }^{250}$ BÉZARD, Pierre, op. cit., p. 64. Tradução livre: "garantir a seriedade da iniciativa do ofertante".

${ }^{251}$ VIANDIER, Alain, op. cit., p. 187-188.
} 
Apesar de certa discussão ${ }^{252}$ quanto à natureza jurídica da garantia, a maioria entende que se trata de uma garantia autônoma, constante do artigo 2321 do Código Civil, cujo objeto se limita aos termos e ao caráter irrevogável dos compromissos assumidos pelo ofertante $^{253}$.

A duração da garantia, que deve ser prestada pela instituição financeira, vai do momento em que a oferta adquire o caráter irrevogável (ou seja, da declaração de conformidade $^{254}$ ) até sua efetivação, podendo, contudo, tal garantia chegar ao seu fim antecipadamente, em decorrência de alguns acontecimentos, como ensina Laurent Faugérolas:

\begin{abstract}
"Dans le silence de la réglementation, une partie de la doctrine considère que l'offre ne devient irrévocable qu'à compter de la décision de recevabilité, ce qui permettrait à la société de retirer son offre pendant toute la durée de l'instruction du dossier effectuée par l'AMF. La garantie prend naturellement fin en cas de décision de non-conformité de l'offre. Enfin, la garantie prend fin dans tous les cas où le règlement général $\mathrm{AMF}$ permet à la société initiatrice de revenir sur ses engagements, que ce soit par l'insertion de conditions suspensives (obtention d'un certain seuil, accord des autorités de concentration, autorisation de l'assemblée générale extraordinaire des actionnaires ou par la consécration d'un droit de repentir (en cas d'offre ou surenchère concurrente ou modification de la consistance de la société cible) ${ }^{\text {,255. }}$.
\end{abstract}

No Brasil, é necessária a participação de instituição financeira na OPA, visando a garantir o cumprimento das obrigações assumidas pelo ofertante ${ }^{256}$. A instituição financeira não é, como no caso do direito francês, ligada ao ofertante por meio de um mandato, e suas obrigações e responsabilidades são detalhadamente disciplinadas. Prova disso é o artigo $7^{\circ}, \S 2^{\circ}$, da Instrução CVM n $361 / 02$, que dispõe que a instituição

\footnotetext{
${ }^{252}$ Alguns autores entendem que se trata de um contrato de fiança (BÉZARD, Pierre, op. cit., p. 65). A crítica que se faz é que a instituição financeira garante, em razão do RG da AMF e não em razão de um contrato (VIANDIER, Alain, op. cit., p. 188).

${ }^{253}$ OHL, Daniel. Droit des sociétés cotées. 3. ed. Paris: Litec, 2008, p. 288.

${ }^{254}$ Há discussão sobre o momento em que a oferta se torna irrevogável. Ver item 3.3.3.2.3.

${ }^{255}$ FAUGÉROLAS, Laurent; DUPONT-JUBIEN, André, op. cit., p. 503-504. Tradução livre: "no silêncio da regulamentação, parte a doutrina considera que a oferta se torna irrevogável a contar da decisão de conformidade, o que permitiria à sociedade retirar sua oferta durante toda a duração da instrução do processo efetuada pela AMF. A garantia termina no caso de declaração de não conformidade da oferta e nos casos em que o regulamento geral AMF permite à sociedade ofertante mudar de posição com relação aos seus compromissos, seja pela inserção de condições suspensivas, seja pela consagração de um direito ao arrependimento".

${ }^{256}$ Artigo 257, caput, da LSA.
} 
intermediária deverá tomar todas as cautelas e agir com elevados padrões de diligência, a fim de assegurar que as informações fornecidas pelo ofertante sejam verdadeiras, consistentes, corretas e suficientes, respondendo pela omissão nesse seu dever e devendo, também, verificar a suficiência e a qualidade das informações fornecidas ao mercado durante todo o procedimento da OPA.

Complementa o $\S^{\circ}$ do mesmo artigo que a instituição intermediária deverá ajudar o ofertante em todas as fases da OPA, bem como dele requerer a prática dos atos necessários ao correto desenvolvimento da oferta e a cessação de atividades que prejudiquem referido desenvolvimento, devendo interromper seus serviços na hipótese de recusa do ofertante, sob pena de não se eximir das responsabilidades impostas na Instrução em questão.

Dispõe o $\S^{\circ}$ do citado artigo que a instituição intermediária deve garantir a liquidação financeira da OPA e o pagamento do preço de compra.

Com relação à natureza dessa garantia, para alguns autores, como Modesto Carvalhosa, a instituição financeira atua como "obrigada solidária" pelo cumprimento da oferta voluntária, em consonância com a redação do caput do artigo 257 da LSA. Assim, a oferta terá como obrigados o ofertante e a instituição financeira, devendo esta garantir o pagamento do valor ofertado ${ }^{257}$.

Mas, como bem lembra Erik Frederico Oioli, o artigo 265 do Código Civil brasileiro dispõe que a solidariedade não se presume, dependendo de Lei ou da vontade das partes. Além disso, o artigo 257 da LSA em nenhum momento afirma haver solidariedade entre o ofertante e a instituição intermediária, se limitando a dizer que a instituição financeira deve garantir a oferta, sendo, pois, a obrigação da instituição intermediária subsidiária à do ofertante ${ }^{258}$.

${ }^{257}$ CARVALHOSA, Modesto. Comentários à lei das sociedades anônimas. v. 4. 4. ed. São Paulo: Saraiva, 2009, p. 218.

${ }^{258}$ OIOLI, Erik Frederico, op. cit., p. 169-170. 


\subsection{Projeto de oferta.}

Segundo o artigo 231-13 do RG da AMF, o projeto de oferta deve ser protocolado junto à AMF, através de carta a ela endereçada, a qual deve conter, dentre outras, as seguintes informações:

i) objetivos e a intenção do ofertante;

ii) número e a natureza das ações de emissão da companhia visada que o ofertante detém sozinho ou em conjunto ou pode deter, conforme sua iniciativa, bem como a data e as condições nas quais sua aquisição foi realizada ao longo dos 12 últimos meses ou pode ser realizada no futuro;

iii) preço e condições de pagamento.

No Brasil, de acordo com o artigo 258 da LSA, o instrumento da oferta, elaborado pelo ofertante e pela instituição financeira, deverá indicar, dentre outros, os seguintes elementos:

i) informações sobre o ofertante;

ii) preço e condições de pagamento;

iii) subordinação da oferta ao número mínimo de aceitantes e a forma de rateio entre os aceitantes, se o número deles ultrapassar o máximo estabelecido;

iv) procedimento a ser adotado pelos acionistas aceitantes, a fim de manifestarem sua aceitação, efetivando a transferência das ações.

Para Modesto Carvalhosa, o fundamento da exigência de informações consiste na proteção dos interesses dos acionistas da companhia visada e dos investidores do mercado em geral, sendo, pois, necessário que as informações possibilitem aos destinatários da oferta um julgamento consciente sobre a oportunidade e a conveniência de aceitarem ou 
não a oferta ${ }^{259}$. No entanto, diferentemente do que ocorre no direito francês, não se exige que o instrumento de oferta descreva os objetivos e a intenção do ofertante, o que é criticável, pois acionistas e administradores ficarão sem elementos importantes para a análise da oferta, conforme o caso.

Com relação ao preço, no direito francês, ele é, em princípio, estabelecido pelo ofertante, havendo certo controle por parte da AMF, conforme adiante analisado. Apesar disso, como aponta Alain Viandier, a escolha do preço é um dos problemas mais delicados com que o ofertante se depara:

\footnotetext{
"Le choix du prix d'offre est l'un des problèmes les plus délicats auquel est confronté l'initiateur; il lui faut proposer un prix attractif sans cependant payer une prime trop importante, qui pèsera sur le financement de l'opération et réduira les possibilités de surenchère ultérieure. Le prix dépend au surplus du rendement espéré de l'acquisition, des possibilités de vente de certains actifs de la cible, des synergies entre la société convoitée et l'initiateur, et de l'état du marché en matière de prime (...) $)^{, 260}$.
}

Durante muito tempo a autoridade reguladora do mercado francês desempenhou um papel importante no que se refere ao controle de preço. Assim, o CMF e, após, a AMF apreciavam a conformidade da oferta, examinando, por exemplo, o preço em função de critérios objetivos de avaliação, usualmente utilizados, e das características da companhia visada. Ocorre que a transposição da Diretiva n 2004/25/CE alterou esse panorama, haja vista inexistir, na referida Diretiva, qualquer exigência de preço mínimo, quando se tratar de oferta voluntária. Dessa forma, a AMF adaptou seu RG, limitando o controle do preço, apenas, por exemplo, nos casos de ofertas públicas obrigatórias e de retirada obrigatória ${ }^{261}$. Isso não significa, contudo, que todo controle tenha desaparecido. Assim o explica Alain Viandier:

\footnotetext{
“Ce serait une erreur de considérer que tout contrôle a disparu. D’abord, la déclaration de conformité s'apprécie au regard, notamment, des principes posés à
}

\footnotetext{
${ }^{259}$ CARVALHOSA, Modesto. Oferta pública de aquisição de ações. Rio de Janeiro: IBMEC, 1979, p. 190.

${ }^{260}$ VIANDIER, Alain, op. cit., p. 158. Tradução livre: “A escolha do preço é um dos problemas mais delicados enfrentados pelo ofertante. Ele deve propor um preço atraente sem, contudo, pagar um prêmio muito alto, que pesaria sobre o financiamento da operação e reduziria as possibilidades de posterior melhoria da oferta. O preço depende, ainda, do rendimento esperado da aquisição, das possibilidades de venda de certos ativos da companhia visada, das sinergias entre esta e o ofertante e do mercado em termos de prêmio". ${ }^{261}$ Idem, ibidem.
} 
l'article 231-3, dès lors que l'AMF 'peut demander à l'initiateur de modifier son projet d'offre si elle considère qu'il peut porter atteinte ... notamment aux principes définis par l'article 231-3' (RG, art. 231-18, 2, a),'262.

Com base no artigo 231-18, 20, "a", do RG da AMF, bem como no artigo 231-21 do RG da AMF, é que esta realiza o controle do preço. Primeiramente, conforme o artigo 231-18, 2 " "a", do RG da AMF, a nota de informação, deve conter a indicação do preço proposto "en fonction des critères d'évaluation objectifis usuellement retenus, des caractéristiques de la société visée et du marché de ses titres" ${ }^{263}$.

$\mathrm{O}$ artigo 231-21 do RG da AMF determina que a AMF pode solicitar que o ofertante modifique seu projeto de oferta, se considerá-lo contrário aos princípios definidos pelo artigo 231-3 do RG da AMF. Dessa forma, pode a AMF decidir pela não conformidade de um projeto, caso o preço tenha sido definido como demasiadamente contrário às forças do mercado, com base no princípio do "déroulement ordonné des offres publiques" ou no princípio da loyauté.

Existiu, como ensina Alain Viandier, uma evolução no que se refere à natureza do controle, que se concentra, em princípio, mais na informação relativa ao preço, ou seja, na sua coerência, na sua suficiência e menos no próprio preço. Ocorre que, na prática, é difícil

262 VIANDIER, Alain, op. cit., p. 158. Tradução livre: "Seria um erro considerar que todo controle desapareceu. Primeiro, a declaração de conformidade é realizada com base, notadamente, nos princípios constantes do artigo 231-3, já que a AMF 'pode requerer ao ofertante que modifique seu projeto de oferta, se considerar que mencionado projeto contraria ... sobretudo os princípios definidos pelo artigo 231-3' (RG, art. 231-18, 20, a)".

${ }^{263} \mathrm{O}$ disposto no artigo em questão é, de certo modo, contrário à liberdade de determinação do preço da OPA. Assim, afirma Thierry Bonneau: “On doit donc en déduire que l'initiateur est désormais libre de déterminer le prix comme il le souhaite, ce qui implique que le prix peut être déterminé autrement qu'en tenant compte d'une pluralité de critères. On peut toutefois se demander si cette liberté est aussi grande qu'il paraît parce que la méthode multicritère est prise en compte dans la réglementation de la note d'information de l'initiateur: le projet de note d'information doit en effet préciser, en ce qui concerne la teneur de l'offre, 'le prix ou la parité proposés, en fonction des critères d'évaluation objectifs usuellement retenus, des caractéristiques de la société visée et du marché de ses titres" (BONNEAU, Thierry; DRUMMOND, France, op. cit., p. 895). Tradução livre: “O ofertante é, pois, livre para determinar o preço como desejar, o que implica dizer que o preço pode ser determinado de modo diverso do que aquele que leva em conta uma pluralidade de critérios. Podemos, contudo, nos perguntar se tal liberdade é tão grande quanto parece, já que o método multicritérios faz parte da disciplina da nota de informação do ofertante: o projeto de nota de informação deve indicar, com relação ao conteúdo da oferta, 'o preço/troca propostos, em função de critérios de avaliação objetivos usualmente observados, das características da companhia visada e do mercado dos valores mobiliários". 
distinguir entre o controle existente hoje e aquele anterior à Lei $n^{\circ} 2006-387$, de 31 de março de $2006^{264}$.

No Brasil, não havia na lei societária a determinação de um critério de preço, aplicável à OPA para aquisição do controle, prevalecendo a autonomia da vontade das partes $^{265}$. Isso não significa que não existia controle do preço exercido pela CVM, que deveria, nas palavras de Erik Frederico Oioli, no caso de OPA de permuta, por exemplo, "analisar a qualidade, suficiência e consistência, entre outras, das informações relativas à formação do preço e fixação da relação de troca, a fim de que os acionistas destinatários da oferta possam tomar uma decisão consciente e independente acerca da permuta de ações"266.

A Instrução CVM no 487/10 modificou a Instrução CVM no 361/02 no que se refere ao preço. Isso porque foram acrescentados, por exemplo, dois importantes dispositivos acerca da determinação do preço pelo ofertante, quais sejam o $\$ 6^{\circ}$ do artigo 10 e o artigo 15-B. O primeiro dispõe que "caso o preço da OPA seja diferente do preço praticado nas negociações divulgadas nos termos do inciso $\mathrm{IV}^{267}$, o ofertante deverá justificar por que esse preço não foi adotado". Já, o segundo prevê que "o preço por ação da OPA não poderá ser inferior ao menor preço pago por ação pelo ofertante ou pessoas vinculadas em negócios realizados durante o período da OPA".

A modificação em questão é importante, pois, ao determinar critérios para a fixação do preço, trouxe maior transparência a esse procedimento, não deixando apenas a cargo da CVM o controle do preço. Considerando que, na França, o preço é, em princípio, livremente fixado pelo ofertante, como estudado, seria interessante que a legislação francesa adotasse dispositivos semelhantes ao da brasileira, de modo a evitar abusos e uma grande liberdade à $\mathrm{AMF}$ no que se refere ao controle de preços.

\footnotetext{
${ }^{264}$ VIANDIER, Alain, op. cit., p. 159.

${ }^{265}$ OIOLI, Erik Frederico. Oferta pública de aquisição do controle de companhias abertas. São Paulo, 2008. Dissertação (Mestrado em Direito). Faculdade de Direito, Universidade de São Paulo, p. 107.

${ }^{266}$ Idem, ibidem.

${ }^{267}$ Dispõe o artigo 10, IV, da Instrução CVM n 3 361/02: “O instrumento da OPA será firmado conjuntamente pelo ofertante e pela instituição intermediária e conterá, além dos requisitos descritos no Anexo II a esta Instrução, o seguinte: IV - declaração pelo ofertante, acerca do preço por ação da companhia objeto em negociações privadas relevantes, entre partes independentes, envolvendo o ofertante, o acionista controlador ou pessoas a ele vinculadas, realizadas nos últimos 12 (doze) meses".
} 


\subsection{Irrevogabilidade da oferta e seus temperamentos.}

As ofertas públicas de aquisição submetem-se a diversos princípios, tais como, o da igualdade entre os acionistas; o da transparência; o da boa fé; o da lealdade nas transações e competições. Decorre desses princípios aquele referente à irrevogabilidade das ofertas públicas, justificado por um imperativo de segurança jurídica, permitindo assegurar tanto a segurança do mercado como a da companhia visada e a dos seus $\operatorname{acionistas}^{268}$.

O princípio da irrevogabilidade da OPA remonta à disciplina sobre oferta pública estabelecida pela Companhia dos Corretores, no início dos anos 1970. Após, ele foi inserido no RG do $\mathrm{CBV}^{269}$, bem como na Diretiva $n^{\circ} 2004 / 25 / \mathrm{CE}^{270}$. O RG da AMF indica, como lembra Alain Viandier, de maneira indireta ${ }^{271}$, o caráter irrevogável da OPA, ao estabelecer, como já mencionado, no artigo 231-13, al. 2, que a oferta é realizada "par lettre addressée à l'AMF garantissant, sous la signature d'au moins un des établissements présentateurs, la teneur et le caractère irrrévocable des engagements pris par l'initiateur".

A oferta torna-se irrevogável a partir da decisão de conformidade proferida pela $\mathrm{AMF}^{272}$, em razão da natureza jurídica de tal decisão, que, nas palavras de Alain Viandier, “ $n$ 'est pas une condition suspensive affectant l'offre, mais une autorisation administrative indispensable à la validité de l'offre; en d'autres termes, il ne s'agit pas d'une modalité de l'offre, mais d'un élément legal de validité de celle ci" ${ }^{273}$. Em decorrência disso, a OPA não produz efeito antes da decisão de conformidade, podendo o ofertante retirar sua oferta antes do posicionamento da $\mathrm{AMF}^{274}$.

\footnotetext{
${ }^{268}$ CONAC, Pierre-Henri. L'offre publique d'acquisition conditionnelle. In: Droit bancaire et financier: mélanges AEDBF - France IV. Paris: Revue Banque Édition, 2004, p. 86.

${ }^{269}$ Artigos 5-2-1 e 5-2-5 do RG do CBV.

${ }^{270}$ Artigo 13 (e) da Diretiva n ${ }^{\circ}$ 2004/25/CE.

${ }^{271}$ VIANDIER, Alain, op. cit., p. 165.

${ }^{272}$ CONAC, Pierre-Henri, op. cit., p. 87 e VIANDIER, Alain, op. cit., p. 166. Existe, contudo, discussão a esse respeito. Para Laurent Faugérolas, por exemplo, o princípio da irrevogabilidade da oferta se aplica desde a apresentação do projeto de oferta perante a AMF (FAUGÉROLAS, Laurent; DUPONT-JUBIEN, André, op. cit., p. 497).

${ }^{273}$ VIANDIER, Alain, op. cit., p. 166. Tradução livre: "não é uma condição suspensiva afetando a oferta, mas uma autorização administrativa indispensável à validade da oferta; em outras palavras, não se trata de uma modalidade de oferta, mas de um elemento legal de sua validade".

${ }^{274}$ É preciso notar, contudo, que, dependendo de como isso é feito, pode o ofertante ser responsabilizado com relação às pessoas que sofreram um prejuízo. Assim, não pode o ofertante retirar sua oferta "à la légère", ou seja, descuidadamente (Idem, ibidem).
} 
Torna-se importante notar que a irrevogabilidade tem também como objetivo fixar o vínculo do proponente ao conteúdo de sua proposta ${ }^{275}$, tornando-se paradoxal falar em modificação dos termos da oferta. É, pois, em princípio, inoperante a retratação da oferta. Ensinam Planiol e Ripert sobre a teoria das ofertas em geral que:

\footnotetext{
"O ofertante é obrigado a manter sua oferta durante todo o prazo, de sorte que sua retratação, sobrevinda antes do termo fixado, será inoperante: a primeira vontade será considerada ainda subsistente, e a aceitação determinará a conclusão do contrato se feita dentro do prazo" ${ }^{276}$.
}

Diante disso, a oferta, além de irrevogável, deve ser irretratável, bem como, de modo geral, imutável, salvo nos casos previstos na legislação vigente.

O RG da AMF permite a modificação da oferta em duas hipóteses. A primeira delas é aquela ligada à melhoria da proposta pelo ofertante. Como dito anteriormente, o RG da AMF, em seu artigo 232-6, permite que o ofertante melhore os termos de sua oferta ou da última oferta concorrente, no prazo de cinco jous de négociation antes do encerramento da oferta.

Complementa o artigo 232-7 do RG da AMF que o preço oferecido pode ser aumentado pelo ofertante, desde que o aumento seja de, pelo menos, $2 \%$ e em até cinco jours de négociation antes do término da oferta. O RG da $\mathrm{AMF}$, diferentemente da legislação brasileira ${ }^{277}$, não limita essa faculdade do ofertante inicial, podendo, pois, aumentar o preço de sua oferta tantas vezes quantas julgar necessárias, havendo OPA

\footnotetext{
${ }^{275}$ OIOLI, Erik Frederico. Oferta pública de aquisição do controle de companhias abertas. São Paulo: Quartier Latin, 2010, p. 163.

${ }^{276}$ PLANIOL, Marcel; RIPERT, Georges. Traité élémentaire de droit civil. v. 2. 11. ed. Paris: LGDJ, 1937, p. 33 .

${ }^{277}$ No Brasil, o percentual exigido é de $5 \%$, conforme o artigo $261, \S 1^{\circ}$, da LSA. Vale notar que o $\$ 5^{\circ}$ do artigo 13 da referida Instrução dispõe que, uma vez lançada uma OPA concorrente, o ofertante inicial e o concorrente podem aumentar o preço de suas ofertas tantas vezes quantas julgarem conveniente e por quaisquer valores, devendo tal aumento ser informado publicamente, com o mesmo destaque da oferta. A respeito de tal disposição afirma Erik Frederico Oioli: “(...). Interessante notar que a norma da CVM não determina percentual mínimo para a melhora do preço da oferta. Nesse caso, não se aplicaria o disposto no artigo $261, \S 1^{\circ}$, da LSA, restrito às ofertas sem concorrência. Trata-se, em verdade, de norma nova regulamentadora da OPA concorrente, criada no âmbito da competência da CVM expressa no artigo 257, $\S 4^{\circ}$, da LSA. Assim, o preço da OPA concorrente, ao menos em tese, poderá ser melhorado em qualquer percentual" (OIOLI, Erik Frederico. Oferta pública de aquisição do controle de companhias abertas. São Paulo: Quartier Latin, 2010, p. 163).
} 
concorrente ou não. Esse dispositivo confere ao ofertante uma vantagem no que se refere à disputa com relação ao preço ofertado pelas ações de emissão da companhia.

No caso de OPA de permuta, a AMF verifica se a mudança oferecida pelo ofertante resultou em uma melhoria significativa das condições propostas aos acionistas, em consonância com o artigo 232-7, al. 2, do RG da AMF.

O direito brasileiro, no caso de OPA de compra, seguiu o direito francês, que, no início, previa, igualmente ao direito brasileiro, o necessário aumento de, pelo menos, 5\% do preço oferecido. Além disso, a LSA prevê outra hipótese de modificação da OPA: havendo OPA concorrente, pode o primeiro ofertante prorrogar o prazo de sua oferta, para que coincida com o prazo da oferta concorrente ${ }^{278}$. Nesse caso, é obrigatório o envio de cópia do aditamento ao edital à CVM, na data da sua publicação, conforme artigo $5^{\circ}, \S 5^{\circ}$, da Instrução CVM nº 361/02.

Vale lembrar, que a Instrução da CVM n 361/01, com as alterações introduzidas pela Instrução CVM no 487/10, no seu artigo $5^{\circ}$, I, permite, independentemente de autorização da CVM, a modificação da OPA por melhoria da oferta em favor dos destinatários, ou por renúncia, pelo ofertante, a condição por ele estabelecida para a efetivação da OPA. O que se verifica é uma simplificação no procedimento de modificação da oferta quando se tratar de casos que envolvam, por exemplo, a melhoria nas condições da oferta, já que não é mais necessária a autorização da CVM.

Quanto à OPA de permuta, o artigo $5^{\circ}, \S 2^{\circ}$, III, “a” da Instrução CVM n ${ }^{\circ}$ 361/02 determina ser possível a revogação ou modificação da OPA caso, a juízo da CVM, tenha existido alteração substancial, posterior e imprevisível, nas circunstâncias de fato existentes quando do lançamento da OPA, acarretando aumento relevante dos riscos assumidos pelo ofertante. Nota-se que a CVM possui poderes mais amplos para apreciar a melhoria nas condições da oferta, devendo o dispositivo em questão ser analisado, como afirma Erik Frederico Oioli, da seguinte maneira:

“Embora a CVM tenha poderes para expedir normas sobre OPA, não poderia extrapolar os limites impostos pela Lei das Sociedades Anônimas, admitindo a

${ }^{278}$ Artigo 262, $§ 2^{\circ}$, da LSA. 
livre revogação da OPA de permuta. Por outro lado, a CVM também tem poderes para regular as ofertas públicas de valores mobiliários, fundados na Lei $n^{\circ}$ 6.385/76. Assim, a modificação ou revogação da oferta justifica-se por também envolver a oferta pública de valores mobiliários, aqueles que serão permutados na OPA. Somente nas hipóteses em que a CVM admite a modificação ou revogação da oferta pública de valores mobiliários deveria a OPA ser modificável ou revogável, além das hipóteses de modificação da OPA de compra que já foram analisadas acima. Tal interpretação teria, dessa forma, o condão de harmonizar a aparente exação da CVM em seu poder regulamentar quando admite a revogação ou modificação da OPA de permuta em hipóteses diversas das previstas na LSA"279.

Dessa forma, o regulador francês, de modo geral, deu maior importância aos acionistas destinatários da oferta, buscando, sobretudo, aumentar o preço oferecido ${ }^{280}$. É preciso notar, entretanto, como lembra Erik Frederico Oioli, que "uma oferta concorrente com as mesmas condições da primeira poderia ser interessante, especialmente se o concorrente estiver mais alinhado aos interesses da companhia que o primeiro ofertante",281.

O regulador brasileiro, com a alteração trazida pela Instrução CVM n 487/10, parece ter se preocupado com outras condições além do preço da oferta, sempre dando importância aos destinatários da oferta. Isso é positivo, pois, como lembra Erik Frederico Oioli, o legislador conseguiria o mesmo objetivo, qual seja dar fôlego à sua proposta, considerando-se outros aspectos, como a retirada de certa condição para o negócio ${ }^{282}$.

\footnotetext{
${ }^{279}$ OIOLI, Erik Frederico. Oferta pública de aquisição do controle de companhias abertas. São Paulo: Quartier Latin, 2010, p. 166.

${ }^{280}$ Apesar da crítica em questão, vale notar que o direito francês admite a retirada de determinada condição para o negócio, qual seja a aceitação da oferta por um número mínimo de acionistas. Assim o explica Alain Viandier: "Une troisième question est celle de l'objet de la surenchère; on pense surtout à l'augmentation du prix, mais il peut s'agir également d'une suppression de la condition d'un nombre minimal de titres présentés en réponse pour que l'offre comporte une suite positive (art. 232-7), voire des deux à la fois (Sylis, AMF, déc. $n^{\circ}$ 208C1667, 12 septembre 2008)" (VIANDIER, Alain, op. cit., p. 299). Tradução livre: "Uma terceira questão se refere ao objeto da melhoria das condições da oferta pelo ofertante; pensamos, sobretudo, no aumento do preço ou na supressão da condição de um número mínimo de valores mobiliários que devem ser apresentados para que a oferta tenha um resultado positivo (art. 232-7) ou nos dois ao mesmo tempo (Sylis, AMF, déc. no 208C1667, 12 de setembro de 2008)".

${ }^{281}$ OIOLI, Erik Frederico. Oferta pública de aquisição do controle de companhias abertas. São Paulo: Quartier Latin, 2010, p. 148.

${ }^{282}$ Idem, p. 164.
} 
Apesar de não serem revogáveis, em princípio, as OPA, podem se sujeitar a determinadas condições, que poderão ser suspensivas ou resolutivas. O RG da AMF prevê algumas: necessidade de autorização prévia da assembleia geral de acionistas do ofertante, em razão de disposições legais, regulamentares ou estatutárias, desde que tal assembleia já tenha sido convocada no momento do protocolo do projeto de oferta junto à $\mathrm{AMF}^{283}$; obtenção das necessárias aprovações regulatórias; aceitação da oferta por um número mínimo de acionistas ${ }^{284}$. Com relação a essa última condição, não é possível admitir que o ofertante condicione sua oferta a 100\% das ações, já que, como explica Alain Viandier, a condição em questão seria irrealista e contrária à boa-fé, indo de encontro com a obrigação de lealdade imposta pelo artigo 231-3 do RG da $\mathrm{AMF}^{285}$.

A segunda hipótese é aquela ligada à OPA concorrente. No direito francês, o princípio da irrevogabilidade da oferta é "flexibilizado", sobretudo pelo disposto no artigo 232-11 do RG da AMF, que concede ao ofertante a possibilidade de renunciar à sua oferta, no prazo de cinco jours de négociaton, no caso de oferta concorrente, por exemplo.

\footnotetext{
283 Artigo 231-12 do RG da AMF.

${ }^{284}$ Artigo 231-11, al. 1, do RG da AMF.

${ }^{285}$ VIANDIER, Alain, op. cit., p. 155.
} 


\section{CAPÍTULO 4}

\section{TÉCNICAS DE DEFESA CONTRA OFERTA PÚBLICA PARA AQUISIÇÃO DO CONTROLE DE COMPANHIA ABERTA HOSTIL NA FRANÇA.}

Nos dizeres de Erik Frederico Oioli, é “impossível uma análise completa das OPA sem o estudo dos mecanismos de defesa que a companhia visada, por meio de seus administradores ou acionistas, pode utilizar para impedir o sucesso da oferta" ${ }^{286}$.

Na França, segundo Alain Viandier ${ }^{287}$, a situação jurídica atual é distinta daquela que prevalecia quando da realização das primeiras OPA, por diversos motivos, Inicialmente, o número de OPA aumentou, assim como sua diversidade, permitindo que autoridades e pessoas que se utilizam da operação em questão adquirissem experiência profunda no assunto ${ }^{288}$. Além disso, o “direito das ofertas públicas" atingiu um nível satisfatório de maturidade - observação essa que vale para o aspecto orgânico desse direito (ou seja, a repartição das competências e a cooperação entre as autoridades, assim como o papel desempenhado pelo juiz), bem como com relação a outros aspectos, tais como a afirmação de princípios gerais (v.g. igualdade na competição, interesse do mercado) e o fato de terem sido levados em consideração os interesses dos stakeholders (principalmente, dos assalariados) e não mais somente dos acionistas ou shareholders ${ }^{289}$.

Outra evolução se refere à globalização das economias europeias e à multiplicação das offres transfrontalières ${ }^{290}$, como demonstrado pela oferta pública lançada por Mittal Steel sobre Arcelor, em 2006 e por aquela lançada por Sacyr sobre

\footnotetext{
${ }^{286}$ OIOLI, Erik Frederico. Oferta pública de aquisição do controle de companhias abertas. São Paulo: Quartier Latin, 2010, p. 193.

${ }_{287}$ VIANDIER, Alain, op. cit., p. 49.

288 Idem, ibidem.

${ }^{289}$ Idem, ibidem.

${ }^{290}$ Thi Thanh Van VU traz alguns conceitos de offre publique transfrontière. Um deles é o conceito de J. E. Fisch, a seguir transcrito: mencionada oferta é definida como "une offre faite dans plus d'un pays ou celle dans laquelle l'initiateur, la société cible et les actionnaires de la société cible proviennent au moins de deux pays différents". Tradução livre: "uma oferta realizada em mais de um país ou aquela em que o ofertante, a companhia visada e os acionistas da companhia visada procedam de, ao menos, dois países diferentes". Já, M. Boucobza define a oferta pública em questão como "l'offre publique d'acquisition qui intéresse plusieurs marchés boursiers. Elle peut se caractériser par plusieurs facteurs d'extranéité. L'initiateur et la société cible peuvent être cotés sur des marchés différents (...)" Tradução livre: "a oferta pública de aquisição que interessa diversos mercados de capitais. Ela pode ser caracterizada por variados fatores de extraneidade. $\mathrm{O}$ ofertante e a companhia visada podem ter os valores mobiliários de sua emissão cotados em diferentes mercados (...)" (VU, Thi Thanh Van. Les offres publiques transfrontières. Paris, 2005. Tese [Doutorado em direito]. Université Paris II, p. 8).
} 
Eiffage $^{291}$, em 2007. A globalização em questão permitiu que fossem notadas as profundas diferenças entre as legislações dos Estados-Membros da UE, sobretudo no que se refere à proteção contra as OPA hostis e a liberdade de defesa dos administradores. Como exemplo, vale ressaltar que o princípio da neutralidade dos administradores, constante do artigo $9^{\circ}$ da Diretiva $n^{\circ} 2004 / 25 / C E$, não foi transposto por certos países, tais como Alemanha, Dinamarca, Luxemburgo, podendo as companhias visadas adotar medidas de defesa sem a necessidade de convocar assembleia geral de acionistas. Por outro lado, outros países como França, Itália, Espanha, Suécia e Reino Unido não concordaram em conferir tal liberdade aos administradores das companhias ${ }^{292}$.

É importante ressaltar que na França o debate a respeito da proteção das sociedades nacionais é intenso, tendo sido adotadas medidas quem visam à proteção de tais sociedades. Como exemplo, podem ser citados o Decreto $\mathrm{n}^{\circ} 2005-1739$, de 30 de dezembro de 2005, chamado de "Decreto anti-OPA", o qual precisou o procedimento de autorização prévia do Ministro da Economia, das Finanças e da Indústria para os investimentos estrangeiros em setores da atividade suscetíveis de interessar a ordem pública, a segurança pública ou a defesa nacional ${ }^{293}$, bem como a Lei $\mathrm{n}^{\mathrm{o}} 2005-842$, de 26 de julho de 2005, a chamada "loi Breton", a qual, segundo Nicolas Bombrun, prevê, em resumo, a obrigação para o ofertante de uma oferta pública lançada sobre uma companhia aberta cotada no mercado de capitais francês de lançar igualmente uma oferta sobre qualquer filial dessa sociedade cotada no estrangeiro ${ }^{294}$.

Tais fatores contribuíram para a evolução do direito francês no que se refere à matéria a ser examinada neste Capítulo. A princípio, serão estudadas as técnicas de defesa preventivas e, após, as técnicas de defesa adotadas durante a OPA ${ }^{295}$.

\footnotetext{
${ }^{291}$ Disponível em 〈http://www.amf-france.org/documents/general/8330_1.pdf>, p. 118 e 130. Acesso em: 25.05 .11 .

${ }^{292}$ VIANDIER, Alain, op. cit., p. 50.

${ }^{293}$ Nicolas Bombrun afirma, contudo, que é preciso relativizar o impacto do Decreto no $2005-1739$, de 30 de dezembro de 2005, pois não se refere unicamente às ofertas públicas de aquisição e traz, sobretudo, esclarecimentos no que tange ao procedimento de autorização administrativa (BOMBRUN, Nicolas; MOULIN, Frédéric. Défenses anti-OPA: le point après la loi "OPA" du 31 mars 2006. Revue trimestrielle de droit financier, Paris, n. 1, 2006, p. 19).

${ }^{294}$ Idem, ibidem.

295 João Pedro Barroso do Nascimento propõe uma catalogação das medidas defensivas com base em dois critérios - a saber: o momento em que são praticadas e a natureza jurídica dos instrumentos usados para a prática das medidas defensivas. Segundo o primeiro critério, as medidas podem ser preventivas (realizadas antes da OPA hostil) ou posteriores (realizadas após o início da OPA hostil). Essa distinção, para o mencionado autor, tem importância para se determinar eventual violação de deveres da administração e
} 
Considerando a amplitude do tema em questão, é necessária a imposição de limite na referida análise. Serão estudadas apenas algumas técnicas de defesa e seus principais aspectos.

\subsection{Técnicas de defesa preventivas.}

São inúmeras as medidas preventivas possíveis de serem adotadas, visando à proteção contra tentativas de tomada de controle hostil. Isso decorre da criatividade do empresariado, tornando difícil a análise de todas elas, além de não ser esse o escopo deste trabalho. Dessa forma, serão estudadas brevemente algumas medidas de defesa preventivas, mas, antes disso, serão analisados os princípios que as regem, conforme ensinado por Alain Viandier ${ }^{296}$.

\subsubsection{Princípios.}

Diferentes fatores, tais como o aumento do número de OPA, o desenvolvimento do direito das ofertas públicas, a globalização das economias europeias e a multiplicação das offres transfrontalières, contribuíram para a evolução da matéria ora analisada. Da evolução em questão decorreram cinco princípios a seguir indicados ${ }^{297}$.

\subsubsection{Legitimidade das defesas.}

A adoção de quaisquer medidas destinadas a prevenir o lançamento de uma OPA é lícita, não sendo tal medida proibida pelo C. com., tampouco pelo $\mathrm{RG}$ da $\mathrm{AMF}^{298}$. O que, na realidade, se restringe é a adoção de técnicas destinadas a evitar a OPA durante a sua realização, ou seja, posteriores ao seu início. Isso porque o artigo L. 233-32, I, do C. com. dispõe que, durante o período da oferta, o órgão de administração da companhia deve obter a aprovação prévia da assembleia geral de acionistas para a prática de quaisquer medidas que possam frustrar a OPA (princípio da neutralidade dos administradores).

responsabilização dos administradores, devido à adoção de medidas defensivas diante da OPA hostil. Conforme o segundo critério, as medidas podem ser classificadas em estatutárias, contratuais e institucionais. Foi utilizado, neste trabalho, o primeiro critério, pelo fato de a maioria da doutrina francesa utilizá-lo (v.g. Alain Viandier, Didier Martin, Nicolas Molfessis).

${ }^{296}$ VIANDIER, Alain, op. cit., p. 49-52.

${ }^{297}$ Idem, p. 50.

${ }^{298}$ Idem, p. 51. 
A jurisprudência, como lembra Alain Viandier ${ }^{299}$, decide no mesmo sentido. E, também, a CA de Paris, em decisão proferida quando da mudança de controle ocorrida no Groupe André, conforme trecho abaixo transcrito, não proibiu os dirigentes de uma companhia de combater a ação conjunta de alguns administradores para mudar a política da empresa, desde que o fizessem através de meios lícitos e ditados pela preocupação de defender o interessa da sociedade:

\begin{abstract}
“il n'est pas (...) interdit aux dirigeants d'une société de tenter de combattre l'action engagée par certains associés pour apparemment, modifier la politique de l'entreprise, dès lors qu'ils le font par des moyes licites et dictés par le souci de défendre l'intérêt de la société" ${ }^{300}$.
\end{abstract}

\title{
4.1.1.2 Transparência das defesas.
}

É primordial que os acionistas saibam da existência das defesas preventivas adotadas. Isso pode, por exemplo, ocorrer por meio das assembleias gerais extraordinárias ou por meio do relatório anual, que elenca os elementos suscetíveis de influenciar a OPA (artigo L. 225-100-3 do C. com) ${ }^{301}$.

\subsubsection{Proibição das proteções absolutas.}

A proibição das proteções absolutas significa que não pode ser adotada técnica de defesa que impeça o sucesso de toda e qualquer $\mathrm{OPA}^{302}$. Trata-se, segundo Alain Viandier, de um princípio geral do droit boursier ${ }^{303}$.

O artigo L. 233-34 do C. com. dispõe que, exceto quando resultarem de obrigação legal, as cláusulas do estatuto social de uma companhia aberta que prevejam restrições à transferência de ações são inoponíveis ao ofertante no âmbito da sua oferta ${ }^{304}$.

\footnotetext{
${ }^{299}$ VIANDIER, Alain, op. cit., p. 51.

${ }^{300}$ CA Paris, 15.03.00, JCP E 2000, p. 1016, note A. Viandier. Tradução livre: "os administradores de uma sociedade não estão proibidos de tentar combater a ação de certos sócios visando à modificação da política da empresa, desde que eles o façam por meios lícitos e ditados pela preocupação de defender o interesse social". 301 VIANDIER, Alain, op. cit., p. 51.

302 Idem, ibidem.

${ }^{303}$ Idem, ibidem.

${ }^{304}$ Alain Viandier questiona, por exemplo, a validade de uma das cláusulas inseridas no estatuto social da GVT, revelada, quando do lançamento da OPA pela Vivendi, cláusula essa que exigia que a oferta fosse, no mínimo, $25 \%$ da maior cotação atingida pelo papel no mercado nos últimos 12 meses. Alain Viandier critica
} 


\subsubsection{Conformidade das defesas preventivas ao interesse social ${ }^{305}$.}

Permanentemente, ao longo da existência da companhia, é preciso que se respeite o interesse social e não seria diferente durante o emprego de técnicas de defesa preventivas.

Como elucida Alain Viandier, as defesas preventivas contrárias ao interesse social podem levar à responsabilização civil e mesmo penal (abuso de poder ${ }^{306}$ ) de seus autores $^{307}$. Ademais, a anulação de tais defesas é possível, se forem preenchidos os requisitos necessários para a configuração do abuso de maioria ${ }^{308}$.

\subsubsection{Lealdade na competição.}

O princípio em questão é expresso, por exemplo, no RG da AMF, no artigo 231-3, que dispõe que todas as pessoas abrangidas pela OPA devem respeitar, dentre outros, o princípio da lealdade nas transações e na competição. Não é possível a existência de uma técnica que, ao conferir ao ofertante uma vantagem, determine previamente o sucesso da $\mathrm{OPA}^{309}$.

essa cláusula e questiona sua validade perante o direito francês. Para ele, tal cláusula não seria válida, pois o estatuto social não pode interferir no diálogo existente entre comprador e vendedor. Cabe a este apreciar se o preço lhe convém ou não e tal prerrogativa constitui um direito próprio, assim como o é o direito de ceder suas ações (Idem, p. 51-52).

${ }^{305}$ Embora não seja o escopo deste estudo, é preciso definir, mesmo que sucintamente, interesse social. Erasmo Valladão Novaes França, depois de ampla análise sobre o tema, identifica o interesse social stricto sensu e o interesse social lato sensu, sendo o primeiro assim definido: "Pode-se concluir, assim, que o interesse da companhia (ou interesse social strictu sensu), na Lei 6.404/76, constitui um conceito típico e específico, consistente no interesse comum dos sócios à realização do escopo social, abrangendo, portanto, qualquer interesse que diga respeito à causa do contrato de sociedade, seja o interesse à melhor eficiência da empresa, seja à maximização dos lucros, seja à maximização dos dividendos" (NOVAES FRANÇA, Erasmo Valladão. Conflito de interesses nas Assembléias de S.A. São Paulo: Malheiros, 1993, p. 62).

${ }^{306}$ Artigo L. 242-6, $4^{\circ}$, do C. com.

${ }^{307}$ VIANDIER, Alain, op. cit., p. 52.

${ }^{308}$ Segundo Dominique Schmidt, há 40 anos, a C. cass. considera que o abuso de maioria é configurado, quando uma decisão é tomada contrariando o interesse geral da sociedade e cujo único objetivo seja favorecer os membros da maioria em detrimento da minoria. Considerando que tais requisitos são cumulativos, a maioria pode, então, se beneficiar em detrimento da minoria, desde que sua decisão não seja contrária aos interesses da sociedade (SCHMIDT, Dominique. Les droits de minoritaires et les offres publiques. Recueil Dalloz, Paris, n. 27, 2007, p. 1892).

${ }^{309}$ VIANDIER, Alain, op. cit., p. 52. 


\subsubsection{Espécies.}

\subsubsection{Limitação ao número de votos.}

O direito de voto é um dos direitos mais importantes do acionista e, nas palavras de Philippe Merle, "est proportionnel à la quotité de capital représentée et chaque action donne droit à une voix au moins" ${ }^{310}$, nas deliberações da assembleia geral de acionistas ${ }^{311}$.

Desde a Ordonnance n ${ }^{\circ}$ 2004-604, de 24 de junho de 2004, a respeito da reforma dos valores mobiliários, e do Decreto de aplicação $\mathrm{n}^{\mathrm{o}}$ 2005-112, de 10 de fevereiro de 2005, é possível suspender o direito de voto das ações preferenciais ou mesmo suprimi-lo. Ademais, permite-se a limitação do número de votos de cada acionista nas deliberações assembleares pelo estatuto social. Desse modo, o artigo L. 225-125, al. 1, do C. com. prevê que os estatutos sociais podem estabelecer o número de votos máximo a ser exercido por cada acionista nas deliberações das assembleias gerais, desde que mencionada limitação seja imposta a todas as ações ${ }^{312}$ sem distinção de categoria.

Decorrem do mencionado dispositivo duas modalidades de limitação elaboradas pela prática, quais sejam a cláusula de limitação, propriamente dita, e a cláusula de ajuste. A cláusula de limitação impõe um limite ao número de votos suscetível de ser exercido por cada acionista, quando da realização das assembleias gerais. Exemplo disso é o artigo 14 do estatuto social da Société Générale, a seguir transcrito ${ }^{313}$ :

\footnotetext{
"Le nombre de voix dont peut disposer un actionnaire dans les Assemblées générales, qu'il vote personnellement ou par l'intermédiaire d'un mandataire, ne peut excéder $15 \%$ du nombre total des droits de vote existant à la date de la réunion $(\ldots)$ ".
}

\footnotetext{
${ }^{310}$ MERLE, Philippe. Droit commercial: sociétés commerciales. 14. ed. Paris: Dalloz, 2010, p. 371. Tradução livre: "é proporcional ao capital social representado e cada ação dá direito a um voto, pelo menos". ${ }^{311}$ Artigo L. 225-122, al. 1, do C. com.

${ }^{312}$ Excetuadas as ações preferenciais sem direito de voto.

${ }^{313}$ VIANDIER, Alain, op. cit., p. 75. Tradução livre: "O número de voto que cada acionista pode ter nas Assembleias gerais, votando ele pessoalmente ou por meio de um mandatário, não pode exceder $15 \%$ do número total dos direitos de voto existente na data da reunião".
} 
O estatuto da Société Générale ${ }^{314}$ prevê, ainda, que a limitação em questão não produzirá efeitos se, em decorrência de uma oferta pública, um acionista alcançar determinado percentual do capital social ou dos direitos de voto ${ }^{315}$.

No que se refere à cláusula de ajuste, a ideia é variar o limite em razão da taxa de abstenção nas assembleias gerais, evitando, nas palavras de Alain Viandier, um "excesso" de representação de um acionista, causado pela baixa participação dos demais à assembleia $^{316}$.

Independentemente da modalidade, dispõe o artigo L. 225-125, al. 2, do C. com. que os efeitos da limitação do número de votos (na hipótese de oferta pública de aquisição) serão suspensos, quando da realização da primeira assembleia geral após o encerramento da referida oferta, quando o ofertante obtiver mais de $2 / 3$ do capital ou dos direitos de voto $^{317}$.

Apesar de ser uma medida de defesa simples e eficaz, que evita, em princípio, a tomada de controle, os acionistas são hostis com relação à sua adoção. Eis o que explica Alain Viandier:

\begin{abstract}
"Il reste que les actionnaires y sont souvent hostiles, estimant à tort que de telles clauses sont de nature à rendre plus difficile une offre, alors que leur mérite n'est pas d'empêcher une offre, mais d'éviter une braderie du contrôle de la société, ou, pire, une prise de contrôle sans offre publique. Cette hostilité a pris une forme agressive en 2007, avec le dépôt systématique de résolutions visant à supprimer les clauses statutaires de limitation des droits de vote (...),318.
\end{abstract}

\footnotetext{
${ }^{314}$ Dispõe, ainda, o artigo 14 do estatuto da Société Générale que mencionado limite não é mais aplicável quando um acionista passa a deter, após a realização de oferta pública, diretamente, indiretamente ou em conjunto com outro acionista, mais de $50,01 \%$ dos direitos de voto.

315 A respeito da inserção da mencionada previsão nos estatutos sociais, afirma Alain Viandier que hoje é comum que os estatutos sociais contenham uma cláusula segundo a qual a limitação não possui mais efeito caso, após uma oferta pública, um acionista atinja determinado limite do capital ou dos direitos de voto. Lembra, ainda, o autor que referido dispositivo encontra-se presente nos estatutos sociais da Schneider e da Total (VIANDIER, Alain, op. cit., p. 75-76).

316 Idem, p. 76.

317 Artigo 231-54 do RG da AMF. Complementa o artigo 231-55 do RG da AMF que o estatuto social pode prever um limite inferior, mas os efeitos de tais restrições ligadas ao direito de voto serão suspensos na primeira assembleia geral após o encerramento da oferta, quando o ofertante passa a deter mais da metade do capital ou dos direitos de voto da companhia visada.

${ }^{318}$ VIANDIER, Alain, op. cit., p. 77-78. Tradução livre: “Os acionistas são geralmente hostis, já que estimam erroneamente que a adoção de tais cláusulas tornará a realização de uma oferta mais difícil. Na realidade, o mérito de tais cláusulas não é o de evitar uma oferta e sim o de evitar uma 'liquidação' (ou oferta) do
} 
No Brasil, o artigo $110, \S 1^{\circ}$, da LSA dispõe que o estatuto pode determinar a limitação ao número de votos de cada acionista, não existindo, contudo, previsão com relação à suspensão dos efeitos da limitação, no caso de oferta pública, e devendo o estatuto social especificar as características da limitação do número de votos, caso a caso.

Por fim doutrina José Luiz Bulhões Pedreira, conforme abaixo indicado, que a medida defensiva ora analisada, prevista no estatuto, se encontra em consonância com a legislação brasileira:

\footnotetext{
"É compatível com a lei brasileira em vigor o dispositivo estatutário que estabelece limite para os votos emitidos por cada acionista - em nome próprio e como representante de outro ou outros - mas se o estatuto social não é expresso, o limite aplica-se aos votos de cada acionista, considerado separadamente, sejam os votos exercidos pelo próprio acionista ou por mandatário"319.
}

\subsubsection{Notificação e declaração de intenção.}

No direito francês, as companhias abertas (com sede na França ${ }^{320}$ ), por meio de dispositifs d'alerte ${ }^{321}$, têm conhecimento de que determinado limite do capital social ou dos direitos de voto foi atingido, bem como da eventual declaração de intenção daquele que atingiu o referido patamar. Trata-se de um mecanismo importante, pois, além de impedir, em alguns casos, conforme acima mencionado, a tomada de controle por meio da escalada acionária, possibilita à companhia conhecer o investidor e a razão do seu investimento, para, se for o caso, adotar outras medidas de defesa preventivas.

A companhia terá conhecimento de que determinado limite do capital social ou dos direitos de voto foi atingido por meio de notificação, que deve ser enviada, no prazo fixado pelo artigo R. 233-1 do C. com., quando, por exemplo, forem atingidos os seguintes

controle da sociedade ou, ainda pior, uma tomada de controle sem oferta pública. Essa hostilidade se tornou agressiva, em 2007, com o protocolo sistemático de resoluções visando à supressão das cláusulas estatutárias de limitação dos direitos de voto (...)"

${ }^{319}$ LAMY FILHO, Alfredo; BULHÕES PEDREIRA, José Luiz. A Lei das S.A.. t. III (Pareceres). v. 2. 2. ed. Rio de Janeiro: Renovar, 1996, p. 77.

${ }^{320}$ Artigo 233-7, I, do C. com.

${ }^{321}$ Doutrina Alain Viandier que os dispositifs d'alerte disponíveis são: "la surveillance de marché (...), la notification des franchissements de seuils (...) et l'identification des actionnaires (...)" (VIANDIER, Alain, op. cit., p. 53). Tradução livre: "fiscalização do mercado (...), notificação, quando forem atingidos os limites estabelecidos (...) e identificação dos acionistas (...)". 
percentuais do capital social ou dos direitos de voto: 5\%, 10\%, 15\%, 20\%, 25\%, 33,33\%, 50\%, 66,66\%, 90\%, 95\% (artigo L. 233-7, I, do C. com.).

Vale ressaltar que o dispositivo ora analisado ${ }^{322}$ autoriza, ainda, que o estatuto social preveja obrigação de informação, quando forem atingidos percentuais inferiores àqueles anteriormente indicados, não podendo referido percentual ser inferior a $0,5 \%$ do capital social ou dos direitos de voto.

Além da notificação, como já citado, é preciso que o acionista indique à companhia e à AMF suas intenções com relação aos seis meses seguintes no que se refere à aquisição de ações, tomada de controle ${ }^{323}$, por exemplo, quando forem ultrapassados determinados limites, quais sejam 10\%, 15\%, 20\%, 25\% do capital social ou dos direitos de $\operatorname{voto}^{324}$.

\subsection{Técnicas de defesa adotadas durante a oferta pública para aquisição do controle de companhia aberta ${ }^{325}$.}

Afirma Alain Viandier que, durante muito tempo, o centro das atenções em matéria de técnicas de defesa foram as defesas preventivas, principalmente porque, após o início da oferta, a companhia visada possui uma liberdade reduzida, sendo limitado o seu campo de ação ${ }^{326}$.

Na França, a grande maioria das OPA hostis terminou com a vitória do ofertante, principalmente em razão da melhoria das condições da oferta. Diante disso, afirma Alain Viandier que "au final, toute offre hostile ou presque a vocation à devenir (...) amicale, après une amélioration du prix ${ }^{\text {} 327 . ~}$

\footnotetext{
${ }^{322}$ Artigo L. 233-7, III, do C. com.

${ }^{323}$ VIANDIER, Alain, op. cit., p. 63.

${ }^{324}$ Artigo L. 233-7, VII, do C. com.

${ }^{325}$ São técnicas de defesa adotadas durante o período da oferta, conforme acima estudado.

${ }^{326}$ VIANDIER, Alain, op. cit., p. 326.

${ }^{327}$ Idem, ibidem. Tradução livre: "no final, toda oferta hostil possui vocação a se tornar (...) amigável, depois do aumento no preço".
} 
A reforma de $2006^{328}$ adotou o disposto no artigo $9^{\circ}$ da Diretiva ${ }^{\circ}$ 2004/25/CE, acolhendo, portanto, o princípio da neutralidade dos administradores. No entanto, essa regra pode, com base no princípio da reciprocidade, ser excepcionada ${ }^{329}$. Nesse caso, é conferido um importante papel aos acionistas da companhia.

Para a melhor compreensão do espírito da Lei no 2006-396, de 31 de março de 2006, serão analisadas algumas regras de competência aplicáveis às técnicas de defesa adotadas durante a oferta. Após isso, serão analisados os princípios relativos às defesas durante a oferta e, finalmente, serão estudadas algumas técnicas de defesa passíveis de serem adotadas durante a realização da oferta pública.

\subsubsection{Regras de competência.}

No que se refere à competência do diretor geral ${ }^{330}$, dispõe o artigo L. 225-56, I, do C. com. que possui os mais amplos poderes para agir em qualquer circunstância, em nome da sociedade, além de representá-la perante terceiros ${ }^{331}$. Nesse sentido, além de cuidar do andamento da companhia, cabe ao diretor geral (ou ao directoire, dependendo do caso), nas palavras de Alain Viandier, "mettre la société en ordre de bataille"332, ou seja, escolher

\footnotetext{
${ }^{328}$ Com a transposição da Diretiva no 2004/25/CE pela Lei no 2006-387, de 31 de março de 2006.

${ }^{329} \mathrm{Na}$ hipótese de estar o ofertante sediado em país que admita a livre adoção de técnicas de defesa pelo órgão de administração da companhia, a companhia francesa visada poderá também adotar medidas de defesa livremente (OIOLI, Erik Frederico. Oferta pública de aquisição do controle de companhias abertas. São Paulo: Quartier Latin, 2010, p. 128).

${ }^{330}$ Vale notar que, após a Lei no 2001-420, de 15 de maio de 2001 (“loi NRE”), o diretor geral, cuja nomeação é obrigatória, tornou-se o personagem central na sociedade anônima com administração "do tipo clássica" (com conselho de administração e presidente).

${ }^{331}$ Para Philippe Merle, uma das principais inovações da Lei no 66-537, de 24 de julho de 1966, foi oferecer a possibilidade de escolha entre a administração "do tipo clássica", com conselho de administração e presidente e uma nova fórmula, inspirada no direito alemão, com directoire e conseil de surveillance ("sociedade dual"). Vale notar que, após a Lei no 2001-420, de 15 de maio de 2001 ("loi NRE"), o diretor geral, cuja nomeação é obrigatória, tornou-se o personagem central na sociedade anônima com administração do tipo clássica. Em resumo, na "sociedade dual", ao directoire incumbe a gestão corrente da empresa, possuindo certa autonomia com relação ao conseil de surveillance. A este cabe, essencialmente, exercer o controle permanente da gestão da sociedade feita pelo directoire (MERLE, Philippe. Droit commercial: sociétés commerciales. 14. ed. Paris: Dalloz, 2010, p. 424, 520, 536 e 550). Como lembra Philippe Merle, possui o directoire algumas funções específicas enumeradas pela Lei, tais como, convocação da assembleia geral e fixação da ordem do dia (art. L. 225-103 do C. com e art. L. 225-105 do C. com.); aumento ou redução do capital social, desde que exista delegação da assembleia geral extraordinária nesse sentido (art. L. 225-129-1 do C. com. e art. L. 225-204 do C. com.) (Idem, p. 543). Cabe, sobretudo, ao directoire uma atribuição mais ampla, haja vista que, assim como o diretor geral (na sociedade com administração do tipo clássica), é investido dos mais amplos poderes para agir em quaisquer circunstâncias, em nome da sociedade (artigo 225-64, al. 1, do C. com.).

${ }^{332}$ VIANDIER, Alain, op. cit., p. 328. Tradução livre: “colocar a empresa em ordem de batalha".
} 
a instituição financeira, advogados, assim como tomar as medidas necessárias para preservar o interesse da companhia ${ }^{333}$.

Quanto ao conselho de administração e ao conseil de surveillance, seus poderes, no geral, permanecem os mesmos durante a $\mathrm{OPA}^{334}$, devendo ser respeitada a regra, adiante examinada, no sentido de que devem ser submetidas à assembleia geral quaisquer medidas passíveis de frustrar a OPA.

Decorre do período da oferta o surgimento de outros poderes/deveres próprios dos conselhos. É o caso, por exemplo, do parecer motivado sobre a oferta, previsto no artigo 231-19, $4^{\circ}$, do RG da AMF, parecer esse que deve se referir ao interesse da oferta e às suas consequências para a companhia visada, seus acionistas e trabalhadores ${ }^{335}$. Na prática, mencionado parecer representa um limite ao princípio da neutralidade dos administradores, já que pode influenciar os acionistas da companhia visada a, por exemplo, não participarem da oferta, contribuindo parao seu insucesso ${ }^{336}$.

Com relação à competência da assembleia geral de acionistas, é preciso lembrar que cabe aos acionistas decidir sobre o mérito da oferta e, nas palavras de Alain Viandier, "les dirigeants de la société cible ne sauraient, par leurs propres décisions, les priver du bénéfice de l'offre" 337 .

A Lei n ${ }^{\circ}$ 2006-396, de 31 de março de 2006 expressamente adotou o princípio da neutralidade dos administradores, ao exigir, no artigo L. 233-32 do C. com., que o órgão de administração da companhia visada obtenha autorização prévia da assembleia geral de acionistas, para a adoção de medidas que seriam geralmente de sua competência, mas que, por serem susceptíveis de frustrar a OPA, passaram a ser de competência temporária ${ }^{338}$ da assembleia geral de acionistas ${ }^{339}$.

\footnotetext{
${ }^{333}$ Por exemplo, afirma Alain Viandier (Idem, p. 329), que incumbe ao diretor geral "la saisine de l'AMF s'il estime que l'offrant ne respecte pas les règles du jeu en matière d'information, par exemple, en jetant le discrédit sur la cible". Tradução livre: "recorrer à AMF, se ele entende que o ofertante não respeita as regras do jogo em matéria de informação, por exemplo, ao tomar atitudes que não favoreçam a companhia visada".

${ }_{334}^{334}$ VIANDIER, Alain, op. cit., p. 329.

335 Idem, p. 330.

336 Idem, ibidem.

${ }^{337}$ Idem, p. 331. Tradução livre: "os dirigentes da companhia visada não podem, por suas próprias decisões, privá-los do benefício da oferta".

${ }_{338}$ Pode-se extrair lição nesse sentido de Frédéric Grillier: "Dans le contexte de la nouvelle réglementation, toutes les mesures prises par une société, à chaud, c'est-à-dire en période d'offre, doivent respecter le
} 
Para Alain Viandier, a medida suscetível de frustrar a OPA é aquela que, em razão das circunstâncias, impede a tomada de controle pelo ofertante, por exemplo. Assim o explica o autor em questão:

\begin{abstract}
"Ainsi pourrait-on considérer qu'une mesure est susceptible en fonction des circonstances de faire échec à l'offre si elle empêche la prise de contrôle par l'offrant, ou si elle affecte de manière significative la consistance de la cible, ou encore si elle prive l'offre de tout objet. Au fond, cela revient à dire que l'assemblée générale doit approuver préalablement la mesure qui, si elle avait pu être pressentie par l'offrant, aurait dissuadé ce dernier de lancer son offre" ${ }^{340}$.
\end{abstract}

principe fondamental de la primauté des actionnaires. Principe qui exige que toutes les mesures susceptibles de faire échouer l'offre fassent l'objet selon le cas soit d'une autorisation soit d'une confirmation par l'assemblée générale des actionnaires. Ce principe de primauté des actionnaires a pour corollaire le dessaisissement du conseil d'administration, qui voit sa sphère de compétence limitée à la seule gestion du cours normal des affaires, c'est-à-dire à toute mesure qui n'est pas susceptible de faire échouer l'offre publique" (GRILLIER, Frédéric. Nouveau cadre législatif concernant les mesures de défense anti-OPA. Enjeux et incertitudes. Inventaire des principales mesures \& nouveautés. Revue trimestrielle de droit financier, Paris, n. 3, 2006, p. 101). Tradução livre: "No contexto da nova regulamentação, todas as medidas tomadas por uma sociedade, durante o período da oferta, devem respeitar o princípio fundamental da primazia dos acionistas, que exige que todas as medidas suscetíveis de frustrar a oferta sejam, conforme o caso, autorizadas ou confirmadas pela assembleia geral de acionistas. O princípio em questão tem como corolário a limitada competência do conselho de administração, ou seja, o fato de sua competência se limitar à administração do curso normal dos negócios, sendo competente com relação às medidas não suscetíveis de frustrar a oferta".

${ }^{339}$ Segundo Alain Viandier, "cela concerne: les mesures projetées, les mesures déjà prises et non encore mises en œuvre et les délégations accordées avant la période d'offre ; il faut ajouter les décisions relevant de la compétence de droit commun de l'assemblée générale" (VIANDIER, Alain, op. cit., p. 331). Tradução livre: "isso diz respeito: às medidas propostas, às medidas tomadas e não implementadas e às delegações acordadas antes do período da oferta. É preciso lembrar das decisões de direito comum da assembleia geral". No mesmo sentido, afirma Didier Martin que "le principe de neutralité des organes de direction et d'administration de la société cible implique en premier lieu que toute mesure prise pendant la période d'offre dont la mise en ouvre est susceptible de faire échouer l'offre fasse l'objet d'une approbation préalable de l'assemblée générale des actionnaires. Il implique également la confirmation par l'assemblée générale des décisions prises avant la période d'offre qui n'ont pas encore été exécutées. Enfin, il emporte la suspension des délégations qui ont été consenties par l'assemblée générale aux organes de direction et d'administration avant la période d'offre" (MARTIN, Didier; MOLFESSIS, Nicolas. Offres publiques. Les mesures de défense anti-OPA. In: CANIVET, Guy; MARTIN, Didier; MOLFESSIS, Nicolas (Org.). Les offres publiques d'achat. Paris: Litec, 2009, p. 585). Tradução livre: "o princípio da neutralidade dos órgãos de direção e de administração da companhia visada significa, em primeiro lugar, que toda medida tomada durante o período da oferta, que seja suscetível de frustrar mencionada oferta, deve ser previamente aprovada pela assembleia geral de acionistas. Ele requer, igualmente, a confirmação pela assembleia geral das decisões tomadas antes do período de oferta e que ainda não foram implementadas. Enfim, ele acarreta a supressão das delegaçães pela assembleia geral aos órgãos de direção e de administração antes do período da oferta".

${ }^{340}$ Idem, p. 334. Tradução livre: "Pode-se considerar que uma medida é suscetível, em função das circunstâncias, de frustrar a oferta, se ela impede a tomada de controle pelo ofertante ou se ela afeta de modo significativo a consistência da companhia visada ou, ainda, se ela priva a oferta de qualquer objeto. No fundo, isso significa dizer que a assembleia geral deve previamente aprovar a medida que, se pudesse ter sido prevista pelo ofertante, o teria dissuadido de lançar sua oferta". 


\title{
4.2.2 Princípios aplicáveis.
}

O princípio geral aplicável às medidas em questão é o direito de se defender ${ }^{341}$. De acordo com esse princípio, toda companhia, durante e mesmo antes da realização da OPA, tem o direito de se defender ${ }^{342}$. Alain Viandier aprofunda a questão, ao afirmar que existiria mesmo um dever de resistência, ou seja, a companhia e seus dirigentes, considerando o interesse social, deveriam se defender, mesmo que seja apenas para provocar uma melhoria nas condições financeiras da oferta. Eis o que afirma o autor:

\begin{abstract}
“On peut même se demander si la société et donc ses dirigeants n'ont pas un devoir de résistance à l'encontre des offres non sollicitées, ne serait-ce que pour tenter de provoquer une amélioration des conditions financières de l'offre (...) et un renforcement des divers engagements pris par l'offrant, par exemple en matière sociale. Ni la règlementation, ni la jurisprudence n'ont affirmé, en France, un tel devoir, mais il nous paraît compris dans le nécessaire respect de l'intérêt social" ${ }^{\text {"343. }}$.
\end{abstract}

Não é possível afirmar, previamente, que a melhoria das condições financeiras sempre irá ao encontro do interesse social, devendo tal análise ser feita caso a caso.

O direito de se defender encontra alguns limites, ou seja, não deve ser exercido de qualquer maneira. O primeiro limite é o interesse social. Assim, é preciso que as decisões relacionadas ao direito em questão estejam em consonância com o interesse social. Em outras palavras, os administradores e o acionista controlador não podem se utilizar das defesas para a promoção dos próprios interesses ${ }^{344}$. Outro limite se refere ao fato de ser a liberdade de defesa enquadrada, de certa forma, pelas normas do RG da $\mathrm{AMF}^{345}$, principalmente, pelo já mencionado artigo 231-3, o qual prevê algumas regras, tais como: andamento ordenado das operações; respeito do livre jogo das ofertas; igualdade de

\footnotetext{
${ }^{341}$ VIANDIER, Alain, op. cit., p. 326.

${ }^{342}$ Idem.

${ }^{343}$ Idem, p. 327. Tradução livre: "podemos até nos perguntar se a sociedade e, pois, seus administradores não possuem um dever de resistência com relação às ofertas não solicitadas, mesmo que seja para tentar uma melhoria nas condições financeiras da oferta (...) - e um aumento dos compromissos assumidos pelo ofertante, por exemplo, em questões sociais. Tal dever não foi imposto pela jurisprudência, tampouco pela legislação, na França, mas parece estar inserido no necessário respeito ao interesse social".

${ }^{344}$ OIOLI, Erik Frederico. Oferta pública de aquisição do controle de companhias abertas. São Paulo: Quartier Latin, 2010, p. 212.

${ }^{345}$ VIANDIER, Alain, op. cit., p. 327.
} 
tratamento e de informação dos detentores das ações envolvidas na operação; transparência e integridade do mercado e lealdade nas transações ${ }^{346}$.

\subsubsection{Espécies.}

\subsubsection{Cavaleiro branco ${ }^{347}$ (chevalier blanc).}

O cavaleiro branco é a medida defensiva adotada durante a realização da OPA hostil. Os administradores, por entenderem que a tentativa de tomada de controle contraria os interesses da companhia visada, procuram um ofertante, para lançar uma oferta concorrente.

O mecanismo em questão não se submete ao princípio da neutralidade dos administradores, pois o próprio artigo L. 233-32, I, do C. com. excepciona a procura de ofertas concorrentes $^{348}$. Apesar disso, não podem os administradores conceder ao cavaleiro branco, de acordo com uma decisão da CA de Paris, datada de 27 de abril de 1993, "un avantage déterminant par avance le succès de son offre publique en faussant le jeu des offres et des surenchères" ${ }^{\text {349 }}$. Para Alain Viandier, não se trata de uma medida de defesa, pois, de qualquer maneira, a companhia visada terá seu controle adquirido, não conservando sua independência. Ocorre que, nas palavras do citado autor, "l'habitude a été prise d'y voir une forme de défense, sinon pour la société, au moins pour ses dirigeants, 350 .

Tal medida defensiva pode ocorrer no Brasil, haja vista a previsão da oferta pública concorrente pelo artigo 262 da LSA e sua minuciosa disciplina pela Instrução CVM no 361/02. Além disso, desde que a medida vá ao encontro do interesse da

\footnotetext{
${ }^{346}$ A AMF aplicou o artigo em questão, quando da OPA lançada por Sanofi-Synthélabo sobre Aventis, ao decidir a respeito de um projeto de emissão de bônus de subscrição da Aventis.

${ }^{347}$ A expressão "cavaleiro branco" é utilizada, segundo João Pedro Barroso do Nascimento, "em alusão às batalhas medievais, nas quais o cavaleiro branco opunha-se ao cavaleiro negro. Na linguagem dos financeiros, o ofertante contrário à administração da companhia seria o cavaleiro negro, enquanto o ofertante amigável seria o cavaleiro branco" (NASCIMENTO, João Pedro Barroso do, op. cit., p. 154).

${ }_{348}$ Da mesma forma o faz o artigo $9^{\circ}$ (2) da Diretiva $n^{\circ}$ 2004/25/CE.

${ }^{349}$ CA Paris, $1^{\mathrm{e}}$ ch., 27.04.93, JCP 93, E, 457, note A. Viandier. Tradução livre: "uma vantagem determinando antecipadamente o sucesso da oferta pública e distorcendo o jogo das ofertas e das melhorias das ofertas pelo ofertante".

${ }^{350}$ VIANDIER, Alain, op. cit., p. 362. Tradução livre: "foi criado o hábito de ver, nesse caso, uma forma de defesa, se não para a sociedade, ao menos para os administradores".
} 
companhia, é dever do administrador, decorrente dos artigos 153 a 158 da LSA, a procura de ofertante para o lançamento de oferta concorrente ${ }^{351}$.

Em princípio, considerando que, no Brasil, assim como já mencionado, a oferta concorrente deve ser lançada por preço no mínimo 5\% superior ao da OPA com que concorrer, conforme o disposto no artigo 13, §3º da Instrução CVM n $361 / 02$, a adoção da medida defensiva em questão traria uma vantagem aos acionistas da companhia visada, na medida em que, nas palavras de João Pedro Barroso do Nascimento, maximizaria "o valor da negociação de suas ações diante de potencial tomada de controle" 352 . No entanto, bem lembra João Pedro Barroso do Nascimento da experiência norte-americana, que mostra, como a seguir indicado, que existem situações em que a negociação entre a administração da companhia objeto e o cavaleiro branco pode estar relacionada à previsão de privilégios concedidos pela companhia objeto ao cavaleiro branco.

\footnotetext{
"Entretanto, a experiência norte-americana revela que há ocasiões em que a negociação entre a administração da companhia alvo e o cavaleiro branco pode estar associada à previsão de privilégios conferidos pela companhia-alvo ao cavaleiro branco, inclusive no que tange ao tratamento diferenciado no ambiente negocial, consistente no compromisso de recomendação aos acionistas para a aceitação da proposta realizada pelo cavaleiro branco. Em contrapartida, o cavaleiro branco assume o compromisso de não substituir os membros da administração da companhia-alvo, caso seja concretizada a tomada de controle da companhia-alvo pelo cavaleiro branco" ${ }^{, 353}$.
}

A postura mencionada é desaconselhada nos EUA pela doutrina, que alega existir violação do dever fiduciário dos administradores em maximizar o valor de negociação das ações de emissão da companhia visada, para privilegiar interesse referente à conservação dos seus $\operatorname{cargos}^{354}$.

No mesmo sentido, mas com base no princípio do livre jogo das ofertas e no princípio da igualdade na competição, a doutrina francesa entende que os administradores

\footnotetext{
${ }^{351}$ NASCIMENTO, João Pedro Barroso do, op. cit., p. 156.

${ }^{352}$ NASCIMENTO, João Pedro Barroso do, op. cit., p. 154.

${ }^{353}$ Idem, ibidem.

${ }^{354}$ Idem, p. 154-155.
} 
da companhia visada não devem conceder vantagens determinantes ao cavaleiro branco ${ }^{355}$. E que, caso haja a comunicação de informação privilegiada pelos administradores da companhia ao cavaleiro branco, este deverá mencionar referida informação na nota de informação por ele elaborada, a fim de restabelecer a igualdade de informação entre os investidores ${ }^{356}$.

\title{
4.2.3.2 Defesa Pac-Man ${ }^{357}$.
}

Trata-se de uma contraoferta, realizada pela companhia visada ou por terceiro por meio do lançamento de uma oferta sobre as ações de emissão da companhia ofertante ${ }^{358}$.

João Pedro Barroso do Nascimento bem resume a defesa em questão da seguinte forma:

\begin{abstract}
"Tal medida consiste em contra-ataque da companhia alvo direcionado ao ofertante. Isto é, enquanto a companhia-alvo é atacada pelo ofertante hostil, que pretende adquirir seu controle por meio de oferta pública, ela contra-ataca o ofertante hostil, tentando adquirir-lhe o controle acionário, em aplicação prática do provérbio latino 'si vis pacem, para bellum' (se queres a paz, prepara-te para a guerra) $)^{, 359}$.
\end{abstract}

Na legislação francesa, há um obstáculo à realização da medida de defesa ora analisada, qual seja a proibição das participações cruzadas ${ }^{360}$. Existem, ainda, algumas dificuldades no que se refere ao calendário da oferta, já que, diferentemente do que ocorre com a oferta concorrente ${ }^{361}$, por exemplo, a contraoferta não ocasionará, nas palavras de

\footnotetext{
${ }^{355}$ MARTIN, Didier; MOLFESSIS, Nicolas, op. cit., p. 612.

${ }^{356}$ Idem, ibidem.

357 Segundo o Black's Law Dictionary, a expressão pac-man defense significa "an agressive antitakeover defense by which the target company attempts to take over the bidder company by making a cash tender offer for the bidder company's shares. The name derives from a video game popular in the 1980s, the object of which was to gobble up the enemy. This defense is seldom used today (GARNER, Bryan A. Black's Law Dictionary. 4. ed. Saint Paul: West Group, 2001, p. 1133).

${ }^{358}$ NASCIMENTO, João Pedro Barroso do, op. cit., p. 163.

${ }^{359}$ Idem, ibidem.

${ }^{360}$ No direito brasileiro, a participação recíproca encontra-se disciplinada no artigo 244 da LSA.

${ }^{361}$ É importante ressaltar que a oferta pública concorrente e a contraoferta ora analisada não se confundem, tanto no direito brasileiro como no francês. João Pedro Barroso do Nascimento bem diferencia as duas da seguinte forma: "Enquanto a oferta concorrente tem por objeto a companhia-alvo simultaneamente à(s) outra(s) oferta(s) pública(s) de aquisição de controle da companhia-alvo, a defesa pac-man é uma oferta pública realizada pela companhia alvo tendo como objetivo adquirir o controle da companhia que estiver,
} 
Didier Martin, “automatiquement l'allongement du calendrier de l'offre initiale",362. Essa questão deve ser analisada com cuidado, levando, também, em conta que a medida de defesa em questão deverá ser autorizada pela assembleia geral de acionistas, salvo se aplicada a exceção de reciprocidade ${ }^{363}$. Além disso, a coexistência de duas ofertas públicas “cruzadas" levará, na opinião de Didier Martin, à retirada, ao final, de uma delas, o que contraria o princípio da irrevogabilidade das ofertas públicas ${ }^{364}$.

Diante disso, para se lançar uma contraoferta, é preciso que se considere o importante investimento por parte da companhia visada, o qual pode não ser justificado do ponto de vista do interesse social ${ }^{365}$.

A defesa ora analisada pode ser empregada no sistema jurídico brasileiro, devendo ser respeitadas as regras aplicáveis às ofertas públicas voluntárias ${ }^{366}$. Como bem lembra João Pedro Barroso do Nascimento, a aplicabilidade da medida de defesa em questão pressupõe, primeiramente, que a companhia ofertante seja também companhia aberta e, após, que possua estrutura de capital "dotada de dispersão acionária"367.

\subsubsection{Bônus de subscrição.}

De acordo com a doutrina francesa, a inovação mais importante da Lei $\mathrm{n}^{\circ}$ 2006387, de 31 de março de 2006, residiu na introdução do mecanismo de defesa da companhia visada referente à emissão de bônus de subscrição ${ }^{368369}$. Tal mecanismo foi analisado como uma verdadeira pilule empoisonnée, podendo dificultar a tomada de controle da companhia

concomitantemente, tentando adquirir o seu controle" (NASCIMENTO, João Pedro Barroso do, op. cit., p. 164).

${ }^{362}$ MARTIN, Didier; MOLFESSIS, Nicolas, op. cit., p. 616.

${ }^{363}$ Idem, ibidem.

${ }^{364}$ Idem, ibidem.

365 Idem, ibidem.

${ }^{366}$ NASCIMENTO, João Pedro Barroso do, op. cit., p. 164.

${ }^{367}$ Idem, ibidem.

${ }^{368}$ Os bônus de subscrição são valores mobiliários que conferem ao seu titular o direito de subscrever ações de emissão da companhia (artigo L. 233-32, II, do C. com.). O artigo mencionado permite a atribuição gratuita dos bônus aos acionistas da companhia, que terão direito de preferência no exercício dos direitos a eles inerentes.

369 Como já mencionado, a Aventis, quando da OPA lançada por Sanofi-Synthélabo, desejou emitir mencionados valores mobiliários, o que foi julgado pela AMF contrário aos princípios disciplinadores das ofertas públicas de aquisição. 
por meio, por exemplo, da diluição da participação acionária ${ }^{370}$, além de ter sido criado para atender, principalmente, ao seguinte objetivo ${ }^{371}$ : disponibilizar importantes meios de negociação ${ }^{372}$ e de defesa, no caso de OPA, sempre respeitando as regras de governança corporativa $^{373}$.

De acordo com o artigo L. 233-32, II, do C. com., sem prejuízo de outras medidas legalmente permitidas, a assembleia geral extraordinária da companhia visada, deliberando de acordo com as condições de quorum previstas para a assembleia geral ordinária, pode decidir pela emissão de bônus de subscrição ${ }^{374}$. A decisão da emissão dos bônus de subscrição, como mencionado, é de competência da assembleia geral de acionistas, que pode delegar sua competência ao conselho de administração ou ao directoire, conforme o caso. A delegação em questão somente será válida se respeitadas as seguintes condições: a delegação deve ter sido realizada, no máximo, nos 18 meses que antecederam a apresentação do projeto de oferta $^{375}$ e a companhia visada deve valer-se da exceção de

${ }^{370}$ Assim afirma Anne-Valérie Le Fur: "En cas de suite positive de l'offre, ces bons permettent alors de souscrire à des actions nouvelles à un prix largement inférieur au cours de bourse; l'effet dilutif à l'égard de l'initiateur est immédiat" (LE FUR, Anne Valérie. Les bons d'offre: une mesure de défense conforme au gouvernement d'entreprise. Bulletin Joly Bourse, Paris, 2007, p. 714). Tradução livre: “Caso a oferta seja bem sucedida, tais bônus permitem a subscrição de novas ações a um preço amplamente inferior ao preço de mercado; o efeito de diluição em relação ao ofertante é imediato".

${ }^{371}$ Decorre disso, segundo Martin Laprade, uma característica importante do mecanismo em questão: tais bônus são extintos de pleno direito, quando a oferta, por exemplo, não for bem sucedida (LAPRADE, Frank Martin; GIULIANI, Guillaume. La réforme des offres publiques d'acquisition. Revue de droit bancaire et financier, n. 6, 2006, p. 68).

${ }^{372}$ As lições de Christophe Clerc são no mesmo sentido: "L'objectif législatif est clair: il s'agit de conforter la position de négociation de la société cible, pour lui permettre d'obtenir les meilleurs conditions possibles. Cette règle conduira ainsi l'auteur de l'offre et la cible à négocier, le premier pour s'assurer une prise de contrôle sans aléas, surcoûts ni opposition frontale de toutes les parties prenantes, la seconde pour optimiser le prix et les conditions de l'offre" (CLERC, Christophe. Les bons d'offre au cœur de la transposition de la directive OPA. Revue trimestrielle de droit financier, Paris, n. 1, 2006, p. 32). Tradução livre: "o objetivo legislativo é claro: trata-se de fortalecer a posição de negociação da companhia objeto, permitindo-lhe as melhores condições possíveis. Tal regra conduzirá o ofertante e a companhia visada a negociarem, a fim de assegurar uma tomada de controle sem riscos, custos adicionais e oposição frontal de todos os interessados, bem como para otimizar o preço e as condições da oferta".

${ }^{373}$ Nessa linha, afirma Didier Martin que “(...) dans l'esprit du Gouvernement, le mécanisme des bons d'offre mis en place par la loi OPA constitue essentiellement un instrument de négociation et de dissuasion destiné à renforcer la main du conseil d'administration de la société cible dans ses discussions avec l'initiateur de l'offre, et à inciter cet initiateur à améliorer les termes de son offre" (MARTIN, Didier; MOLFESSIS, Nicolas, op. cit., p. 621). Tradução livre: “(...) no espírito do Governo, o mecanismo dos bônus de subscrição, instituído pela Lei OPA, constitui essencialmente um instrumento de negociação e de dissuasão destinado a fortalecer o conselho de administração da companhia objeto em suas discussões com o ofertante e a incentivar este a melhorar as condições de sua oferta".

374 Tradução livre: "sobre a emissão de bônus permitindo a subscrição, em condições preferenciais, de ações de emissão da sociedade e sua atribuição gratuita a todos os seus acionistas antes do término do período da oferta pública".

${ }^{375}$ Artigo L. 233-33, al. 2, C. com. Na realidade a assembleia geral de acionistas poderá ser realizada, também, durante a OPA. A exigência relativa ao prazo de 18 meses se refere à assembleia geral realizada antes da realização da OPA. Eis o que explica Christophe Clerc: "Le vote de l'assemblée pourra avoir lieu 'à 
reciprocidade, prevista no artigo L. 233-33 do C. com. Consequentemente, a delegação é válida apenas se o ofertante não aplica o princípio da neutralidade dos administradores (durante a OPA), previsto no artigo L. 233-32 do C. com.

A regra em questão demonstra certa contradição na legislação francesa, já que a mudança legislativa mais recente à época demonstrava reticência com relação às técnicas de defesa contra a OPA ${ }^{376}$. Prova disso é que foi suprimida em $2004^{377}$ a possibilidade de delegação de competência no caso de aumento de capital, durante a oferta pública de aquisição. A Lei no 2006-387, de 31 de março de 2006, restabeleceu esse regime, inserindo também o mecanismo de bônus de subscrição ora analisado. Para alguns autores, o mecanismo contraria, mesmo que aplicando o mecanismo de reciprocidade, o princípio da neutralidade dos administradores, pois, havendo delegação de competência, o conselho de administração ou o directoire poderá decidir pela emissão dos bônus de subscrição.

A delegação de competência é disciplinada e enquadrada pela Lei, não possuindo o conselho de administração ou o directoire, grande margem de manobra. Porém, há como negar que foi reforçado o papel do conselho de administração no que se refere à negociação com a companhia visada ${ }^{378}$.

No direito brasileiro, os bônus de subscrição, regulados nos artigos 75 a 79 da LSA, são de emissão privativa das companhias de capital autorizado ${ }^{379}$, conferindo ao seu titular o direito de subscrever ações de emissão da companhia, mediante o pagamento do respectivo preço de emissão.

froid', c'est-à-dire, par exemple, lors des assemblées annuelles. La délégation ainsi consentie ne pourra être utilisée que dans le cadre de l'exception de réciprocité. Pour être valablement utilisée, la délégation devra avoir été consentie 'dans les dix-huit mois précédant le jour du dépôt de l'offre'. La jurisprudence devrait naturellement conduire à un renouvellement annuel de la délégation. Le vote peut aussi intervenir 'à chaud', c'est-à-dire en période d'offre. La délégation peut dans ce cas être utilisée contre tout auteur d'offre" (CLERC, Christophe, op. cit., p. 32). Tradução livre: “o voto da assembleia poderá ocorrer 'a frio', ou seja, quando da realização das assembleias gerais anuais, por exemplo. A delegação consentida poderá ser usada apenas no âmbito da exceção de reciprocidade. Para ser validamente utilizada, a delegação deve ter sido consentido 'nos dezoito meses que precederam o dia do protocolo do projeto de oferta'. A jurisprudência deveria conduzir naturalmente à renovação anual da delegação. O voto pode, ainda, se dar 'a quente', ou seja, no período da oferta. A delegação pode, nesse caso, ser usada contra o ofertante".

${ }^{376}$ LE FUR, Anne Valérie, op. cit., p. 714.

${ }^{377}$ Com a reforma realizada pela Ordonnance no 2004-604, de 24 de junho de 2004.

${ }^{378}$ Artigo L. 233-32, II, do C. com.

${ }^{379}$ Artigo 168 da LSA. 
Os bônus, de acordo com o artigo 77 da LSA, podem ser alienados pela companhia ou por ela atribuídos, como vantagem adicional, aos subscritores de emissões de suas ações ou debêntures. É assegurado aos acionistas da companhia, nos termos dos artigos 171 e 172 da LSA, o direito de preferência para a subscrição dos bônus emitidos ${ }^{380}$. O artigo 171, §3 ${ }^{\circ}$, da LSA reafirma a existência do direito de preferência dos acionistas para subscrição das emissões de bônus de subscrição, não existindo, contudo, tal direito na conversão dos mencionados títulos em ações, por exemplo. A deliberação sobre a emissão de bônus de subscrição compete à assembleia geral de acionistas, exceto se o estatuto a atribuir ao conselho de administração ${ }^{381}$.

Nota-se que, no direito francês, o mecanismo de emissão de bônus de subscrição tal como analisado foi concebido como medida defensiva, tendo sido concedido um importante papel ao conselho de administração. No direito brasileiro, para desempenhar a função de medida defensiva, é preciso, sobretudo, que o capital autorizado seja suficiente para garantir a emissão de ações em quantidade tal que seja possível a defesa contra a tomada de controle ${ }^{382}$.

\footnotetext{
${ }^{380}$ Artigo 77, parágrafo único, da LSA.

${ }^{381}$ Artigo 76 da LSA.

${ }^{382}$ NASCIMENTO, João Pedro Barroso do, op. cit., p. 129.
} 


\section{CAPÍTULO 5 \\ OFERTA PÚBLICA PARA AQUISIÇÃo DO CONTROLE DE COMPANHIA ABERTA NA UNIÃO EUROPEIA.}

\subsection{Histórico da Diretiva no $2004 / 25 / C E$.}

Uma proposta para a $13^{\mathrm{a}}$ Diretiva sobre o direito societário e regulação das ofertas públicas foi apresentada, em 19 de janeiro de 1985, pela Comissão Europeia ao Conselho da União Europeia e ao Parlamento Europeu ${ }^{383}$. Em seu Livro Branco sobre a conclusão do mercado interno, de 1985, a Comissão demonstrou a necessidade de se unificarem as legislações dos Estados-Membros quanto às ofertas públicas de aquisição ${ }^{384}$. A referida proposta foi considerada como um texto ambicioso e excessivamente detalhado, visando à uma verdadeira unificação das legislações. Alguns Estados-Membros se mostraram reticentes com relação ao texto em questão, tendo sido esse primeiro projeto abandonado.

A Comissão, em fevereiro de 1996, apresentou uma segunda proposta de Diretiva n $2004 / 25 / C E$, a qual previa, sobretudo, princípios gerais, cabendo aos Estados-Membros a implantação e a aplicação de tais princípios. Em uma primeira análise, a proposta em questão foi aprovada tanto pelo Parlamento Europeu como pelo Comitê Econômico e Social. Entretanto, foi rejeitada, num outro momento, pelo Parlamento, o que demonstra o aspecto político da Diretiva em questão, bem como o caráter sensível do assunto por ela tratado. A questão mais polêmica se referia ao fato de os administradores serem obrigados a obter a autorização dos acionistas antes de decidirem sobre a adoção de técnicas de

\footnotetext{
383 JOCE, de 14 de março de 1989, C 64, p. 8.

${ }^{384}$ Nesse sentido, afirma a Comissão Europeia: "Il y a également lieu d'améliorer l'usage qui est fait de certaines procédures comme les offres d'actions au public pour remodeler la structure des participations dans les entreprises, puisque les règles actuellement en vigueur dans ce domaine varient très largement d'un pays à l'autre. Ces opérations devraient également être rendues plus attrayantes. On pourrait y parvenir en exigeant un minimum de garanties, notamment en ce qui concerne l'information à communiquer aux intéressés, tandis que les Etats membres resteraient libres de fixer la procédure de surveillance de ces opérations et de désigner les autorités auxquelles seraient confiés les pouvoirs de surveillance. Une proposition sera faite en ce sens en 1987 et les décisions nécessaires devraient être prises pour 1989" (Disponível em: <http://europa.eu/documents/comm/white_papers/pdf/com1985_0310_f_fr.pdf>, p. 35. Acesso em: 26.05.11). Tradução livre: "Há também a necessidade de melhorar a utilização de certos procedimentos, tais como as ofertas de ações ao público, a fim de reformular a estrutura da participações nas empresas, já que as regras atualmente em vigor variam muito de um país para o outro. Devem, ainda, tais operações ser mais atraentes, o que poderia ser conseguido, exigindo garantias mínimas, notadamente com relação à informação a ser comunicada aos interessados, ficando os Estados-Membros livres para fixar o procedimento de supervisão das operações e para designar as autoridades às quais seriam confiados os poderes de fiscalização. Uma proposição será feita nesses termos em 1987 e as decisões necessárias devem ser tomadas em 1989”.
} 
defesa contra OPA hostil (princípio da neutralidade dos administradores) ${ }^{385}$. Alguns deputados europeus temiam que tal regra impedisse a companhia visada de se defender corretamente $^{386}$.

Uma terceira proposta de Diretiva foi apresentada em $2002^{387}$, pela Comissão, seguindo recomendações de um groupe d'experts de haut niveau dirigido pelo Professor Winter. Esse grupo tinha como objetivo: a manutenção do alto padrão de proteção aos acionistas; a definição, nas ofertas obrigatórias, do preço justo a ser pago; a introdução do procedimento de aquisição de ações de acionistas remanescentes após a oferta.

Depois de algumas adaptações, visando, principalmente, a tornar algumas de suas disposições mais flexíveis ${ }^{388}$, a proposta foi finalmente aprovada, em 21 de abril de 2004, gerando a Diretiva ${ }^{\circ}$ 2004/25/CE.

\footnotetext{
${ }^{385}$ Erik Frederico Oioli aponta que, em uma segunda análise, foram identificados três principais problemas, a seguir indicados: "(i) falta de harmonização da legislação de Estados membros da UE; (ii) introdução do princípio pelo qual os acionistas deveriam decidir sobre a adoção de técnicas de defesa (também conhecido como princípio da neutralidade dos administradores); e (iii) ausência de medidas específicas para proteção dos empregados nas takeovers bids" (OIOLI, Erik Frederico. Oferta pública de aquisição do controle de companhias abertas. São Paulo: Quartier Latin, 2010, p. 111).

386 TEHRANI, Adrien. Les clauses de préemption et la directive 2004/25/CE du 21 avril 2004 concernant les offres publiques d'acquisition: contribution à l'étude des restrictions au transfert des titres de sociétés cotées. Paris, 2005. Mémoire d'admission DESS de droit des affaires - DJCE. Université Paris II. Disponível em <mja-paris2.webs.com/MEMOIRES\%202005/Adrien_TEHRANI.doc>, p. 8. Acesso em: 26.05.11

387 Proposta de Diretiva, datada de 02.10.2002, JOUE, de 25 de fevereiro de 2003.

${ }^{388}$ Isso se refere, sobretudo, à delicada questão da adoção de técnicas de defesa contra OPA hostil. A tentativa em questão criticada por muitos autores, já que, em razão dela, a tão desejada harmonização das legislações restou, de certa maneira, prejudicada. Assim afirmam Anne Maréchal e Alain Pietrancosta: "Résultat d'une négociation longue et tumultueuse, la directive communautaire doit son salut, on le sait, au compromis trouvé sur la délicate question des défenses anti-OPA. Tenant compte de l'hostilité de nombreux États membres au 'désarmement' de leurs entreprises programmé par les articles 9 et 11 du projet de directive, eu du risque notamment de son unilatéralité face à des entreprises extra-communautaires jugées mieux dotées, ce compromis, proposé en juin 2003 par la délégation portugaise et adopté en octobre suivant par la présidence italienne, aboutit au système de 'double option' inscrit à l'article 12 du texte final, baptisé 'arrangements facultatifs'. Appauvrissant la portée obligatoire, et donc l'ambition harmonisatrice, de la directive sur ce sujet capital, un dispositif 'à la carte' ou à 'géométrie variable' innovant et complexe, est institué, qui renvoie largement à l'appréciation des États membres et, subsidiairement, à celle de leurs sociétés ressortissantes" (MARÉCHAL, Anne; PIETRANCOSTA, Alain. Transposition de la Directive OPA: des incertitudes entourant le recours à la "clause de réciprocité". Bulletin Joly Bourse, Paris, 2005, p. 797). Tradução livre: "Resultado de uma negociação longa e tumultuada, a Diretiva da UE foi finalmente aprovada graças ao compromisso sobre a delicada questão das defesas anti-OPA. Considerando a hostilidade de diversos Estados-Membros com relação ao 'desarmamento' de suas empresas programado pelos artigos 9 e 11 do projeto de diretiva e do risco, notadamente, de sua unilateralidade face às empresas extracomunitárias julgadas melhor dotadas, mencionado compromisso, proposto em junho de 2003 pela delegação portuguesa e adotado em outubro do mesmo ano pela presidência italiana, conduziu a um sistema de 'dupla opção' constante do artigo 12 do texto final, batizado de 'acordos facultativos'. Empobrecendo o caráter obrigatório e, pois, a ambição de harmonização da diretiva sobre esse assunto fundamental, um dispositivo 'à escolha' ou à 'geometria variável' inovador e complexo foi instituído, possuindo os Estados-Membros e, subsidiariamente, suas sociedades importante margem de apreciação".
} 
Serão estudadas as principais regras sobre a OPA na UE, bem como a transposição da citada Diretiva, no direito francês.

\subsection{Principais disposições.}

\subsubsection{Autoridade competente para a supervisão da oferta e outras regras.}

Cabe aos Estados-Membros designar a autoridade competente para a supervisão das ofertas públicas disciplinadas por regras já estabelecidas ou introduzidas em aplicação da Diretiva n ${ }^{\text {o }}$ 2004/25/CE ${ }^{389}$.

A autoridade competente para a supervisão da oferta é a do Estado-Membro, no qual se situa a sede social da companhia visada, se os valores mobiliários de sua emissão estiverem admitidos à negociação em mercado regulamentado desse mesmo EstadoMembro $^{390}$.

Caso os valores mobiliários da companhia visada não estejam admitidos à negociação em mercado regulamentado do Estado-Membro em que se situa a sede social da companhia, a autoridade competente para a supervisão da oferta é a do Estado-Membro em cujo mercado regulamentado os valores mobiliários estejam admitidos à negociação ${ }^{391}$.

A referida autoridade de supervisão precisa dispor de todos os poderes necessários para o exercício das suas funções, entre os quais se inclui o de assegurar que as partes envolvidas na oferta observem as regras aprovadas ou introduzidas em aplicação da Diretiva ${ }^{\circ}$ 2004/25/CE ${ }^{392}$.

\footnotetext{
${ }^{389}$ Artigo $^{\circ}$ (1) da Diretiva $n^{\circ}$ 2004/25/CE.

${ }^{390}$ Artigo $4^{\circ}$ (2) da Diretiva $n^{\circ}$ 2004/25/CE.

391 Artigo $4^{\circ}$ (2) da Diretiva $n^{\circ}$ 2004/25/CE. Complementa o dispositivo em questão que caso os valores mobiliários da companhia visada estejam admitidos à negociação em mercados regulamentados de mais de um Estado-Membro, a autoridade competente para a supervisão da oferta é aquela do Estado-Membro em cujo mercado regulamentado os valores mobiliários tiverem sido admitidos à negociação primeiramente. Na hipótese de a primeira admissão à negociação dos valores mobiliários da companhia visada ter ocorrido em simultâneo em mercados regulamentados de mais de um Estado-Membro, a companhia visada deve determinar qual a autoridade competente para a supervisão da oferta, notificando esses mercados regulamentados e as respectivas autoridades de supervisão, no primeiro dia de negociação.

${ }^{392}$ Artigo $4^{\circ}$ (5) da Diretiva $n^{\circ}$ 2004/25/CE.
} 
É de responsabilidade dos Estados-Membros assegurar que a decisão de lançar uma oferta seja imediatamente tornada pública, devendo a autoridade de supervisão ser dela informada ${ }^{393}$. Logo que a oferta seja tornada pública, devem os órgãos de administração da companhia visada e do ofertante informar os respectivos representantes dos trabalhadores ou, na sua falta, os próprios trabalhadores ${ }^{394}$.

Com o objetivo de informar e dar transparência à operação ${ }^{395}$, determina a Diretiva $n^{\circ}$ 2004/25/CE que os Estados-Membros devem garantir que o ofertante se sujeite à obrigação de elaborar e divulgar, em tempo oportuno, um documento sobre a oferta, contendo informações necessárias, a fim de permitir que os titulares de valores mobiliários da companhia visada tomem conhecimento da oferta ${ }^{396}$. Constarão do referido documento algumas informações, tais como ${ }^{397}$ : os termos da oferta; a identificação do ofertante; os valores mobiliários objeto da oferta, incluindo os percentuais mínimos ou máximos de aquisição, quando se tratar de ofertas parciais; a forma de pagamento; as condições a que a oferta está subordinada; o prazo da aceitação da oferta; as intenções do ofertante quanto à continuação da atividade da companhia visada e quanto à manutenção do emprego dos respectivos trabalhadores e dirigentes; as informações sobre o financiamento da oferta.

No que diz respeito ao prazo de aceitação da oferta, é preciso que seja fixado entre duas a dez semanas, a contar da data de publicação do projeto de oferta ${ }^{398}$. Sem prejuízo do princípio segundo o qual a companhia visada não deve, em virtude de uma oferta pública, ser perturbada no exercício da sua atividade para além de um período razoável ${ }^{399}$, os Estados-Membros podem estabelecer a possibilidade de prorrogação do prazo de dez semanas, devendo o ofertante notificar, com antecedência mínima de, pelo menos, duas semanas, a sua intenção de encerrar a oferta ${ }^{400}$.

\footnotetext{
${ }^{393}$ Artigo $6^{\circ}$ (1) da Diretiva $n^{\circ}$ 2004/25/CE.

${ }^{394}$ Artigo $^{\circ}$ (1) da Diretiva $n^{\circ}$ 2004/25/CE.

395 A preocupação de publicidade e transparência no que se refere à oferta aparece, também, no artigo $8^{\circ}(1)$ da Diretiva $n^{\circ}$ 2004/25/CE, que determina que devem os Estados-Membros assegurar que a oferta seja tornada pública, a fim de garantir a transparência e a integridade do mercado, evitando a publicação ou divulgação de informações falsas ou enganosas.

${ }^{396}$ Artigo $^{\circ}$ (2) da Diretiva n ${ }^{\circ}$ 2004/25/CE.

${ }^{397}$ Artigo $^{\circ}$ (3) da Diretiva $n^{\circ}$ 2004/25/CE.

${ }^{398}$ Artigo $7^{\circ}$ (1) da Diretiva $n^{\circ}$ 2004/25/CE.

399 Artigo $3^{\circ}$ (1), "f", da Diretiva n ${ }^{\circ}$ 2004/25/CE.

${ }^{400}$ Artigo $7^{\circ}$ (1) da Diretiva $n^{\circ}$ 2004/25/CE.
} 


\title{
5.2.2 Princípio da neutralidade dos administradores e outras regras ${ }^{401}$.
}

Os deveres dos órgãos de administração constam do artigo $9^{\circ}$, o qual, nas palavras de Anne Maréchal, "s'intéresse aux défenses réactives (post-OPA) et définit un régime européen de gouvernance d'entreprise en période d'offre" ${ }^{\text {"402 }}$.

Segundo o artigo $9^{\circ}$ (2) da Diretiva $n^{\circ}$ 2004/25/CE, qualquer atitude adotada durante a oferta pública que seja suscetível de frustrá-la deve ser aprovada pelos acionistas da companhia visada, com exceção da procura de oferta concorrente.

Como já descrito, um dos principais pontos de divergência, quando da elaboração da Diretiva $n^{\circ}$ 2004/25/CE, foi o das técnicas de defesa contra OPA hostil (incluindo o princípio da neutralidade dos administradores). Lembra Didier Martin, como abaixo indicado, que a adoção pela companhia visada de qualquer medida de defesa destinada a frustrar a oferta suscitou intensos debates parlamentares e muito se escreveu a respeito na doutrina:

\begin{abstract}
"L'adoption par la société cible d'une offre publique hostile de mesures de défense destinées à faire échec à l'offre est probablement la question qui, lors de l'adoption de la loi nº 2006-387 du 31 mars 2006 (la 'loi OPA') transposant la directive $\mathrm{n}^{\circ}$ 2004/25 du 21 avril 2004 concernant les offres publiques d'acquisition (la 'directive OPA') a suscité les débats parlementaires les plus vifs et fait couler le plus d'encre en doctrine" ${ }^{403}$.
\end{abstract}

A divergência conduziu, nas palavras de Didier Martin, "à une harmonisation $a$ minima des droits des États membres en matière d'offre publique laissant une large place à la subsidiarité des États membres" ${ }^{404}$, harmonisação essa resultante de um compromisso havido entre os Estados-Membros, o qual se verifica pelo artigo 12 da Diretiva $\mathrm{n}^{\circ}$

\footnotetext{
${ }^{401}$ De acordo com o artigo $9^{\circ}$ (6) da Diretiva $n^{\text {o }}$ 2004/25/CE, entende-se por órgão de administração o conselho de administração ou o conseil de surveillance, conforme o caso.

${ }^{402}$ MARÉCHAL, Anne; PIETRANCOSTA, Alain, op. cit., p. 798.

${ }^{403}$ MARTIN, Didier; MOLFESSIS, Nicolas, op. cit., p. 573. Tradução livre: “A adoção pela companhia visada de medidas de defesa suscetíveis de frustrar a oferta é, provavelmente, a questão que, quando da adoção da Lei 2006-387, de 31 de março de 2006 (la 'Loi OPA') transpondo a Diretiva n’ 2004/25 de 21 de abril de 2004 referente às ofertas públicas de aquisição (a 'Diretiva OPA'), suscitou os mais vivos debates no Parlamento e na doutrina".

${ }^{404}$ Idem, p. 575. Tradução livre: "à uma harmonização a minima dos Estados-Membros com relação à oferta pública, deixando um importante espaço à subsidiariedade dos Estados-Membros".
} 
2004/25/CE ${ }^{405}$, concedendo aos Estados-Membros a faculdade de não exigirem das companhias cujas sedes se encontram em seus territórios o cumprimento das regras constantes do artigo $9^{\circ}$ (2) (3), desde que referidas companhias possam aplicá-las, caso queiram. Ademais, prevê o artigo 12 (3) da Diretiva $n^{\circ}$ 2004/25/CE um mecanismo, também facultativo, de reciprocidade, podendo a sociedade que aplicar as regras constantes do artigo $9^{\circ}$ (2) (3) excepcioná-las, quando o ofertante não adotá-las ou quando o controlador direto ou indireto do ofertante não adotá-las (mecanismo ou exceção de reciprocidade).

Vale ressaltar, ainda, que cabe ao órgão de administração da companhia visada a elaboração e a publicação de um documento do qual conste seu parecer fundamentado sobre a oferta, especificamente quanto às repercussões da oferta sobre os interesses da companhia, incluindo o emprego e seus níveis, bem como quanto aos planos estratégicos do ofertante para a companhia visada. Deve o órgão de administração da companhia visada apresentar o parecer em questão aos representantes dos trabalhadores da companhia ou, na sua falta, aos próprios trabalhadores ${ }^{406}$.

\subsubsection{Não oponibilidade das restrições ("neutralização das restrições").}

A questão da não oponibilidade das restrições em matéria de transmissão de valores mobiliários e de direito de voto é tratada pela Diretiva no 2004/25/CE no artigo 11, o qual se concentra, sobretudo, nas técnicas de defesa preventivas e possui como objetivo neutralizar as restrições estatutárias e contratuais relativas à transferência de valores mobiliários e de direito de voto. Eis o que explica Anne Maréchal:

\footnotetext{
“L’article 11, quant à lui, centré davantage sur les défenses préventives (préOPA), entend neutraliser les restrictions statutaires et contractuelles au transfert de titres et au droit de vote, et institue la fameuse 'break-through rule', dont l'objet consiste à désamorcer automatiquement ces défenses, ainsi que celles
}

\footnotetext{
${ }^{405}$ Prevê o artigo 12 (1) da Diretiva no 2004/25/CE que "os Estados-Membros podem reservar o direito de não exigir que as sociedades a que se refere o $\mathrm{n}$. 1 do artigo $1^{\circ}$, com sede social nos respectivos territórios, apliquem o disposto nos ns. 2 e 3 do art. $9^{\circ}$ e/ou no art. $11^{\circ}$ '. O mecanismo de reciprocidade está previsto no artigo 12 (2) da Diretiva $n^{\circ}$ 2004/25/CE, nos seguintes termos: "Sempre que os Estados-Membros façam uso da faculdade a que se refere o n. 1, devem, no entanto, dar às sociedades com sede social nos respectivos territórios a opção, que deve ser reversível, de aplicar o disposto nos ns. 2 e 3 do artigo $9^{\circ}$ e/ou do artigo $11^{\circ}$, sem prejuízo do disposto no n. 7 do artigo $11^{\circ "}$.

406 Artigo 9 (5) da Diretiva n ${ }^{\circ}$ 2004/25/CE.
} 
concernant la nomination ou la révocation de membres de l'organe d'administration ou de direction, lorsque l'offrant vient à détenir un nombre de titres lui permettant de modifier les statuts de la société cible"407.

Trata-se de outro ponto de divergência. O artigo em questão, bem como o artigo $9^{\circ}$ da Diretiva $n^{\circ}$ 2004/25/CE acima estudado, provocaram a "ira" de certos EstadosMembros e foi necessário celebrar referido compromisso, materializado no artigo 12 da Diretiva no $2004 / 25 / \mathrm{CE}^{408}$.

Como consta do artigo 11 da Diretiva $n^{\circ}$ 2004/25/CE, a neutralização das restrições em matéria de transmissão de valores mobiliários e de direito de voto se refere a duas etapas da OPA, quais sejam: o período da aceitação oferta, bem como a assembleia geral de acionistas que tomar uma decisão sobre eventuais medidas de defesa nos termos do $\operatorname{artigo} 9^{\circ}$ da Diretiva $n^{\circ}$ 2004/25/CE.

No tocante à primeira, dispõe o artigo 11 (2) da Diretiva $n^{\circ}$ 2004/25/CE que as restrições à transmissão de valores mobiliários previstas no estatuto social da companhia visada não são aplicáveis ao ofertante durante o período de aceitação da oferta previsto no artigo $7^{\circ}$ (1) da Diretiva ${ }^{\circ}$ 2004/25/CE.

\footnotetext{
${ }^{407}$ MARÉCHAL, Anne; PIETRANCOSTA, Alain, op. cit., p. 798. Tradução livre: “O artigo 11, por sua vez, focado mais nas defesas preventivas (pré-OPA), visa a neutralizar as restrições estatutárias e contratuais impostas à transferência de valores mobiliários e de direitos de voto e institui a famosa 'break-through rule' cujo objetivo consiste em neutralizar automaticamente tais defesas, bem como aquelas relativas à nomeação ou destituição dos membros do órgão de administração ou de direção, quando o ofertante passa a deter certo número de valores mobiliários que lhe permita modificar o estatuto social da companhia visada".

${ }^{408}$ Nesse sentido, entende Marie-Noëlle Dompé: “La primauté de l'assemblée générale des actionnaires, (...), a abouti à l'article 9. L'article 11, pour sa part, a pour objet neutraliser les restrictions aux transferts des titres ou à l'exercice des droits de vote lors des assemblées générales réunies en cours d'offre et à l'issue d'une offre réussie. Ces deux dispositions ont suscité l'ire de certains États et un compromis a dû être trouvé qui est transcrit dans l'article 12. Cette disposition rend optionnelle la transposition, dans les droits internes, des articles 9 et 11 et permet aux États membres d'ouvrir à leurs sociétés la possibilité de ne pas appliquer les articles 9 et 11 si elles sont l'objet d'une offre déposée par une société qui ne les applique pas: c'est la clause de réciprocité" (DOMPÉ, Marie-Noëlle. La transposition de la directive OPA et les principes directeurs des offres. Droit des sociétés, Paris, n. 11, 2006, p. 5). Tradução livre: "A primazia da assembleia geral de acionistas, (...), resultou no artigo 9. O artigo 11, por sua vez, tem como objetivo neutralizar as restrições impostas à transferência de valores mobiliários ou ao exercício dos direitos de voto, quando da realização, durante a oferta, das assembleias gerais. Mencionados dispositivos causaram a ira de certos Estados e um compromisso, constante do artigo 12, precisou ser negociado. Conforme o artigo 12, é opcional a transposição, para o direito interno, dos artigos 9 e 11. Além disso, os Estados podem conferir às suas sociedades a possibilidade de não aplicar os artigos 9 e 11, caso elas sejam o objeto de uma oferta pública lançada por uma sociedade que não aplica mencionados dispositivos: é a cláusula de reciprocidade".
} 
Ademais, as restrições à transmissão de valores mobiliários previstas em contratos entre a companhia visada e os titulares de valores mobiliários de sua emissão ou em contratos entre estes últimos celebrados após a aprovação da Diretiva no 2004/25/CE não se aplicam ao ofertante durante o mencionado prazo de aceitação da oferta.

Quanto à segunda, determina o artigo 11 (3) da Diretiva $n^{\circ}$ 2004/25/CE que as restrições em matéria de direito de voto previstas no estatuto social da companhia visada ficam sem efeito na assembleia geral de acionistas que tomar uma decisão sobre eventuais medidas de defesa, nos termos do artigo $9^{\circ}$ da Diretiva $n^{\circ}$ 2004/25/CE.

Além disso, as restrições em matéria de direito de voto, previstas em contratos entre companhia visada e os titulares de valores mobiliários de sua emissão ou em contratos entre estes últimos celebrados após a aprovação da Diretiva $n^{\circ}$ 2004/25/CE, ficam sem efeito na assembleia geral de acionistas que tomar uma decisão sobre eventual medida de defesa, nos termos do artigo $9^{\circ}$ da Diretiva $n^{\circ}$ 2004/25/CE. Finalmente, prevê o dispositivo em questão que os valores mobiliários com voto plural possuem apenas um voto na assembleia geral de acionistas que decidir sobre eventuais medidas de defesa, nos termos do artigo $9^{\circ}$ da Diretiva $\mathrm{n}^{\circ} 2004 / 25 / \mathrm{CE}^{409}$.

Não obstante, quando após uma oferta, o ofertante detiver, pelo menos, $75 \%$ do capital com direito de voto, não se aplicam as restrições acima indicadas e constantes do artigo 11 (2) (3) da Diretiva $n^{\circ}$ 2004/25/CE, tampouco os direitos especiais de acionistas no que tange à nomeação ou destituição de membros do órgão de administração previstos no estatuto social da companhia visada. Outrossim, os valores mobiliários com voto plural possuem apenas um voto na assembleia geral de acionistas convocada pelo ofertante com o objetivo de alterar o estatuto social ou destituir (ou nomear) membro do órgão de administração ${ }^{410}$. É preciso que haja uma indenização equitativa pelos eventuais prejuízos

\footnotetext{
${ }^{409}$ O artigo 11 (6) da Diretiva $n^{\circ}$ 2004/25/CE prevê que o disposto no artigo em questão não se aplica aos valores mobiliários, caso as restrições ao direito de voto sejam acompanhadas de vantagem pecuniária específica.

${ }^{410}$ Artigo 11 (4) da Diretiva n n $^{2004 / 25 / C E}$. Complementa o dispositivo em questão o seguinte: "Para o efeito, o ofertante deve dispor do direito de convocar uma assembleia-geral de accionistas a curto prazo, na condição de esta assembleia não ocorrer num prazo inferior a duas semanas após a sua convocação". Além disso, igualmente ao previsto para o artigo 11 (3), o artigo 11 (6) determina que o disposto no artigo 11 (4) não se aplica aos valores mobiliários, caso as restrições ao direito de voto sejam acompanhadas de vantagem pecuniária específica.
} 
suportados pelos titulares dos direitos suprimidos, em decorrência do disposto no artigo ora analisado $^{411}$.

Igualmente ao acima indicado para o artigo $9^{\circ}$, o artigo 12 da Diretiva $\mathrm{n}^{\circ}$ 2004/25/CE concede aos Estados-Membros a faculdade de não exigir que as sociedades, cujas sedes se encontrem em seus territórios, apliquem as regras acima mencionadas, desde que referidas sociedades possam aplicá-las, caso queiram. Ademais, o mecanismo de reciprocidade $^{412}$ acima analisado vale também para o artigo 11 da Diretiva $n^{\circ}$ 2004/25/CE.

\subsubsection{Aquisição e alienação potestativa.}

O ofertante tem o direito de exigir que lhe sejam transmitidos os valores mobiliários remanescentes, com base em preço justo ${ }^{413}$, nas seguintes hipóteses: a) quando o ofertante detiver valores mobiliários que representem, pelo menos, $90 \%$ do capital com direito de voto da companhia visada e $90 \%$ dos direitos de voto da companhia ${ }^{414}$ ou b) caso o ofertante tenha adquirido ou celebrado um contrato firme para adquirir, na sequência da aceitação da oferta, valores mobiliários que representem, pelo menos, $90 \%$ do capital da companhia visada com direito de voto e $90 \%$ dos direito de voto ${ }^{415}$.

Se entender exercer o direito em questão, o ofertante deve fazê-lo em três meses, a contar do término do prazo da aceitação da oferta a que se refere o artigo $7^{\circ}$ da Diretiva $\mathrm{n}^{\circ}$ $2004 / 25 / \mathrm{CE}^{416}$.

A fim de proteger os acionistas minoritários e de instituir um mecanismo de retirada da companhia ${ }^{417}$, a Diretiva $n^{\circ}$ 2004/25/CE prevê a alienação potestativa, por meio

\footnotetext{
${ }^{411}$ Artigo 11 (5) da Diretiva no 2004/25/CE.

${ }^{412}$ Artigo 12 (3) da Diretiva n ${ }^{\circ}$ 2004/25/CE.

${ }^{413}$ Artigo 15 (2) da Diretiva n ${ }^{\circ}$ 2004/25/CE.

${ }^{414}$ Podem os Estados-Membros estabelecer um percentual mais alto, mas nunca superior a $95 \%$ do capital com direito de voto e $95 \%$ dos direitos de voto - Artigo 15 (2) da Diretiva n ${ }^{\circ}$ 2004/25/CE.

415 Artigo 15 (2) da Diretiva no 2004/25/CE.

${ }^{416}$ Artigo 15 (4) da Diretiva n ${ }^{\circ}$ 2004/25/CE.

${ }^{417}$ Assim afirma Erik Frederico Oioli: “A prerrogativa de alienação potestativa das ações pelos acionistas remanescentes da companhia, além de ser a contrapartida natural à aquisição potestativa, procura proteger os acionistas minoritários de abusos do novo acionista controlador, bem como assegurar mecanismo apropriado de saída da companhia, uma vez que certamente encontrarão dificuldade para obterem compensações adequadas via alienação de suas ações em um mercado ilíquido. Além disso, essa prerrogativa é um mecanismo apropriado para conter a pressão do acionista em vender suas ações durante a oferta, mitigando o
} 
da qual se confere também ao titular de valores mobiliários remanescentes o poder de exigir que o ofertante proceda à aquisição de seus valores mobiliários, com base em preço justo e seguindo as regras acima indicadas ${ }^{418}$.

\subsection{Transposição da Diretiva no ${ }^{0}$ 2004/25/CE, na França.}

A legislação francesa, em grande parte, já se encontrava em consonância com a Diretiva $n^{\circ} 2004 / 25 / \mathrm{CE}^{419}$. Existiam, contudo, pontos divergentes e algumas lacunas ${ }^{420}$, os quais foram, na medida do possível, resolvidos, quando da transposição da Diretiva ${ }^{\circ}$ 2004/25/CE realizada pela Lei no 2006-387, 31 de março de 2006.

A seguir, serão analisadas as principais modificações realizadas pelo referido texto legal.

\subsubsection{Autoridade de supervisão e direito aplicável.}

Classicamente, no que se refere às OPA, a lei francesa se aplica, levando-se em conta a existência de dois critérios: a sede da companhia e o mercado em que estivessem admitidos à negociação os valores mobiliários. Mencionados critérios não se encontravam formulados expressamente no antigo artigo L. 433-1 do C. mon. fin. ${ }^{421}$.

A situação descrita evoluiu, primeiramente, devido à Lei no 2005-842, de 26 de julho de 2005, que determinou aplicável as regras sobre a oferta pública obrigatória às sociedades cotadas no exterior, quando a participação obtida ${ }^{422}$ constituísse "un actif

problema das decisões distorcidas" (OIOLI, Erik Frederico. Oferta pública de aquisição do controle de companhias abertas. São Paulo: Quartier Latin, 2010, p. 117-118).

${ }^{418}$ Artigo 16 (2) (3) da Diretiva $n^{\circ}$ 2004/25/CE.

${ }^{419}$ Nesse sentido, entende Philippe Merle que a legislação francesa encontrava-se, em grande parte, conforme à diretiva, transposta pela Lei de 31 de março de 2006 (MERLE, Philippe. Droit commercial: sociétés commerciales. 14. ed. Paris: Dalloz, 2010, p. 824-825).

${ }^{420}$ É o que afirma Thierry Bonneau: "Car le droit français, s'il comportait déjà une réglementation désormais bien rodée des OPA, divergeait des règles communautaires, en matière de prix en particulier, ou était lacunaire comme pouvait le constater à propos des règles gouvernant les défenses anti-OPA. Aussi la réforme était-elle inévitable (...)" (BONNEAU, Thierry. La réforme 2006 des offres publiques d'acquisition. Droit des sociétés, Paris, n. 5, 2006, p. 5). Tradução livre: "Se o direito francês possuía regras bem estabelecidas sobre OPA, tais regras divergiam das comunitárias, em matéria de preço ou apresentavam lacunas sobre defesas anti-OPA. Nesse sentido, a reforma era inevitável (...)”.

${ }^{421}$ Idem, ibidem.

${ }^{422}$ Participação, segundo o dispositivo referido, de $1 / 3$ do capital social ou dos direitos de voto de uma sociedade francesa. 
essentiel de la société détentrice”. Em seguida, com a Lei no 2006-387, de 31 de março de 2006, houve mais do que a transposição do artigo $4^{\text {o }}$ da Diretiva $n^{\circ}$ 2004/25/CE, já que o artigo L. 433-1 do C. mon. fin foi completamente reformulado ${ }^{423}$.

Tal reformulação do artigo L. 433-1 do C. mon. fin. permitiu que fosse determinado, de forma expressa e clara, o âmbito de aplicação da legislação francesa referente às ofertas públicas de aquisição, bem como a da competência da AMF. O dispositivo em questão considera as diversas situações passíveis de serem verificadas, tais como: a) a companhia visada possui sua sede na França e os valores mobiliários de sua emissão são admitidos à negociação em mercado regulamentado francês. Aplica-se a regulamentação francesa e a competência é da $\mathrm{AMF}^{424}$; b) a companhia visada possui sua sede em um Estado-Membro da Comunidade Europeia ou em outro Estado-Membro do espaço econômico europeu, mas os valores mobiliários de sua emissão são admitidos à negociação em mercado regulamentado francês ${ }^{425}$. Aplica-se a regulamentação francesa e a competência é da AMF.

Houve, também, com a Lei $n^{\circ}$ 2006-387, de 31 de março de 2006, uma extensão do campo de aplicação da disciplina das ofertas públicas. Isso porque, diferentemente da Diretiva $n^{\circ}$ 2004/25/CE, que cuida apenas do mercado regulamentado, mencionada Lei trata, também, do mercado não regulamentado.

Diante disso, dispõe o artigo L. 433-1, IV, do C. mon. fin. que a disciplina das ofertas públicas se aplica aos mercados não regulamentados, desde que solicitado pela "personne qui le gère”. Trata-se, pois, de uma aplicação facultativa, que depende de solicitação específica.

\footnotetext{
${ }^{423}$ Assim ensina Thierry Bonneau a propósito do artigo L. 433-1 do C. mon. fin.: “(...) Ce texte a d'ailleurs été totalement réécrit et ne se borne pas à transposer les dispositions de l'article 4 de la directive (...): à la différence de celle-ci, qui concerne uniquement les marchés réglementés, il comporte également des dispositions relatives aux marchés non réglementés (...)" (BONNEAU, Thierry. La réforme 2006 des offres publiques d'acquisition. Droit des sociétés, Paris, n. 5, 2006, p. 6). Tradução livre: “(...) Esse texto foi totalmente reescrito e não se limita a transpor as disposições do artigo 4 da diretiva (...): diferentemente desta, que se refere unicamente aos mercados regulamentados, ele trata dos mercados não regulamentados (...)".

${ }^{424}$ Artigo L. 433-1, I, do C. mon. fin.

${ }^{425}$ Artigo L. 433-1, III, do C. mon. fin.
} 


\subsubsection{Informação e transparência das ofertas.}

Visando à melhora das informações concedidas aos acionistas e aos trabalhadores da companhia, conforme determinado, por exemplo, pelo artigo $3^{\circ}$ da Diretiva $n^{\circ}$ 2004/25/CE, a Lei nº 2006-387, de 31 de março de 2006, operou algumas mudanças.

Os administradores da companhia devem, quando da realização da assembleia geral, apresentar aos acionistas um relatório do qual conste elementos susceptíveis de exercer influência, no caso de oferta pública, tais como: a estrutura do capital social; as restrições estatutárias ao exercício do direito de voto e à transferência de ações ${ }^{426}$. A Lei $n^{\circ}$ 2006-387, de 31 de março de 2006, inovou, também, no que se refere à informação dos trabalhadores, a qual foi reforçada. A esse respeito é preciso indicar três inovações, conforme Thierry Bonneau:

\footnotetext{
"Si on néglige l'article L. 439-2 qui renvoie à l'article L. 432-1, il convient de retenir trois innovations: - le dispositif d'information ne concerne plus seulement les OPA et les OPE, mais l'ensemble des offres publiques d'acquisition; l'information ne bénéficie plus seulement au comité d'entreprise de la société cible, mais également au comité d'entreprise de l'auteur de l'offre; - et il est tenu compte de l'absence de comité d'entreprise; l'information doit alors être directement donnée aux membres du personnel (...) ${ }^{\text {,27 }}$.
}

Foi reforçada, também, a informação concedida à AMF e ao público, em geral. Isso porque além da declaração imposta pelo artigo L. 233-7 do C. com., tornou-se, também, obrigatória aquela do artigo L. 433-1, V, do C. mon. fin., a qual, de forma diversa da anteriormente mencionada, não está vinculada ao fato de ser atingido determinado percentual do capital social ou dos direitos de voto, mas ao fato de existirem motivos razoáveis que demonstrem que se prepara uma oferta pública de aquisição ${ }^{428}$.

\footnotetext{
${ }^{426}$ Artigo L. 225-100-3 do C. com.

${ }^{427}$ BONNEAU, Thierry. La réforme 2006 des offres publiques d'acquisition. Droit des sociétés, Paris, n. 5, 2006, p. 7. Tradução livre: "Se negligenciarmos o artigo L. 439-2, que faz remissão ao artigo L. 432-1, é preciso lembrar de três inovações: - o mecanismo de informação não se refere apenas às OPA e às OPE, mas ao conjunto de oferta pública de aquisição; - a informação não beneficia apenas o comitê de empresas da companhia visada, mas igualmente o comitê de empresas do ofertante; - no caso de ausência do comitê, a informação deve ser dada diretamente aos trabalhadores (...)".

${ }^{428}$ Idem, ibidem.
} 


\title{
5.3.3 Ação combinada.
}

A fim de adequar a legislação francesa à Diretiva $n^{\circ} 2004 / 25 / \mathrm{CE}^{429}$, que conceitua a ação combinada, na hipótese de oferta pública de aquisição, a Lei no 2006-387, de 31 de março de 2006, introduziu, no C. com., o artigo L. 233-10-1, o qual dispõe que, no caso de oferta pública de aquisição:

\begin{abstract}
“(...), sont considérées comme agissant de concert les personnes qui ont conclu un accord avec l'auteur d'une offre publique visant à obtenir le contrôle de la société qui fait l'objet de l'offre. Sont également considérées comme agissant de concert les personnes qui ont conclu un accord avec la société qui fait l'objet de l'offre afin de faire échouer cette offre" 430 .
\end{abstract}

\subsubsection{Técnicas de defesa contra oferta pública para aquisição do controle de companhia aberta hostil (artigos $9^{\circ}, 11$ e 12 da Diretiva $n^{\circ}$ 2004/25/CE).}

Como visto anteriormente, foi necessário, dentre outras medidas, um compromisso, materializado no artigo 12, para que a Diretiva $\mathrm{n}^{\circ}$ 2004/25/CE fosse adotada, já que muitos dos Estados-Membros não concordavam, principalmente, com o disposto nos artigos $9^{\circ}$ e 11 da Diretiva ${ }^{\circ}$ 2004/25/CE.

Em razão dos três dispositivos mencionados (artigos $9^{\circ}, 11$ e 12), o Ministro da Economia e das Finanças francês incumbiu Jean François Lepetit de criar um grupo de trabalho, através de carta datada de 18 de novembro de 2004, com o objetivo de analisar as possibilidades de transposição da Diretiva $n^{0}$ 2004/25/CE existentes e que mais favorecessem o crescimento e o emprego, na França.

O relatório elaborado pelo citado grupo de trabalho ("relatório Lepetit",431) foi entregue ao Ministro da Economia e das Finanças, no dia $1^{\circ}$ de julho de 2005, tendo sido recomendada a transposição do artigo $9^{\circ}$ da Diretiva $n^{\circ}$ 2004/25/CE, bem como a do artigo

\footnotetext{
${ }^{429}$ Artigo $2^{\circ}$ (1) da Diretiva ${ }^{\circ}$ 2004/25/CE.

430 Tradução livre: "são consideradas como tendo agido em conjunto as pessoas que concluíram um acordo com o ofertante, no caso de uma OPA. Igualmente, são consideradas como tendo agido em conjunto as pessoas que celebraram um acordo com a companhia visada, a fim de frustrar a oferta".

${ }^{431}$ Relatório datado de 27 de junho de 2005.
} 
12. No entanto, foi aconselhada a transposição parcial do artigo $11^{432}$, sobretudo, por significar um entrave à liberdade contratual ${ }^{433}$. O relatório Lepetit é descrito da seguinte forma por Didier Martin:

\begin{abstract}
"Le rapport Lepetit préconisait d'abord de transposer le principe de 'neutralité' des organes de direction et d'administration posé par l'article 9 de la directive OPA tout en réservant le jeu de l'exception de réciprocité; cette transposition constituant, selon le groupe de travail, un bénéfice en termes d'image de la France, la 'clause de réciprocité' permettant d'éviter que des sociétés qui n'appliquent pas la règle de passivité ne soient favorisées par rapport aux sociétés françaises qui y seraient assujetties. Il préconisait ensuite de ne transposer que partiellement les dispositions de l'article 11 qui lui ont paru disproportionnées eu égard aux objectifs poursuivis. En particulier, la transposition de ces dispositions aurait constitué, selon le groupe de travail, une 'entrave importante à la liberté contractuelle et pourrait priver investisseurs et entrepreneurs de solutions de financement et de contrôle flexibles" "434
\end{abstract}

O legislador francês seguiu as recomendações do relatório Lepetit ${ }^{435}$. De modo geral, o espírito da Lei $n^{\circ}$ 2006-387, de 31 de março de 2006, consistiu em reforçar as prerrogativas dos acionistas da companhia visada no que se refere à matéria ora analisada, em detrimento dos órgãos de administração ${ }^{436}$. Assim, a transposição da regra constante do artigo $9^{\circ}$ foi realizada no artigo L. 233-32 do C. com., localizando-se o mecanismo de reciprocidade (art. 12 da Diretiva ${ }^{\text {o }}$ 2004/25/CE) no artigo L. 233-33 do C. com. Dessa maneira, durante o período da OPA, os administradores devem, exceto com relação à procura de ofertas concorrentes, obter a aprovação prévia da assembleia geral para a

\footnotetext{
${ }^{432}$ Segundo Marie-Noëlle Dompé, o relatório recomendou a não transposição das disposições do artigo 11 aplicáveis no período da oferta. Assim o explica a autora a respeito do Relatório Lepetit: "Il recommandait en conséquence d'utiliser l'option ouverte par la directive de ne pas transposer les dispositions de l'article 11 applicables en période d'offre" (DOMPÉ, Marie-Noëlle, op. cit., p. 6). Tradução livre: "Ele recomendou, consequentemente, a utilização da opção constante da diretiva de não realizar a transposição das disposições do artigo 11 aplicáveis no período da oferta".

${ }^{433}$ Idem, p. 5.

${ }^{434}$ MARTIN, Didier; MOLFESSIS, Nicolas, op. cit., p. 573. Tradução livre: "O relatório Lepetit recomendou inicialmente a transposição do princípio de 'neutralidade' dos órgãos de direção e de administração estabelecido pelo artigo $9^{\circ}$ da diretiva OPA, sendo garantida a exceção de reciprocidade; essa transposição, segundo o grupo de trabalho, beneficiaria a imagem da França, sendo que a 'cláusula de reciprocidade' evitaria que as sociedades que não aplicassem a regra da passividade não fossem favorecidas com relação às sociedades francesas. Ele recomendou, ainda, a transposição parcial das disposições o artigo 11, que foram consideradas desproporcionais aos objetivos almejados. Em particular, a transposição de tais disposições poderia constituir, segundo o grupo de trabalho, um 'entrave substancial à liberdade contratual, podendo privar os investidores e empresários de soluções de financiamento e de controle flexíveis'”.

435 Idem, p. 575.

${ }^{436}$ BOMBRUN, Nicolas; MOULIN, Frédéric, op. cit., p. 23.
} 
adoção de qualquer medida que possa frustrar a oferta ${ }^{437}$. Ademais, qualquer delegação ${ }^{438}$ de uma medida suscetível de frustrar a oferta acordada pela assembleia geral antes do período da oferta pública deve ser suspensa durante a oferta ${ }^{439}$.

Vale salientar, como consta do mencionado artigo L. 233-33 do C. com., que a regra em questão sobre a autorização prévia somente se aplica no caso de haver reciprocidade, ou seja, ela não será aplicável, se o ofertante ou seu controlador direto ou indireto não a respeitar. Além disso, o mecanismo de reciprocidade autoriza tão somente os dirigentes a tomarem uma decisão suscetível de frustrar a oferta, sem que seja necessária a obtenção da aprovação da assembleia geral. Essa regra não autoriza, de modo algum, a violação dos poderes e das competências da assembleia geral ${ }^{440}$.

\footnotetext{
${ }^{437}$ Artigo L. 233-32, I, do C. com.

${ }^{438}$ Exceto, também, com relação à procura de outras ofertas.

${ }^{439}$ Artigo L. 233-32, III, al. 1, do C. com.

${ }^{440}$ Nesse sentido entende Alain Viandier: "En effet, la règle de réciprocité autorise seulement les dirigeants sociaux à prendre toute mesure dont la mise en œuvre est susceptible de faire échouer l'offre sans avoir à obtenir au préalable l'approbation de l'assemblée générale, elle ne leur permet pas de violer les pouvoirs propres de l'assemblée et de se substituer à elle pour décider une augmentation de capital (en dehors des cas de délégations), une réduction de capital, une fusion, (...), etc." (VIANDIER, Alain, op. cit., p. 327). Tradução livre: "Na verdade, a regra de reciprocidade, autoriza somente os administradores a adotarem medidas suscetíveis de frustrar a oferta sem a obtenção prévia da aprovação da assembleia geral, ela não permite a violação dos poderes próprios da assembleia geral, tampouco que se decida no seu lugar um aumento de capital (fora dos casos de delegações), uma redução do capital, uma fusão, (...), etc.”.
} 


\section{CONCLUSÃO}

O principal objetivo deste capítulo é expor quais os principais institutos do direito francês e europeu que poderiam ser adotados, após a devida adaptação à realidade nacional, pelo direito pátrio, bem como institutos deste que poderiam ser adotados por aquele. Não se trata de resumir o que já foi dito anteriormente para, enfim, chegar a uma conclusão.

Um ponto que merece ser disciplinado, no direito brasileiro, é a escalada em bolsa de valores. Deveria, como afirmado no estudo, ser obrigatória a realização de uma OPA $a$ posteriori, caso fosse atingido determinado percentual do capital social. Isso porque disciplinar adequadamente a escalada em bolsa de valores contribuirá para a consolidação do movimento de dispersão acionária mencionado.

O direito brasileiro deveria, ainda, aprimorar, como o fez o legislador francês, a obrigação de informação, tornando, por exemplo, obrigatória a realização de nova declaração, quando houver mudança no que tange ao objetivo.

Conforme analisado, o procedimento da OPA na França é caracterizado por uma presença marcante da AMF, além de ser necessário o registro prévio de todas as ofertas públicas, independentemente da modalidade, comprometendo a celeridade e aumentando o custo da operação. Isso poderia ser flexibilizado, tomando como exemplo o legislador brasileiro, que, acertadamente, como já mencionado, estabeleceu que, como regra, não há necessidade de registro prévio da OPA perante a CVM.

Considerando ser a OPA uma forma de aquisição originária do poder de controle, não há que se falar na realização da OPA a posteriori disciplinada no artigo 254-A da LSA. Ademais, considerando que não havia mecanismo que concedesse aos acionistas minoritários o direito de saída da companhia, o legislador brasileiro, de forma correta, abrangeu na reforma da Instrução CVM n ${ }^{\circ}$ 361/02, realizada pela Instrução CVM n ${ }^{\circ}$ 487/10, a questão dos acionistas minoritários, que não participaram da OPA. Assim, prevê o artigo 32-A que o ofertante, exceto no caso de OPA parcial, ficará obrigado a adquirir, 
após a OPA, as ações em circulação remanescentes da mesma espécie e classe, pelo prazo de 30 dias, contado da data da realização do leilão, pelo preço final da OPA.

O legislador francês se preocupou em conceder aos mencionados acionistas o direito de saída da companhia, seja pela reabertura da OPA, seja pela oferta pública de retirada. A reabertura da OPA pode gerar, além de custo para as partes envolvidas na operação, um aumento na sua duração, podendo contrariar o interesse social. Assim sendo, a legislação francesa poderia prever, em vez da reabertura da OPA, a simples obrigação de o ofertante adquirir as ações em circulação remanescentes, o que simplificaria o procedimento, tal como fez o brasileiro, no artigo 32-A da Instrução CVM no 361/02.

A adoção da figura do expert indépendant no direito brasileiro em situações de conflito de interesses seria importante, em razão da ruptura da igualdade entre os acionistas. Caberia ao legislador brasileiro, então, estabelecer lista exemplificativa das hipóteses em que seria necessária a designação do expert indépendant, bem como especificar sua função, sempre no sentido de apresentar uma opinião imparcial e independente sobre a OPA.

Com relação à transparência da oferta e à obrigação de informação, o legislador brasileiro poderia, a exemplo, do francês e europeu, exigir que fossem colocados no projeto de oferta os objetivos e a intenção do ofertante, para permitir uma adequada avaliação da oferta pelos acionistas destinatários e demais interessados ${ }^{441}$. E, a fim de garantir o interesse social, a exemplo do direito francês, seria relevante haver, no direito brasileiro, preocupação com a informação e participação dos empregados das companhias envolvidas na OPA, sendo necessária a imposição de sanções, no caso de descumprimento da obrigação prevista.

Considerando que, na França, o preço é, em princípio, livremente fixado pelo ofertante, como estudado, seria interessante que a legislação francesa adotasse dispositivos semelhantes aos da brasileira, de modo a evitar abusos e uma grande liberdade à AMF, no que se refere ao controle de preços.

${ }^{441}$ OIOLI, Erik Frederico. Oferta pública de aquisição do controle de companhias abertas. São Paulo: Quartier Latin, 2010, p. 224. 
Em relação às técnicas de defesa contra OPA hostil, sua aplicação não deveria, nas palavras de Erik Frederico Oioli, "proibir a transferência do controle de companhia visada”. Essa é a ideia que deve predominar no direito brasileiro. E é ela que predomina no direito francês, bastando verificar, por exemplo, a criação dos bônus de subscrição como mecanismo de defesa, pela Lei $n^{\circ}$ 2006-387, de 31 de março de 2006, bem como a questão da "neutralização das restrições" presente na Diretiva n' 2004/25/CE e no direito francês.

Com base na prática que o Brasil tem adquirido em tais operações, bem como no estudo de legislações estrangeiras, tem sido possível o aperfeiçoamento do direito pátrio, o que deve ser feito constantemente, tal como ocorrido com a Instrução CVM no 487/10.

O presente estudo contribuiu, assim, para análise de diversos aspectos da OPA, no direito brasileiro, no direito francês e na UE, e alguns pontos mereceram destaque para possível adaptação à realidade brasileira ou à estrangeira. 


\section{REFERÊNCIAS BIBLIOGRÁFICAS}

ADACHI, Vanessa; VALENTI, Graziella. Reformulação do segmento especial de governança na bolsa traz mudanças importantes para os minoritários. Valor Investe Valor Econômico, ano 6, n. 27, p. 12, abr. 2009.

ALBOUY, Michel; BONNET, Christophe. OPA, OPE et LBO. Paris: Economica, 2008.

ALVARES, Jefferson Siqueira de Brito. O atual conceito de valor mobiliário. Revista de Direito Mercantil, Industrial, Econômico e Financeiro, São Paulo, v. 142, 2006, p. 203 247.

ASCARELLI, Tullio. Problemas das sociedades anônimas e direito comparado. 2. ed. Campinas: Bookseller, 2001.

Iniciación al estudio del derecho mercantil, trad. it. de Evelio Verdera y Tulles. Barcelona: Bosch, 1964.

AUCKENTHALER, Franck. Droit des marchés de capitaux. Paris: L.G.D.J, 2004.

BAJ, Claude. Les modes de prise de contrôle. Revue de jurisprudence commerciale, Paris, n. 11, 1998, p. 35-42.

BEAUFORT, Viviane Mattei de. Acquis et limites de l'harmonisation communautaire en matière de prises de contrôle de sociétés par voie d'offres publiques d'acquisition, du point de vue de l'actionnaire minoritaire. Paris, 2001. Tese (Doutorado em direito). Université Paris I.

Les OPA en Europe. Paris: Economica, 2001.

BERLE JR., Adolf; MEANS, Gardiner. The modern corporation and private property. New York: Macmillan, 1940. 
BERTOLDI, Marcelo M. O poder de controle na sociedade anônima: alguns aspectos. Revista de Direito Mercantil, Industrial, Econômico e Financeiro, São Paulo, v. 118, 2000, p. 62-76.

BÉZARD, Pierre. Les offres publiques d'achat. Paris: Masson, 1982

BOITEAUX, Fernando Netto. Oferta pública de aquisição de controle de companhia aberta. Revista Forense, v. 84, n. 301, 1988, p. 53-72.

BOMBRUN, Nicolas; MOULIN, Frédéric. Défenses anti-OPA: le point après la loi "OPA" du 31 mars 2006. Revue trimestrielle de droit financier, Paris, n. 1, 2006, p. 19-26.

BONNEAU, Thierry; DRUMMOND, France. Droit des marchés financiers. 3. ed. Paris: Economica, 2010.

BONNEAU, Thierry. La réforme 2006 des offres publiques d'acquisition. Droit des sociétés, Paris, n. 5, 2006, p. 5-9.

BONNEAU, Thierry. Expertise indépendante. Droit des sociétés, Paris, n. 7, 2006, p. 31 35 .

BONNEAU, Thierry; FAUGÉROLAS, Laurent. Les offres publiques. Paris: EFE, 2005.

BONNEAU, Thierry. La réforme des offres publiques d'acquisition. Bulletin Joly, 1992, p. 599-606.

BOUTHINON-DUMAS, Hugues. Le droit des sociétés cotées. Paris: L.G.D.J, 2007.

BROCHIER, E; FRISON-ROCHE, M.A. Les décisions du CBV en matière d'offres publiques et le principe du contradictoire. Gaz. Pal., Paris, 29 octobre 1992, doct.

CAFRITZ, Eric; CARAMALLI, Delphine. La responsabilité des dirigeants de la société cible quant à leur prise de position sur l'offre envisagée. Recueil Dalloz, Paris, n. 2, 2004, p. $122-123$. 
CANIVET, Guy; MARTIN, Didier; MOLFESSIS, Nicolas (Org.). Les offres publiques d'achat. Paris: Litec, 2009.

CANTIDIANO, Luiz Leonardo. Direito societário \& mercado de capitais. Rio de Janeiro: Renovar, 1996.

Alienação e aquisição de controle. Revista de Direito Mercantil, Industrial, Econômico e Financeiro, São Paulo, v. 59, 1985, p. 56-67.

CARVALHOSA, Modesto. Oferta pública de aquisição de ações. Rio de Janeiro: IBMEC, 1979.

CHAMPAUD, Claude. Le pouvoir de concentration de la société par actions. Paris: Sirey, 1962.

CHARVÉRIAT, Anne; COURET, Alain; ZABALA, Bruno. Mémento pratique Francis Lefebvre: sociétés commerciales. Levallois-Perret: Francis Lefebvre, 2011.

CHARVÉRIAT, Anne. Mémento pratique Francis Lefebvre: cessions de parts et actions. Levallois-Perret: Francis Lefebvre, 2011.

Modification de la réglementation des offres publiques. Bulletin rapide de droit des affaires, Levallois-Perret, n. 1, 1999, p. 12-16.

CLERC, Christophe. Les bons d'offre au cœur de la transposition de la directive OPA. Revue trimestrielle de droit financier, Paris, n. 1, 2006, p. 27-33.

COMPARATO, Fábio Konder; SALOMÃO FILHO, Calixto. O poder de controle na sociedade anônima. 5. ed. Rio de Janeiro: Editora Forense, 2008.

COMPARATO, Fábio Konder. Direito empresarial - estudos e pareceres. São Paulo: Saraiva: 1990. 
Novos ensaios e pareceres de direito empresarial. Rio de Janeiro: Forense, 1981.

Aspectos jurídicos da macro-emprêsa. São Paulo: Revista dos Tribunais, 1970.

COHEN, Daniel. Vers la fin des offres publiques hostiles? In: Mélanges offerts à Paul Didier: études de droit privé. Paris: Economica, 2008, p. 125-138.

CONAC, Pierre-Henri. Les bons de souscription d'actions "Plavix" et les principes généraux des offres publiques. Revue des sociétés, Paris, n. 2, 2005, p. 321-337.

. L'offre publique d'acquisition conditionnelle. In: Droit bancaire et financier : mélanges AEDBF - France IV. Paris : Revue Banque Édition, 2004, p. 81-118.

COURET, Alain. OPA, les enjeux du nouveau cadre juridique. Revue Lamy: droit des affaires, Levallois-Perret, n. 15, 2007, p. 68-71.

COZIAN, Maurice; VIANDIER, Alain; DEBOISSY, Florence. Droit des sociétés. 25. ed. Paris: Litec, 2012.

DAIGRE, Jean-Jacques. Les offres publiques en bourse: aspects juridiques. Paris: Banque Éditeur, 2001.

DIDIER, Paul; DIDIER, Philippe. Droit commercial: les sociétés commerciales. t. 2. Paris: Economica, 2011.

DJEHANE, Youssef. Le calendrier des offres publiques. In: CANIVET, Guy; MARTIN, Didier; MOLFESSIS, Nicolas (Org.). Les offres publiques d'achat. Paris: Litec, 2009, p. 451-466.

DOMPÉ, Marie-Noëlle. La transposition de la directive OPA et les principes directeurs des offres. Droit des sociétés, Paris, n. 11, 2006, p. 5-10. 
DOUVRELEUR, Olivier. Offres publiques: typologie et caractères. In: CANIVET, Guy; MARTIN, Didier; MOLFESSIS, Nicolas (Org.). Les offres publiques d'achat. Paris: Litec, 2009, p. 337-377.

Un nouveau cas de retrait obligatoire: le retrait obligatoire dans la foulée d'une offre. Revue trimestrielle de droit financier, Paris, n. 3, 2006, p. 58-60.

DURUPT, Bertrand. La procédure d'offre publique devant l'Autorité des marchés financiers. In: CANIVET, Guy; MARTIN, Didier; MOLFESSIS, Nicolas (Org.). Les offres publiques d'achat. Paris: Litec, 2009, p. 15-32.

EIZIRIK, Nelson; GAAL, Ariádna B.; PARENTE, Flávia; HENRIQUES, Marcus de Freitas. Mercado de capitais regime jurídico. 2. ed. São Paulo: Renovar, 2008.

EIZIRIK, Nelson. Temas de direito societário. Rio de Janeiro: Renovar, 2005. . Sociedades anônimas - jurisprudência. Rio de Janeiro: Renovar, 1998.

Questões de direito societário e mercado de capitais. Rio de Janeiro: Forense, 1987.

FAUGÉROLAS, Laurent ; DUPONT-JUBIEN, André. Le rôle et les obligations des établissements présentateurs. In: CANIVET, Guy; MARTIN, Didier; MOLFESSIS, Nicolas (Org.). Les offres publiques d'achat. Paris: Litec, 2009, p. 493-515.

FAUGÉROLAS, Laurent. Les offres publiques de retrait et le retrait obligatoire. Bulletin Joly Bourse, Paris, 1999, p. 51-59.

FLEURIET, Michel. Les O.P.A. en France. Paris: Dalloz, 1991.

FRANCO, Vera Helena de Mello. Considerações sobre as ofertas públicas para aquisição de ações (OPAs): estado atual da questão. Revista de Direito Mercantil, Industrial, Econômico e Financeiro, São Paulo, v. 135, 2004, p. 16-57. 
FRISON-ROCHE, Marie-Anne. La prise de contrôle et les intérêts des associés minoritaires. Revue de jurisprudence commerciale, Paris, n. 11, 1998, p. 94-109.

GAVALDA, Christian. La réglementation de la cession des blocs de titres donnant le contrôle de sociétés dont les actions sont cotées ou placées hors cote: un essai de moralisation du processus de concentrationniste français. Revue de droit des affaires internationales, Paris, n. 8, 2002, p. 853-867.

GEORGES, Emmanuel. Essai de généralisation d'un droit de retrait dans la société anonyme. Paris: L.G.D.J, 2005.

GERMAIN, Michel (Org.) Les sociétés commerciales. t. 1. v. 2. 19. ed. Paris: L.G.D.J, 2009.

GILBERT, François. Harmonisation internationale et droit des offres publiques. Revue de droit des affaires internationales, Paris, n. 8, 2002, p. 853-867.

GODÉ, Pierre. Les intérêts des cocontractants (en cas de prise de contrôle d'une société). Revue de jurisprudence commerciale, Paris, n. 11, 1998, p. 118-133.

GRILLIER, Frédéric. Nouveau cadre législatif concernant les mesures de défense antiOPA. Enjeux et incertitudes. Inventaire des principales mesures \& nouveautés. Revue trimestrielle de droit financier, Paris, n. 3, 2006, p. 100-101.

GUNTHER, J. Ph.; GRIFFITH. Contrôle des concentrations de dimension communautaire em matière d'OPA. RJDA, 1992, p. 551.

HOUIN, Roger. La prise de contrôle d'une société par actions (à l'exclusion du contrôle des concentrations d'entreprise). Revue internationale de droit comparé, Paris, n. 2, 1986, p. 567-573.

HOVASSE, H. La fusion de sociétés dans la réforme des offres publiques d'acquisition. Dr. sociétés, n. 28, p. 1999. 
HUSSON, Bruno. La prise de contrôle d'entreprises. Paris: Presses Universitaires de France, 1987.

JOSUÁ, Adriana. Alienação do controle de S/A por oferta pública (art. 254-A da Lei das S/A). Revista de Direito Mercantil, Industrial, Econômico e Financeiro, São Paulo, v. 126, 2002, p. 141-157.

KLOEPFER-PELÈSE, Martine. Contribution à l'étude des offres publiques d'acquisition en droit français et américain: de l'attribution du pouvoir de décision au regard de l'analyse économique du droit. Paris, 2007. Tese (Doutorado em direito). Université Paris I.

LAMY FILHO, Alfredo; BULHÕES PEDREIRA, José Luiz. A Lei das S.A. t. III (Pareceres). v. 1. 2. ed. Rio de Janeiro: Renovar, 1996.

LAMY FILHO, Alfredo; BULHÕES PEDREIRA, José Luiz. A Lei das S.A. t. III (Pareceres). v. 2. 2. ed. Rio de Janeiro: Renovar, 1996.

LAPRADE, Frank Martin; GIULIANI, Guillaume. La réforme des offres publiques d'acquisition. Revue de droit bancaire et financier, n. 6, 2006, p. 55-68

LEÃES, Luiz Gastão Paes de Barros. Pareceres. v. 1 e 2. São Paulo: Singular, 2004.

Estudos e pareceres sobre sociedades anônimas. São Paulo: Revista dos Tribunais, 1989.

O conceito de security no direito norte-americano e o conceito análogo $\mathrm{n}$ direito brasileiro. Revista de Direito Mercantil, Industrial, Econômico e Financeiro, São Paulo, v. 41, 1974.

LE CANNU, Paul; DONDERO, Bruno. Droit des sociétés. 3. ed. Paris: Montchrestien, 2009. 
LE FUR, Anne Valérie. Les bons d'offre: une mesure de défense conforme au gouvernement d'entreprise. Bulletin Joly Bourse, Paris, 2007, p. 714-726.

LE MAUX, Julien. La protection des actionnaires minoritaires au sein des sociétés cotées françaises. Paris, 2003. Tese (Doutorado). Université Paris I.

LE NEBASQUE, Hervé. Les mesures de défense anti-OPA depuis la loi nº 2006-387 du 31 mars 2006. Revue des sociétés, Paris, n. 2, 2006, p. 237-280.

LOBO, Jorge. Interpretação realista da alienação de controle de companhia aberta. Revista de Direito Mercantil, Industrial, Econômico e Financeiro, São Paulo, v. 123, 2001, p. 7-22.

MARCILIO, Rodrigo. Oferta pública de aquisição de ações por alienação de controle acionário. São Paulo, 2006. Dissertação (Mestrado em Direito). Faculdade de Direito, Universidade de São Paulo.

MARÉCHAL, Anne; PIETRANCOSTA, Alain. Transposition de la Directive OPA: des incertitudes entourant le recours à la "clause de réciprocité". Bulletin Joly Bourse, Paris, 2005, p. 797-804.

MARTIN, Didier; MOLFESSIS, Nicolas. Offres publiques d'acquisition. Les mesures de défense anti-OPA. In: CANIVET, Guy; MARTIN, Didier; MOLFESSIS, Nicolas (Org.). Les offres publiques d'achat. Paris: Litec, 2009, p. 573-626.

MATTOS FILHO, Ary Oswald. O conceito de valor mobiliário. Revista de administração de empresas, Rio de Janeiro, n. 25, 1985, p. 37-51.

MENDONÇA, Jorge Ribeiro. A tomada da sociedade através de oferta pública de aquisição. Revista da Faculdade de Direito da Universidade de Lisboa, Lisboa, v. 45, n. $1 / 2$, p. $47-81$.

MELlO FILHO, Luiz Malcolm Mano de. Alienação de poder de controle nas sociedades anônimas no Brasil: a oferta pública de aquisição de ações obrigatórias 
decorrentes do artigo 254-A da Lei das S.A. São Paulo, 2008. Dissertação (mestrado em direito). Faculdade de Direito, Universidade de São Paulo.

MERLE, Philippe. Droit commercial: sociétés commerciales. 15. ed. Paris: Dalloz, 2012.

Droit commercial: sociétés commerciales. 14. ed. Paris: Dalloz, 2010.

Droit commercial: sociétés commerciales. 9. ed. Paris: Dalloz, 2003.

MOULIN, Jean-Marc. La loi $\mathrm{n}^{\circ}$ 2006-387 du 31 mars 2006 transposant la Directive OPA du 21 avril 2004. La semaine juridique - entreprise et affaires, Paris, n. 17, 2006, p. 757-765.

MULLER, Anne-Catherine. Droit des marchés financiers et droit des contrats. Paris: Economica, 2007.

NASCIMENTO, João Pedro Barroso do. Anotações sobre medidas defensivas à tomada de controle. São Paulo, 2010. Dissertação (Mestrado em Direito). Faculdade de Direito, Universidade de São Paulo.

NEUVILLE, Sébastien. Droit de la banque et des marchés financiers. Paris: Presses Universitaires de France, 2005.

NOVAES FRANÇA, Erasmo Valladão. Conflito de interesses nas Assembléias de S.A. São Paulo: Malheiros, 1993.

OHL, Daniel. Droit des sociétés cotées. 3. ed. Paris: Litec, 2008.

OIOLI, Erik Frederico. Oferta pública de aquisição do controle de companhias abertas. São Paulo: Quartier Latin, 2010.

PAILLUSSEAU, Jean. La société anonyme-technique d'organisation de l'entreprise. Paris: Sirey, 1967. 
PATELLA, Laura Amaral. Poder de controle. Seminário apresentado, em 31 de agosto de 2010, na disciplina DCO 5886 - Teoria geral do direito societário II, do curso de pósgraduação da Faculdade de Direito da Universidade de São Paulo.

PEREIRA, Guilherme Döring Cunha. Alienação do poder de controle acionário. São Paulo: Saraiva, 1995.

PETITPIERRE SAUVAIN, Anne. L'égalité des actionnaires dans l'offre publique d'achat. Revue de Droit des Affaires Internationales, n. 5, 1991, p. 645-657.

La cession de contrôle, mode de cession de l'entreprise. Genève: Université Georg, 1977.

Droit des sociétés et groupes de sociétés. Genève: Université Georg, 1972.

PIETRANCOSTA, Alain. Refonte des dispositions réglementaires relatives aux OPA. Revue trimestrielle de droit financier, Paris, n. 3, 2006, p. 4-14.

PLANIOL, Marcel ; RIPERT, Georges. Traité élémentaire de droit civil. v. 2. 11. ed. Paris: LGDJ, 1937.

PRADO, Roberta Nioac. Oferta pública de ações obrigatória nas S.A. São Paulo: Quartier Latin, 2005.

Da obrigatoriedade por parte do adquirente do controle de sociedade por ações de capital aberto de fazer simultânea oferta pública, em iguais condições, aos acionistas minoritários - art. 254 da Lei 6.404/76 e Resolução CMN 401/76 - é efetivo mecanismo de proteção aos minoritários? Revista de Direito Mercantil, Industrial, Econômico e Financeiro, São Paulo, v. 106, 1997, p. 83-105.

REFAIT, Michel. Rôle économique des offres publiques d'achat e d'échange. Paris, 1990. Tese (Doutorado em direito). Université Paris II. 
RIPERT, Georges; ROBLOT, René. Traité élémentaire de droit commercial. v. 1. 10. ed. Paris: LGDJ, 1976.

RIPERT, Georges; ROBLOT, René. Traité élémentaire de droit commercial. v. 2. 10. ed. Paris: LGDJ, 1976.

RONZANO, A. Offre publique d'achat d'actions non cotées. Revue de droit bancaire et de la bourse, Paris, 1993, p. 31-33.

SALOMÃO FILHO, Calixto. O novo direito societário. 3. ed. São Paulo: Malheiros, 2006.

Regulação e concorrência: estudos e pareceres. São Paulo: Malheiros, 2005.

Sociedade anônima: interesse público e privado. Revista de Direito Mercantil, Industrial, Econômico e Financeiro, São Paulo, n. 127, 2002, p. 7-20.

SALOMÃO FILHO, Calixto; RICHTER JÚNIOR; Mario Stella. Interesse social e poderes dos administradores na alienação de controle. Revista de Direito Mercantil, Industrial, Econômico e Financeiro, São Paulo, v. 89, 1993, p. 65-78.

SCHMIDT, Dominique. Les droits de minoritaires et les offres publiques. Recueil Dalloz, Paris, n. 27, 2007, p. 1887-1892.

Actualités du droit des offres publiques et de la sortie des minoritaires. Recueil Dalloz, Paris, 2005, p. 631-633.

Réflexions sur le retrait obligatoire. Revue de droit bancaire et de la bourse, Paris, n. 76, 1999, p. 213-216.

. Les définitions du contrôle d'une société. Revue de jurisprudence commerciale, Paris, n. 11, 1998, p. 9-14. 
SERVAN-SCHREIBER; GRUMBERG, A. W. Défenses anti-OPA, adoption de la directive européenne sur les OPA et enjeux pour les entreprises françaises. JCP E, 2007, p. 1218.

TEIXEIRA, Egberto Lacerda; GUERREIRO, José Alexandre Tavares. Das sociedades anônimas no direito brasileiro. v. 1 e 2. São Paulo: Bushatsky, 1979.

TEHRANI, Adrien. Les clauses de préemption et la directive 2004/25/CE du 21 avril 2004 concernant les offres publiques d'acquisition: contribution à l'étude des restrictions au transfert des titres de sociétés cotées. Paris, 2005. Mémoire d'admission DESS de droit des affaires - DJCE. Université Paris II. Disponível em <mjaparis2.webs.com/MEMOIRES\%202005/Adrien_TEHRANI.doc>. Acesso em 26.05.2011.

TROCHU, Michel. Nouvelles techniques de concentration. Montpellier: Librairies techniques, 1972.

. Les offres publiques d'achat. Revue trimestrielle de droit commercial et de droit économique, Paris, 1967, p. 699-717.

VALENTI, Graziella. À espera de uma oferta. Valor Econômico - EU\&Investimentos, 17 de agosto de 2011.

VAUPLANE, Hubert de; BORNET, Jean-Pierre. Droit des marchés financiers. 3. ed. Paris: Litec, 2001.

VERÇOSA, Haroldo Malheiros Duclerc. As cédulas de crédito bancário (CCBs) como valores mobiliários. Revista de Direito Mercantil Industrial, Econômico e Financeiro, v. 144, 2006, p. 120-127.

VIANDIER, Alain. OPA, OPE et autres offres publiques. 4. ed. Paris: Francis Lefebvre, 2010.

VU, Thi Thanh Van. Les offres publiques transfrontières. Paris, 2005. Tese (Doutorado em direito). Université Paris II. 
WALD, Arnoldo. Considerações sobre a aquisição e alienação de controle societário: o estudo da jurisprudência. Revista Forense, Rio de Janeiro, v. 89, n. 321, 1993, p. 3-12.

A oferta pública, a igualdade dos acionistas e o direito comparado. Revista de Direito Mercantil, Industrial, Econômico e Financeiro, São Paulo, v. 43, 1981, p. 1518 . 